This item was submitted to Loughborough's Research Repository by the author.

Items in Figshare are protected by copyright, with all rights reserved, unless otherwise indicated.

\title{
What determines sectoral trade in the enlarged EU?
}

PLEASE CITE THE PUBLISHED VERSION

LICENCE

CC BY-NC-ND 4.0

\section{REPOSITORY RECORD}

Marques, Helena, and Hugh Metcalf. 2019. "What Determines Sectoral Trade in the Enlarged EU?”. figshare. https://hdl.handle.net/2134/186. 
This item was submitted to Loughborough's Institutional Repository by the author and is made available under the following Creative Commons Licence conditions.

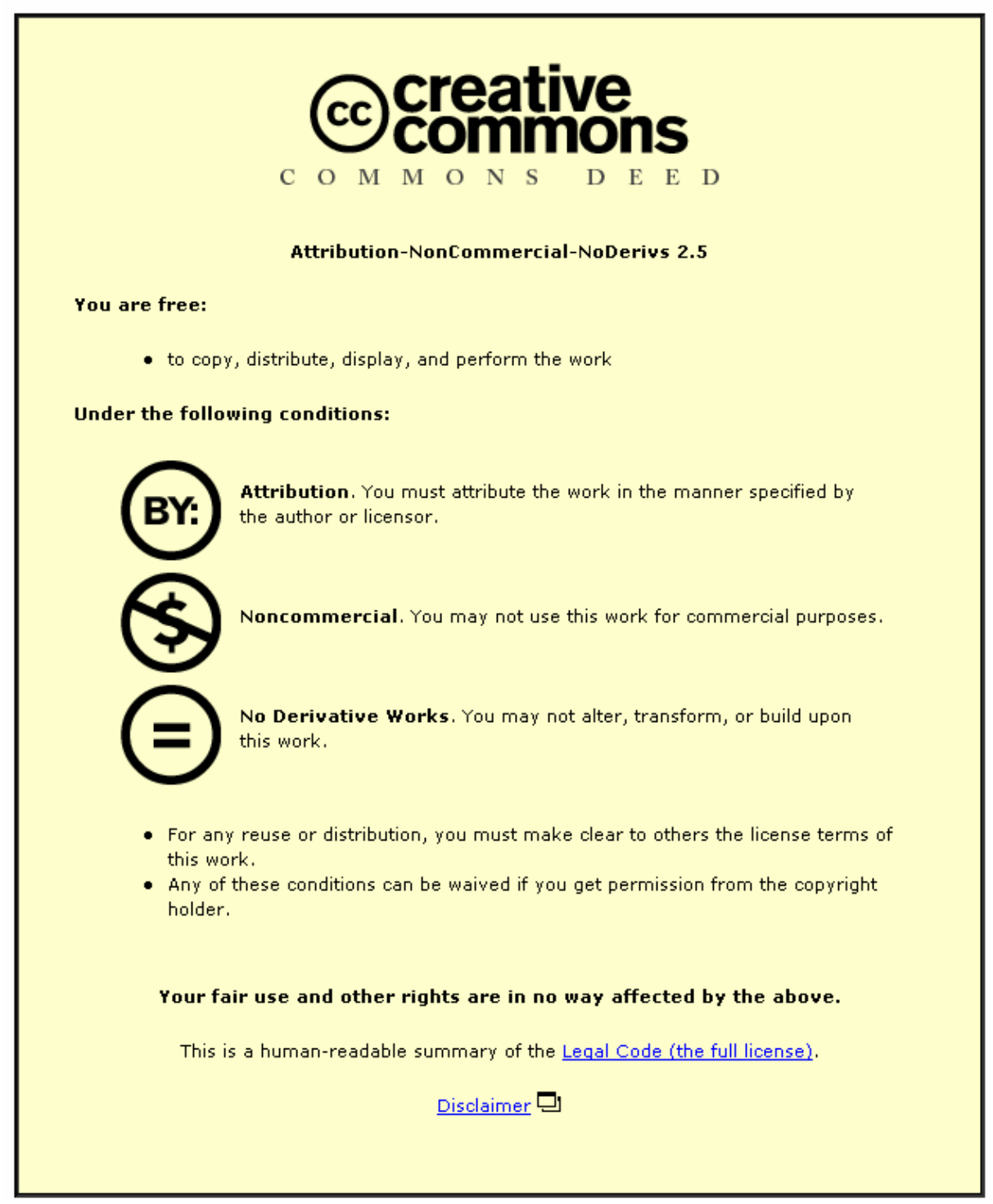

For the full text of this licence, please go to: http://creativecommons.org/licenses/by-nc-nd/2.5/ 
This item was submitted to Loughborough's Institutional Repository by the author and is made available under the following Creative Commons Licence conditions.

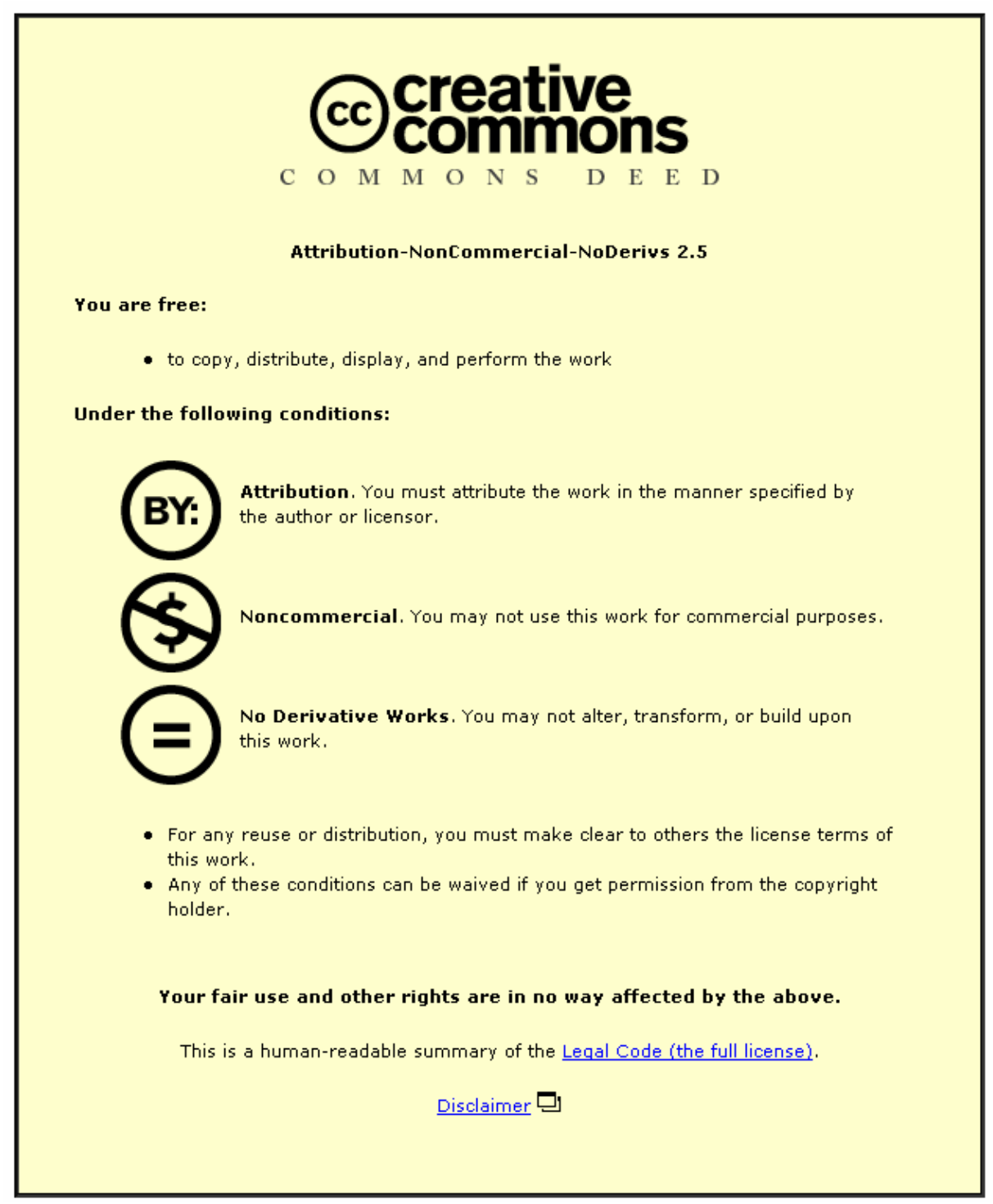

For the full text of this licence, please go to: http://creativecommons.org/licenses/by-nc-nd/2.5/ 


\title{
What Determines Sectoral Trade in the Enlarged EU? ${ }^{\boxminus}$
}

\author{
Helena Marques (Loughborough University, UK) \\ Hugh Metcalf (Newcastle University, UK)
}

September 2003

\begin{abstract}
In this paper we estimate a sectoral gravity model for trade within a heterogeneous trade bloc, the enlarged EU, comprised of a high-income group (wealthiest EU), a middle-income group (Greece, Portugal and Spain), and a low-income group (acceding Central and Eastern European countries). The estimation was conducted on sectors with different degrees of scale economies and skill-intensities in the presence of transport costs. The results offer support for the call to incorporate trade theories based on both endowments and scale economies. In addition, whilst integrating poorer countries is beneficial for all of the participants in the bloc, there is still a role for redistribution policy. However, the EU's Regional Policy, for example, should not be individual initiatives but should be a mix of policies, focussing on both income and education/skills, together with infrastructure development.
\end{abstract}

Keywords: gravity model, trade, human capital, EU enlargement JEL: F1, L6

\footnotetext{
"Acknowledgements: We gratefully acknowledge the valuable comments of the participants in a seminar at the University of Newcastle-upon-Tyne, the 2003 EEFS Conference (University of Bologna, Italy) and the 2003 ETSG Conference (University Carlos III, Spain). Any remaining errors are our full responsibility.

Corresponding author: Helena Marques, Department of Economics, Sir Richard Morris Building, Loughborough University, Loughborough LE11 3TU, UK, tel.: +44 1509222 704, fax: +44 1509223 910, email: $\underline{\text { H.I.Marques@lboro.ac.uk }}$
} 

The globalisation phenomenon has been accompanied by a great deal of regionalisation, whereby countries have joined regional trade blocs with varying degrees of heterogeneity. Two of the most important regional trade blocs, the NAFTA in the American continent and the EU in the European continent, integrate countries at different levels of development. In the case of the EU, such heterogeneity will be aggravated with the Eastern enlargement, scheduled to take place in one year's time. Ten countries will become members of what is already one of the largest trade blocs in the world and two more (Bulgaria and Romania) may be admitted by 2007. Except for the Mediterranean islands of Cyprus and Malta, the new members will be Central and Eastern European Countries (CEECs) ${ }^{\square}$, in a more or less advanced stage of economic transition. During the transition process, started in these countries more than a decade ago, East-West trade has been progressively liberalised under the Europe Agreements signed between the EU and each of the CEECs. However, such liberalisation has not produced uniform results either at the country or at the sectoral level. More specifically, not only the CEECs have been trading far more with the richer than with the poorer current EU members, but also the Europe Agreements sheltered the so-called sensitive sectors from liberalisation (Baldwin 1994).

Given the different characteristics of the countries and sectors involved in the liberalisation process, we can expect trade in heterogeneous industrial sectors within a heterogeneous EU-25 to be determined differently. Thus it is the aim of this paper to study the relative importance of different determinants of trade, such as location and endowments, in shaping the trade patterns of a heterogeneous trade bloc, exemplified by the post-enlargement EU. This is done by estimating a gravity model of trade flows between country groups with different skilled/unskilled labour ratios and different spatial and non-spatial trade costs, in sectors with different degrees of economies of scale and skill-intensity. We think of the enlarged EU as constituted of

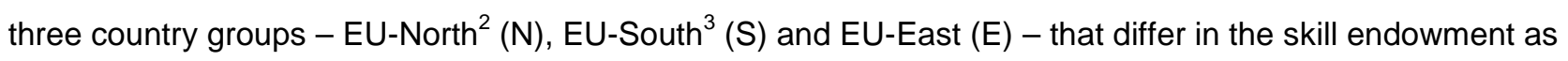
well as both spatial and non-spatial trade costs. The latter are compressed to zero when $\mathrm{E}$ integrates with $\mathrm{N}$ and $\mathrm{S}$, but the former persist and give rise to a hub effect. In $_{\text {In }}$ this set-up, $\mathrm{N}$ is a hub and has a higher skill endowment, this is, more skilled workers per capita, than the two peripheries $S$ and E. Following the EU's Eastern enlargement, the different locational and endowment advantages of the three country groups considered can be expected to influence the location of sectors with different degrees of economies of scale and skill intensity, this is, different skilled/unskilled labour ratio. The location of different sectors will in turn determine the sectoral net exports of each country group. The three country groups can also be characterised in terms of their stages of development, with $\mathrm{N}$ being the most developed, followed by $\mathrm{S}$ and $\mathrm{E}$ the least developed.

\footnotetext{
${ }^{1}$ In the paper we refer to CEECs, or alternatively to EU-East, as being the group formed by Czech Republic, Estonia, Hungary, Latvia, Lithuania, Poland, Slovak Republic, Slovenia, and, on the assumption that they will effectively join the EU, Bulgaria and Romania.

${ }^{2}$ We define EU-North as the group formed by all EU-15 countries except Greece, Portugal and Spain.

${ }^{3}$ We define EU-South as the group formed by Greece, Portugal and Spain.

${ }^{4}$ The hub effect was introduced by Krugman (1993) in a three country model: a country is said to be a hub if the spatial trade costs between itself and each of the two other countries are lower than the spatial trade costs between the latter two.
} 
The relative role of endowments and location in determining trade patterns has been a subject of debate in

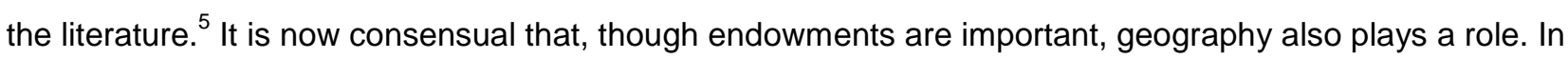
particular, by increasing transport costs, an unfavourable geographical location can significantly explain international inequalities, as shown by Limao and Venables (2001), Redding and Venables (2001), Venables (2001). Earlier cross-section studies focussing on East-West trade, such as Havrylyshyn and Pritchett (1991), Hamilton and Winters (1992), Winters and Wang (1992), also concluded that geographical distance was a main determinant of East-West trade. These studies used a simple aggregate gravity model, later improved by using only EU and CEEC data to compute the gravity parameters (Fidrmuc 1998, Buch and Piazolo 2000), by modifying the gravity model to either incorporate Krugman's (1991) assumption that proximity increases trade because it decreases transport costs (Maurel and Cheikbossian 1998) or by incorporating both geographical and economic distances (Vittas and Mauro 1997). In addition, Nilsson (2000) is the only study after Baldwin (1994) that has into account each of the EU-15 countries. All others look exclusively at EastNorth trade.

We improve on these previous empirical studies in several ways. First, the length of the transition period and the enforcement of the Europe Agreements provide data that is a better indicator of normalised trade patterns than the pre-transition, pre-liberalisation data used in most of the earlier studies. Second, we believe our sectoral approach to be innovative since most previous studies were conducted at an aggregate level. In fact, we find that the determinants of trade can differ greatly across sectors with different characteristics. Third, we use panel data that accounts for sources of heterogeneity and idiosyncrasy, producing unbiased results, as shown by Matyas (1997, 1998), Breuss and Egger (1999). We take this further by using the Prais-Winsten regression with Panel-Corrected Standard Errors (PCSEs). To the best of our knowledge this is the first time PCSEs are used in the study of trade patterns between the member countries of an enlarged EU. This method incorporates the assumption that the disturbances are heteroskedastic (each country has its own variance) and contemporaneously correlated across countries (each pair of countries has their own covariance). This assumption seems to be especially suited for any study involving transition economies.

Our main findings can be summarised as follows. First, even though Spain is simultaneously the largest and richest country in the Southern group, its size and income have not significantly enhanced its trade with the East during the 1990s when compared to Portugal and Greece. Second, for the centre (North) size is a more important determinant of trade than income, whereas exactly the opposite is true for the Southern and Eastern peripheries, supporting the argument on the relevance of catching-up in boosting trade. Third, economic distance increases centre-periphery trade, but decreases periphery-periphery trade. Fourth, human capital endowments increase Eastern trade but decrease Southern trade. Generally, North-South trade is more determined by incomes than by endowments and it is likely to remain so. On the contrary, as Eastern incomes start rising, it is likely that the importance of endowments in North-East trade will increase. Fifth, the distance effects are very negative for the peripheries. When we control for differences in endowments, distance becomes less important as the former provide another motive for trade. Thus if the advantage in

\footnotetext{
${ }^{5}$ Davis (2000) summarises the issue.
} 
endowments is strong enough it may compensate for a disadvantage in market access. Finally, trade in sectors with high economies of scale is very much determined by country size, whereas income and human capital are especially important in sectors with high skill-intensity, though generally not relevant in low scale economies, low skill-intensity sectors. This result is robust to their interaction with distance. The Europe Agreements have been especially beneficial for trade in high scale economies sectors, whereas being a Euro zone country tends to have a higher impact on high-skill sectors.

The sectoral approach also highlights the importance of history. The South has traditional strengths in the low skill and low economy of scale sectors and despite rising incomes remains focused on these areas. The East, as the poorest group, can exploit its comparative advantage in human capital endowments with the south, and benefit by focusing on the higher skill sectors. The results also emphasise that all country groups benefit from integration and from an increase in the level of income or human capital endowments of their neighbours as a substantial pull through effect is found. In policy terms this paper offers support for the integration of poorer countries into regional trading blocs. It further supports the policy of supporting the income of the poorest regions provided that this is linked to investment in education and infrastructure.

The paper is organised as follows. Section 2 presents the gravity model specifications. Section 3 examines the estimation results. Section 4 concludes.

\section{A Sectoral Gravity Model}

In this section we present the four alternative gravity equations that are the basis of our empirical study. Our benchmark equation keeps the two main hypotheses behind the gravity model. The first main hypothesis is that the volume of trade is directly related to the market size of the trading partners, here proxied by their population (POP), and inversely related to the physical distance between them (DIST). The second main hypothesis is that the volume of trade is a function of country wealth, as measured by GDP per capita (GDPPC). This second element represents more faithfully the so-called Linder (1961) hypothesis on the importance of demand structure and preferences in a world of differentiated goods. High-income countries consume high-quality goods and low-income countries consume low-quality goods. Thus the quality content of exports and imports should increase with GDP per capita.

The two main gravity hypotheses are augmented in two ways. First, the source of quality is the human capital endowment that differs across countries. Thus we add the partner countries' skilled/unskilled labour ratio (HKPC), proxied by the fraction of the country's population with tertiary education studies. Countries relatively abundant in human capital are expected to be net exporters of skill-intensive goods and countries relatively poor in human capital are expected to be net importers of such goods. Second, we distinguish between spatial and non-spatial trade barriers. Spatial trade barriers are given by physical distance and a common border dummy (BORDER). The non-spatial trade barriers are dealt with by means of time dummies, one for 
EURO membership and another controlling for progressive trade liberalisation with the East since 1991 under the enforcement of the Europe Agreements (EA). Accordingly, our benchmark specification of the gravity model to be estimated for exports and imports of sector $k$ products between countries $i$ and $j$ in year $t$ takes the form:

$$
\begin{aligned}
\text { TRADE }_{\mathrm{ijt}}^{\mathrm{k}}= & \text { POP }_{\mathrm{it}} \beta_{1}+\mathrm{POP}_{\mathrm{jt}} \beta_{2}+\mathrm{GDPPC}_{\mathrm{it}} \beta_{3}+\mathrm{GDPPC}_{\mathrm{jt}} \beta_{4}+\mathrm{HKPC}_{\mathrm{it}} \beta_{5}+\mathrm{HKPC}_{\mathrm{jt}} \beta_{6}+ \\
& +\operatorname{DIST}_{\mathrm{ij}} \beta_{7}+\mathrm{BORDER}_{\mathrm{ij}} \beta_{8}+\mathrm{EA}_{\mathrm{ijt}} \beta_{9}+\mathrm{EURO}_{\mathrm{ijt}} \beta_{10}+\mathrm{u}_{\mathrm{ijt}}^{\mathrm{k}}
\end{aligned}
$$

We modify equation (1) by interacting the skilled/unskilled labour ratio with both the partners' GDPs per capita and the physical distance between partners. The first interaction crosses demand with supply factors. It can be read as representing differences in the skill endowment controlling for similar levels of quality consumption, or alternatively as representing differences in quality consumption for similar levels of skill endowment. The interaction of the skilled/unskilled labour ratio with distance proxies for knowledge spillovers that decrease with distance between countries and provides another reason why distance can negatively influence trade. The second specification is as follows:

$$
\begin{aligned}
\text { TRADE }_{i j t}^{k}= & \text { POP }_{i t} \beta_{1}+\text { POP }_{\mathrm{jt}} \beta_{2}+\left(\text { GDPPC }_{\mathrm{it}}{ }^{*} \mathrm{HKPC}_{\mathrm{it}}\right) \beta_{3}+\left(\mathrm{GDPPC}_{\mathrm{jt}}{ }^{*} \mathrm{HKPC}_{\mathrm{jt}}\right) \beta_{4}+ \\
& +\left(\mathrm{DIST}_{\mathrm{ij}}{ }^{*} \mathrm{HKPC}_{\mathrm{it}}\right) \beta_{5}+\left(\mathrm{DIST}_{\mathrm{ij}}{ }^{*} \mathrm{HKPC}_{\mathrm{jt}}\right) \beta_{6}+\mathrm{BORDER}_{\mathrm{ij}} \beta_{7}+\mathrm{EA}_{\mathrm{ijt}} \beta_{8}+\mathrm{EURO}_{\mathrm{itt}} \beta_{9}+\mathrm{u}_{\mathrm{ijt}}^{\mathrm{k}}
\end{aligned}
$$

An alternative to equations (1) and (2) is to replace the GDP per capita and the skilled/unskilled labour ratio of each country with the absolute value of the difference between them. To these variables we call respectively economic distance (ECDIST) and human capital distance (HKDIST). The impact of economic distance on trade is a test for intra versus inter-industry trade. Following the Linder (1961) hypothesis, in a world of intra-industry trade we expect countries with similar demand structures to trade more. As a consequence, if economic distance decreases trade we are in the presence of the intra-industry type, whereas if it increases trade then the inter-industry type is predominant. The impact of human capital distance on trade is a test for the HOS hypothesis according to which trade increases with differences in endowments. The modified models are as follows:

$$
\begin{aligned}
& \text { TRADE } E_{i j t}^{k}=\text { POP }_{i t} \beta_{1}+\text { POP }_{\mathrm{jt}} \beta_{2}+\mathrm{ECDIST}_{\mathrm{ijt}} \beta_{3}+\mathrm{HKDIST}_{\mathrm{t}} \beta_{4}+ \\
& +\operatorname{DIST}_{\mathrm{ij}} \beta_{5}+\mathrm{BORDER}_{\mathrm{ij}} \beta_{6}+\mathrm{EA}_{\mathrm{ijt}} \beta_{7}+\mathrm{EURO}_{\mathrm{ijt}} \beta_{8}+\mathrm{u}_{\mathrm{ijt}}^{\mathrm{k}} \\
& \text { TRADE } E_{\mathrm{ijt}}^{\mathrm{k}}=\mathrm{POP}_{\mathrm{it}} \beta_{1}+\mathrm{POP}_{\mathrm{jt}} \beta_{2}+\left(\mathrm{ECDIST}_{\mathrm{ijt}}{ }^{*} \mathrm{HKDIST}_{\mathrm{ijt}}\right) \beta_{3}+ \\
& +\left(\text { DIST }_{i j}{ }^{*} \mathrm{HKDIST}_{\mathrm{ijt}}\right) \beta_{5}+\mathrm{BORDER}_{\mathrm{ij}} \beta_{6}+\mathrm{EA}_{\mathrm{ijt}} \beta_{7}+\mathrm{EURO}_{\mathrm{ijt}} \beta_{8}+\mathrm{u}_{\mathrm{ijt}}^{\mathrm{k}}
\end{aligned}
$$

In specifications (1) and (2) we included the income levels and human capital endowments of each of the partner countries, either separately or interacted. Thus it matters how much of income and endowment each country has. In specifications (3) and (4) we consider the differences in income levels and human capital 
endowments, again separately or interacted. Now it matters how different countries are, irrespective of being richer or poorer, more or less endowed.

\section{Estimation Results}

We use equations (1)-(4) to study the relative importance of different determinants of trade, such as location and endowments, in shaping the trade patterns of a heterogeneous trade bloc, exemplified by the postenlargement EU. This bloc contains a high-income group, EU-North (N), a middle-income group, EU-South (S), and a low-income group, EU-East (E). The three groups differ in the skill endowment as well as both spatial and non-spatial trade costs. In this framework, $\mathrm{N}$ is a hub and has a higher skill endowment, this is, more skilled workers per capita, than the two peripheries $\mathrm{S}$ and $\mathrm{E}$. Sectors also differ in their characteristics, namely economies of scale and skill-intensity. As $\mathrm{N}$ has better access to markets and suppliers, as well as more skilled workers, it has a double advantage in sectors with high degree of scale economies and high skill-intensity, also producing higher quality products. On the contrary, the peripheries ( $\mathrm{S}$ and $\mathrm{E}$ ) compete in low scale economies, low skill-intensity sectors. However, they can shift to either high scale sectors if capital is supplied by FDI or to high skill sectors if their human capital endowments increase.

We estimate equations (1) (4) for bilateral trade flows between the three possible pairs - North-East (N-E), North-South (N-S) and South-East (S-E) - for four groups of sectors distinguished by degree of economies of scale as in Pratten (1988) and skill-intensity as in Baldwin et al. (2000). These four groups are as follows: Chemicals, Machinery and Transport Equipment are high scale economies and high skill-intensive, Metals are high scale economies and low skill-intensive, Leather \& Footwear, Minerals and Textiles \& Clothing are low scale economies and low skill-intensive, and Wood Products are low scale economies and high skillintensive. A full description of the data sources is provided in Appendix A.

Estimation of equations (1) (4) is carried out through the Prais-Winsten regression with correlated Panel Corrected Standard Errors (PCSEs), which assumes that the disturbances are heteroskedastic (each country has its own variance) and contemporaneously correlated across countries (each pair of countries has their own covariance). On the whole the results are robust to the change in estimation method, the differences being mostly in the standard errors. In this section we present the coefficients and p-values obtained through each model specification and show the full estimation results in Appendix $B$. The regression coefficients and $p$-values are given in Tables 1 to 13 for the different country groups and sectors considered.

\footnotetext{
${ }^{6}$ The coefficients and p-values shown are averages across model specifications in the case of variables common to more than one specification. For example, population and border are present in all four models and thus we take the average of the coefficients obtained in each of them.
} 
As shown in Table 1, market size has on average a positive impact on trade. Strictly, we can talk of home market effects when trade increases more than proportionally with the home market size, this is, when the size coefficient is larger than one. The home market effect seems to be especially related to the sectoral degree of economies of scale, as home market effects tend to be higher in

\begin{tabular}{|c|c|c|c|c|c|c|}
\hline \multicolumn{7}{|c|}{ Table 1: Home market effects } \\
\hline & & & $\begin{array}{c}\text { High scale } \\
\text { economies and } \\
\text { high skill-intensity }\end{array}$ & $\begin{array}{c}\text { High scale } \\
\text { economies and } \\
\text { low skill-intensity }\end{array}$ & $\begin{array}{c}\text { Low scale } \\
\text { economies and } \\
\text { high skill-intensity }\end{array}$ & $\begin{array}{l}\text { Low scale } \\
\text { economies and } \\
\text { low skill-intensity }\end{array}$ \\
\hline \multirow{4}{*}{$N-E$} & & Exports & $1.190^{* * *}$ & $1.153^{* * *}$ & $1.144^{* * *}$ & $1.489^{* * *}$ \\
\hline & & Imports & $1.238^{\star \star \star}$ & $1.562^{\star \star \star}$ & $1.149^{\star \star \star}$ & $1.123^{\star \star \star}$ \\
\hline & $\mathrm{F}$ & Exports & $1.409^{* * *}$ & $1.303^{* \star *}$ & $0.931^{* \star *}$ & $1.088^{* \star *}$ \\
\hline & & Imports & $1.003^{\star \star \star}$ & $1.110^{\star \star \star}$ & $0.700^{\star \star \star}$ & $0.890^{* * *}$ \\
\hline \multirow{4}{*}{ N-S } & & Exports & $1.266^{\star \star *}$ & $1.495^{\star \star \star}$ & $1.277^{\star \star \star}$ & $1.276^{\star \star \star}$ \\
\hline & $\mathbf{N}$ & Imports & $1.229^{\star \star \star}$ & $1.032^{\star \star \star}$ & $0.997^{\star \star \star}$ & $1.099^{\star \star \star}$ \\
\hline & s & Exports & 1.598 & $1.482^{\star \star \star}$ & $0.938^{*}$ & $0.281^{* *}$ \\
\hline & & Imports & 0.676 & $1.357^{* \star *}$ & $1.025^{*}$ & 0.111 \\
\hline \multirow{4}{*}{ S-E } & & Exports & 2.080 & $0.670^{*}$ & 1.123 & 0.663 \\
\hline & s & Imports & 0.815 & 0.521 & $1.409^{*}$ & 1.100 \\
\hline & $F$ & Exports & $1.579^{* * *}$ & $1.695^{\star \star *}$ & $0.954^{* * *}$ & $1.009^{* * *}$ \\
\hline & & Imports & $0.841^{*}$ & $1.143^{* * *}$ & 0.469 & $0.962^{* * *}$ \\
\hline
\end{tabular}
sectors with higher economies of scale. With respect to countries, we must distinguish centre-periphery from periphery-periphery trade. Home market effects are generally more important for EU-North than for either the Southern or Eastern peripheries, which would be expected given EU-North's position as centre. Though the two largest coefficients occur in periphery-periphery trade, more specifically in Eastern exports of products from high scale economies sectors to EU-South, size is mostly not significant for periphery-periphery trade with the East, this is, Spain does not significantly trade more with the East than Portugal or Greece. This could be due to Spain's lower openness to trade in general that carries over to trade with the East.

Our measure of income (GDP per capita) is positive and significant most of the time (Table 2). Thus richer countries tend to register a higher value of exports and imports. As argued before, income determines both the supply of and the demand for quality. Thus countries with higher income have the means to produce high quality products and also have a higher preference for quality

\begin{tabular}{|c|c|c|c|c|c|}
\hline \multicolumn{6}{|c|}{ Table 2: Income effects } \\
\hline & & $\begin{array}{c}\text { High scale } \\
\text { economies and } \\
\text { high skill-intensity }\end{array}$ & $\begin{array}{c}\text { High scale } \\
\text { economies and } \\
\text { low skill-intensity }\end{array}$ & $\begin{array}{c}\text { Low scale } \\
\text { economies and } \\
\text { high skill-intensity }\end{array}$ & $\begin{array}{l}\text { Low scale } \\
\text { economies and } \\
\text { low skill-intensity }\end{array}$ \\
\hline \multirow{4}{*}{$\mathrm{N}-\mathrm{E}$} & Exports & $2.132^{\star \star \star}$ & $2.819^{* * *}$ & $1.753^{\star \star \star}$ & 1.169 \\
\hline & Imports & 1.338 & $1.681^{* * *}$ & $2.867^{\star * \star}$ & 1.236 \\
\hline & Exports & $1.728^{\star * *}$ & $1.264^{* * *}$ & $0.890^{\star * *}$ & 0.687 \\
\hline & Imports & $0.885^{\star * *}$ & $0.958^{* * *}$ & $0.510^{\star * *}$ & $0.532^{*}$ \\
\hline \multirow{4}{*}{ N-S } & Exports & $0.638^{*}$ & $1.775^{\star * *}$ & $3.344^{* * *}$ & $1.334^{* *}$ \\
\hline & Imports & 1.203 & $0.450^{*}$ & $1.162^{* *}$ & 1.728 \\
\hline & Exports & $8.861^{* * *}$ & $0.561^{\star * *}$ & $7.733^{\star \star *}$ & $4.022^{*}$ \\
\hline & Imports & $3.912^{* * *}$ & -0.219 & $2.867^{\star}$ & 1.186 \\
\hline \multirow{4}{*}{ S-E } & Exports & 7.703 & $11.483^{\star * *}$ & 7.394 & $9.298^{\star *}$ \\
\hline & Imports & 4.195 & 4.652 & $6.416^{\star * *}$ & 6.805 \\
\hline & Exports & $1.553^{* \star *}$ & $1.251^{* * *}$ & $1.488^{* * *}$ & 0.625 \\
\hline & Imports & $1.063^{\star \star \star}$ & 0.206 & $0.964^{* * *}$ & 0.711 \\
\hline
\end{tabular}
products. As we control for size, which determines the volume of international trade, the income effects will determine mostly the prices of goods, which are a proxy for quality. As a consequence, we conclude that the quality of the goods traded also increases with the income of the trading partners. Interestingly, the most 
sizeable significant effects occur in EU-South's trade with both North and East. Thus, an increase in the income of countries like Greece, Portugal and Spain would substantially increase the quality of the products they trade with the rest of the EU. In addition, whereas for the centre size is a more important determinant of trade than income, exactly the opposite is true for the two peripheries, supporting the argument on the relevance of catching-up in boosting trade. Furthermore, by increasing the South's income the rest of the EU would benefit from a pull-through effect in trade.

Income effects are especially noticeable in sectors with high skill-intensity, as would be expected, though two of the highest mean coefficients show in sectors with low skill-intensity, more exactly in Southern exports to the East. The issue here would be one of product upgrading within the same sectors. As expected, income is generally not relevant in low scale economies, low skill-intensity sectors. In addition, income does not matter in determining trade in high scale economies, high skill-intensity in two instances. First, the imports of Northern countries from East and South do not depend on their incomes. This can be explained by thinking that the preference for quality depends on income. Thus, if the quality of imports is relatively low, all Northern countries would be equally driven to demand them, as the bottom quartiles of income are at a similar level and the top quartiles are the main responsible for overall income differences. The second case of insignificance relates to Southern trade with the East. Spain is simultaneously the largest and richest country in the Southern group. Thus the income and the size results are similar: Spain's size and income have not significantly enhanced its trade with the East during the 1990s with respect to Portugal and Greece.

Human capital endowments would be expected to influence trade as follows: countries relatively abundant in human capital are expected to be net exporters of skillintensive goods and countries relatively poor in human capital are expected to be net importers of such goods. In Table 3, the magnitude and significance of the endowment effects are more related to the countries involved than to the

\begin{tabular}{|c|c|c|c|c|c|}
\hline \multicolumn{6}{|c|}{ Table 3: Endowment effects } \\
\hline & & $\begin{array}{c}\text { High scale } \\
\text { economies and } \\
\text { high skill-intensity }\end{array}$ & $\begin{array}{c}\text { High scale } \\
\text { economies and } \\
\text { low skill-intensity }\end{array}$ & $\begin{array}{c}\text { Low scale } \\
\text { economies and } \\
\text { high skill-intensity }\end{array}$ & $\begin{array}{c}\text { Low scale } \\
\text { economies and } \\
\text { low skill-intensity }\end{array}$ \\
\hline \multirow{4}{*}{$N-E$} & Exports & $0.458^{\star \star}$ & 0.114 & $1.170^{\star \star \star}$ & 0.180 \\
\hline & Imports & $0.793^{* *}$ & $0.793^{\star \star \star}$ & $1.191^{\star \star \star}$ & 1.264 \\
\hline & Exports & 1.120 & 0.433 & $0.814^{* *}$ & -0.117 \\
\hline & Imports & $1.621^{* * *}$ & $1.036^{* * *}$ & $1.060^{* * *}$ & 1.145 \\
\hline \multirow{4}{*}{ N-S } & Exports & 0.665 & 0.367 & 0.127 & -0.028 \\
\hline & Imports & 0.754 & $0.821^{* * *}$ & $0.654^{\star \star \star}$ & 0.463 \\
\hline & Exports & $-2.616^{* * *}$ & 0.154 & $-3.024^{* * *}$ & $-2.527^{\star * *}$ \\
\hline & Imports & $-0.671^{\star *}$ & -0.272 & -0.230 & $-0.623^{*}$ \\
\hline \multirow{4}{*}{ S-E } & Exports & $-0.554^{* * *}$ & 0.684 & 0.904 & 0.669 \\
\hline & Imports & -0.473 & -1.130 & 0.682 & -0.971 \\
\hline & Exports & $0.592^{* *}$ & $1.762^{*}$ & 0.286 & -0.431 \\
\hline & Imports & 1.202 & -0.228 & $1.336^{*}$ & 0.850 \\
\hline
\end{tabular}
sectoral skill-intensity, though endowments are particularly important for high skill-intensity sectors. On average, human capital endowments increase trade for the North and East but decrease trade for the South. This is in line with the empirical observation that the CEECs are better endowed with human capital than EUSouth and as a consequence have the potential to gain competitiveness in high skill-intensive sectors (or more skill-intensive products within low skill-intensive sectors). In addition, the most sizeable (negative) 
coefficients occur in Southern exports to the North. This situation translates a different type of relationship between the centre and each of the peripheries: Eastern human capital endowments increase imports from the North, but Southern human capital endowments actually decrease Southern exports to the North. This happens in sectors that represent over 2/3 of the exports of Greece, Portugal and Spain and it is evidence pointing to a South-North trade based on the absence of human capital in the South, with the South supplying the North with products at the bottom of the quality ladder, which apparently is in the North's interest, as these are also low-priced goods, thus serving the interests of both consumers and producers in the North. An increase in human capital in the East may increase imports from the North also through both supply and demand links: if the East has more human capital, both firms and consumers will be more demanding, and it will import higher quality, more highly priced inputs and final products from the North.

While endowments per se perform poorly, their interaction with income levels has a significantly positive effect on trade (Table 4). For similar endowments wealth makes a difference, or put differently, for similar levels of income endowments are important. Thus income and endowments are relevant when we talk about countries that are similar in one of the dimensions. This is an

\begin{tabular}{|c|c|c|c|c|c|c|}
\hline \multicolumn{7}{|c|}{ Table 4: Income effects (endowment-weighted) } \\
\hline & & & $\begin{array}{c}\text { High scale } \\
\text { economies and } \\
\text { high skill-intensity }\end{array}$ & $\begin{array}{c}\text { High scale } \\
\text { economies and } \\
\text { low skill-intensity }\end{array}$ & $\begin{array}{c}\text { Low scale } \\
\text { economies and } \\
\text { high skill-intensity }\end{array}$ & $\begin{array}{c}\text { Low scale } \\
\text { economies and } \\
\text { low skill-intensity }\end{array}$ \\
\hline \multirow{4}{*}{$\mathrm{N}-\mathrm{E}$} & \multirow{2}{*}{$\mathrm{N}$} & Exports & $2.411^{\star * *}$ & $2.502^{\star \star *}$ & $2.670^{\star * \star}$ & $2.016^{\star \star \star}$ \\
\hline & & Imports & $1.492^{\star \star \star}$ & $1.701^{\star \star \star}$ & $2.386^{\star * \star}$ & $1.500^{*}$ \\
\hline & \multirow{2}{*}{$\mathrm{E}$} & Exports & $1.694^{\star * \star}$ & $1.263^{* * *}$ & $0.925^{\star \star \star}$ & 0.678 \\
\hline & & Imports & $0.889^{\star \star \star}$ & $0.953^{\star \star *}$ & $0.501^{\star \star *}$ & 0.509 \\
\hline \multirow{4}{*}{ N-S } & \multirow{2}{*}{$\mathrm{N}$} & Exports & 0.504 & $1.805^{\star * *}$ & $3.245^{\star \star \star}$ & $1.316^{\star \star}$ \\
\hline & & Imports & 0.682 & $0.456^{*}$ & 0.620 & 1.462 \\
\hline & & Exports & 0.935 & $1.028^{* * *}$ & $1.478^{*}$ & -0.300 \\
\hline & & Imports & $1.684^{\star \star}$ & $-1.019^{\star \star}$ & -0.983 & 0.792 \\
\hline \multirow{4}{*}{ S-E } & \multirow{2}{*}{$S$} & Exports & $3.576^{\star \star \star *}$ & $3.321^{\star \star \star}$ & $4.107^{\star \star \star}$ & $3.156^{* *}$ \\
\hline & & Imports & 1.368 & $3.976^{\star * *}$ & $1.933^{\star * *}$ & 1.318 \\
\hline & \multirow{2}{*}{$\mathrm{E}$} & Exports & $1.722^{* *}$ & $1.147^{\text {***}}$ & $1.643^{\text {*** }}$ & 0.885 \\
\hline & & Imports & $1.249^{* \star *}$ & 0.488 & $1.094^{\star * *}$ & $0.890^{* *}$ \\
\hline
\end{tabular}
important result, as it shows that low-income countries may have difficulty in turning potential comparative advantages into effective comparative advantages. The issue is certainly topical in transition economies undergoing rapid structural change. Moreover, in centre-periphery trade income effects are amplified by endowments, but the endowment weighing actually reduces the income effects in periphery-periphery trade. Thus, when compared to Table 2, weighted income effects tend to be higher for the most well endowed partner (North in North-East trade or East in South-East trade). For North-South trade the endowment weighting actually reduces the income effects, showing that this trade is more determined by income than by endowments and reinforcing the conclusions on the negative effect of human capital endowments on Southern trade. The weighted income effects are least significant in low scale economies, low skill-intensity sectors, in accordance with the low skill content and price of these goods. The effects are consistently significant across sectors for Northern and Southern exports to the East. When different human capital endowments are accounted for, an increase in income increases exports to the East by over twice as much in the case of North and over three times as much in the case of South. 
The interaction of human capital with distance, which proxies for knowledge spillovers, has an average negative effect on trade (Table 5). As would be expected proximity is important for sharing knowledge and the capacity to do it tends to decrease with distance. Interestingly, while the East seems to benefit from knowledge spillovers from the North, there are no

\begin{tabular}{|c|c|c|c|c|c|c|}
\hline \multicolumn{7}{|c|}{ Table 5: Spillover effects } \\
\hline & & & $\begin{array}{c}\text { High scale } \\
\text { economies and } \\
\text { high skill-intensity }\end{array}$ & $\begin{array}{c}\text { High scale } \\
\text { economies and } \\
\text { low skill-intensity }\end{array}$ & $\begin{array}{c}\text { Low scale } \\
\text { economies and } \\
\text { high skill-intensity }\end{array}$ & $\begin{array}{l}\text { Low scale } \\
\text { economies and } \\
\text { low skill-intensity }\end{array}$ \\
\hline \multirow{4}{*}{$N-E$} & $\mathrm{~N}$ & Exports & -1.502 & $-1.601^{*}$ & $-1.976^{\star \star \star}$ & $-2.136^{\star \star \star}$ \\
\hline & & Imports & -0.631 & -2.360 & $-1.045^{\star * *}$ & -0.412 \\
\hline & $\mathrm{F}$ & Exports & -1.349 & $-0.049^{\star}$ & -0.018 & $-0.843^{*}$ \\
\hline & & Imports & -0.268 & 0.432 & -0.056 & 0.081 \\
\hline \multirow{4}{*}{ N-S } & $\Delta$ & Exports & -1.799 & $-1.743^{*}$ & $-2.833^{\star \star \star}$ & -1.266 \\
\hline & 10 & Imports & -0.980 & -3.665 & 1.054 & $-0.518^{*}$ \\
\hline & a & Exports & $-1.164^{\star}$ & $0.499^{*}$ & $-3.603^{* * *}$ & -1.494 \\
\hline & & Imports & -0.116 & 0.786 & 1.321 & -1.324 \\
\hline \multirow{4}{*}{ S-E } & a & Exports & $-3.195^{\star * *}$ & -1.519 & $-2.733^{\star * \star}$ & -1.606 \\
\hline & | & Imports & $-1.638^{* * *}$ & $-5.153^{\star * \star}$ & -0.859 & -1.555 \\
\hline & $\mathrm{F}$ & Exports & $-0.631^{* *}$ & 0.992 & -0.626 & -0.395 \\
\hline & & Imports & 0.912 & 0.667 & 0.770 & 0.882 \\
\hline
\end{tabular}
significant spillover effects from trade with the South. Again this is in line with the argument that the East is well endowed in human capital and thus would be able to absorb the technological content of traded goods. There seems to be technology embodied in imports from the North, but not in imports from the South. This is because the South is poorly endowed with human capital. However, the spillovers are significant in Southern exports to both North and East, in all sectors except low scale economies, low skill-intensity. This can be better explained as the effect of distance after controlling for endowments: distance decreases Southern exports in both Northern and Eastern markets and can be seen as a major disadvantage for the South.

The results also provide a test of Linder's hypothesis according to which countries with similar demand structures trade more when trade is intra-industry and trade less when trade is interindustry. The answer is provided by the economic distance variable, defined as the absolute

\begin{tabular}{|c|c|c|c|c|c|}
\hline \multicolumn{6}{|c|}{ Table 6: Economic distance effects } \\
\hline & & $\begin{array}{c}\text { High scale } \\
\text { economies and } \\
\text { high skill-intensity }\end{array}$ & $\begin{array}{c}\text { High scale } \\
\text { economies and } \\
\text { low skill-intensity }\end{array}$ & $\begin{array}{c}\text { Low scale } \\
\text { economies and } \\
\text { high skill-intensity }\end{array}$ & $\begin{array}{l}\text { Low scale } \\
\text { economies and } \\
\text { low skill-intensity }\end{array}$ \\
\hline \multirow{2}{*}{$N-E$} & Exports & $1.711^{\star *}$ & $1.688^{* * *}$ & $1.335^{\star \star *}$ & 0.756 \\
\hline & Imports & 0.643 & $0.890^{* *}$ & $1.751^{* * *}$ & 0.633 \\
\hline \multirow{2}{*}{ N-S } & Exports & $0.384^{\star * *}$ & $0.363^{\star * *}$ & $0.585^{\star * *}$ & $0.474^{* * *}$ \\
\hline & Imports & $0.488^{* * *}$ & $0.183^{\star * *}$ & 0.098 & 0.309 \\
\hline \multirow{2}{*}{ S-E } & Exports & -0.831 & 0.384 & -0.261 & -0.352 \\
\hline & Imports & $-2.021^{\star \star \star}$ & $-1.249^{\star \star *}$ & $-0.804^{\star * *}$ & -1.120 \\
\hline
\end{tabular}
difference in the partners' GDPs per capita. Hence this variable measures income differences and these proxy for differences in demand structures. In Table 6, we can clearly distinguish the impact of economic distance on trade between EU-North and both EU-South and the CEECs, on one hand, and trade between EU-South and the CEECs, on the other hand. The impact on centre-periphery trade is positive and mostly significant, except for low scale economies, low skill-intensity sectors, meaning that differences in income actually increase North-South and North-East trade. This is in accordance with a centre-periphery pattern as described in the new economic geography theory. Assuming that wages form the larger part of income, lower incomes represent lower wages and thus lower production costs, which act as an incentive for firms to locate 
in peripheries. On the contrary, this logic does not totally apply to trade between peripheries, as income differences are negatively related to trade, though only significantly for EU-South's imports from the East. Income differences are not significant for Southern exports to the East. However, comparing Table 6 with Table 2, we can see that the income of the exporter is important, except in high scale economies, high skillintensity sectors. Thus wealthier Southern countries would export more, though not necessarily to wealthier Eastern countries. Again a quality argument may be provided: if exports are low quality, they will be demanded by the lower income quartiles and thus that demand is less affected by increases in overall income.

If we think of the effect of economic distance on trade as a test for inter versus intra-industry trade, then North-East and North-South trade would be mainly inter-industry, whereas South-East trade would follow a more mixed pattern, with intra-industry trade predominating on the import side. Rice et al. (2002) present a recent study of the impact of similarities in production and demand on intra-industry trade. They conclude that proximity increases intra-industry trade because neighbouring countries produce and demand a similar mix of products. However, the concept of "proximity" should be seen more in an economic than physical way. Our results provide a good justification. Though North is physically closer to South and East, South and East are economically closer to each other. As a consequence, intra-industry trade is stronger between the peripheries than in centre-periphery trade.

Not only the human capital endowment of each country group is of interest, but also the endowment differences, proxied by the absolute difference in human capital endowments of the partner countries (Table 7). The significance of differences in endowments can be seen as a

\begin{tabular}{|c|c|c|c|c|c|}
\hline \multicolumn{2}{|c|}{ Table 7: Differences in endowments effects } \\
\hline \multicolumn{2}{|c|}{} & $\begin{array}{c}\text { High scale } \\
\text { economies and } \\
\text { high skill-intensity }\end{array}$ & $\begin{array}{c}\text { High scale } \\
\text { economies and } \\
\text { low skill-intensity }\end{array}$ & $\begin{array}{c}\text { Low scale } \\
\text { economies and } \\
\text { high skill-intensity }\end{array}$ & $\begin{array}{c}\text { Low scale } \\
\text { economies and } \\
\text { low skill-intensity }\end{array}$ \\
\hline \multirow{2}{*}{ N-EE } & Exports & -0.022 & $0.067^{*}$ & -0.034 & -0.034 \\
\cline { 2 - 6 } & Imports & -0.092 & $-0.138^{* * *}$ & $0.100^{*}$ & -0.057 \\
\hline \multirow{2}{*}{ N-S } & Exports & 0.019 & 0.015 & -0.003 & -0.004 \\
\cline { 2 - 6 } & Imports & 0.070 & -0.004 & $0.112^{*}$ & 0.115 \\
\hline \multirow{2}{*}{ S-E } & Exports & 0.161 & -0.117 & 0.133 & $0.287^{*}$ \\
\cline { 2 - 6 } & Imports & 0.363 & 0.074 & 0.177 & 0.258 \\
\hline \multicolumn{7}{|c|}{ Note: ${ }^{*},{ }^{* *}$ and ${ }^{* *}$ represent significance at respectively 10,5 and 1\%. } \\
\hline
\end{tabular}
test, even if weak, of the HOS model, especially when the information on factor endowments is crossed with information on factor intensity. In our results, endowment differences are on the whole not significant nor do they show any consistent pattern. This is probably due to the differentiated nature of the sectors considered. 
The differences in endowments per se do not influence trade, but their interactions either with economic (Table 8) or physical distance (Table 9) do. The weighting introduces two major changes in the economic distance effects. First, the negative sign almost disappears

\begin{tabular}{|c|c|c|c|c|c|}
\hline & & $\begin{array}{c}\text { High scale } \\
\text { economies and } \\
\text { high skill-intensity }\end{array}$ & $\begin{array}{c}\text { High scale } \\
\text { economies and } \\
\text { low skill-intensity }\end{array}$ & $\begin{array}{c}\text { Low scale } \\
\text { economies and } \\
\text { high skill-intensity }\end{array}$ & $\begin{array}{l}\text { Low scale } \\
\text { economies and } \\
\text { low skill-intensity }\end{array}$ \\
\hline \multirow{2}{*}{$N-E$} & Exports & $1.784^{\star \star \star}$ & $2.016^{\star * \star}$ & $2.006^{\star * *}$ & $1.741^{* * *}$ \\
\hline & Imports & $1.212^{* * *}$ & $1.542^{* * *}$ & $1.320^{* * *}$ & $1.229^{* * *}$ \\
\hline \multirow{2}{*}{ N-S } & Exports & $0.394^{* * *}$ & $0.428^{* * *}$ & $0.822^{\star \star \star}$ & $0.593^{\star * *}$ \\
\hline & Imports & $0.495^{\star \star \star}$ & $0.173^{\star \star \star}$ & 0.093 & 0.376 \\
\hline \multirow{2}{*}{ S-E } & Exports & $-0.048^{* *}$ & $0.792^{*}$ & 0.419 & 1.089 \\
\hline & Imports & -0.048 & $2.151^{\star * *}$ & 0.448 & $0.144^{\star *}$ \\
\hline
\end{tabular}

from South-East trade, and the effect becomes significantly positive for high scale economies, low skillintensity sectors. Second, the effect becomes significant for North-East trade in low scale economies, low skill-intensity sectors. This is an important finding, as it helps explaining the apparent contradiction between the celebrated abundance of human capital in the CEECs and their specialisation in low skill-intensity sectors during the 1990s. This specialisation was induced by their low income level, not by their endowments and thus, as incomes start rising, the importance of endowments will increase.

As the differences in endowments are not significant, their interaction with distance follows essentially the behaviour of the latter in terms of significance of the effects. The role of endowment differences is mostly to correct the magnitude of the distance effect. This

\begin{tabular}{|c|c|c|c|c|c|}
\hline \multicolumn{6}{|c|}{ Table 9: Distance effects (differences-in-endowments-weighted) } \\
\hline & & $\begin{array}{c}\text { High scale } \\
\text { economies and } \\
\text { high skill-intensity }\end{array}$ & $\begin{array}{c}\text { High scale } \\
\text { economies and } \\
\text { low skill-intensity }\end{array}$ & $\begin{array}{c}\text { Low scale } \\
\text { economies and } \\
\text { high skill-intensity }\end{array}$ & $\begin{array}{c}\text { Low scale } \\
\text { economies and } \\
\text { low skill-intensity }\end{array}$ \\
\hline \multirow{2}{*}{$\mathrm{N}-\mathrm{E}$} & Exports & $-1.794^{\star * *}$ & $-1.973^{\star * *}$ & $-2.091^{\star \star *}$ & $-1.815^{\star \star \star}$ \\
\hline & Imports & $-1.350^{* * *}$ & $-1.754^{\star * *}$ & $-1.197^{* * *}$ & $-1.330^{* * *}$ \\
\hline \multirow{2}{*}{ N-S } & Exports & $-0.395^{\star \star *}$ & $-0.389^{* \star *}$ & $-0.805^{\star * *}$ & $-0.646^{* * *}$ \\
\hline & Imports & -0.405 & $-0.191^{\star \star *}$ & -0.034 & -0.297 \\
\hline \multirow{2}{*}{ S-E } & Exports & $-0.197^{\star *}$ & $-1.051^{* *}$ & $-0.711^{*}$ & -0.967 \\
\hline & Imports & 0.088 & $-2.285^{\star * *}$ & $-0.737^{\star * \star}$ & $-0.227^{\star \star *}$ \\
\hline \multicolumn{6}{|c|}{ Note: * ${ }^{* *}$ and ${ }^{* * *}$ represent significance at respectively 10,5 and $1 \%$. } \\
\hline
\end{tabular}
correction is generally downwards (cf. Table 10) as differences in endowments provide a motive for trade in spite of the distance by compensating higher transport costs with lower production costs. When we control for endowments, distance becomes less important as the former provide another motive for trade. Thus if the advantage in endowments is strong enough it may compensate for a disadvantage in market access.

One of the features of our econometric model is the distinction between spatial and non-spatial trade barriers.

Distance and borders make up spatial barriers whereas the Europe Agreements and EURO dummies constitute non-spatial

\begin{tabular}{|c|c|c|c|c|c|}
\hline \multicolumn{6}{|c|}{ Table 10: Distance effects } \\
\hline & & $\begin{array}{c}\text { High scale } \\
\text { economies and } \\
\text { high skill-intensity }\end{array}$ & $\begin{array}{c}\text { High scale } \\
\text { economies and } \\
\text { low skill-intensity }\end{array}$ & $\begin{array}{c}\text { Low scale } \\
\text { economies and } \\
\text { high skill-intensity }\end{array}$ & $\begin{array}{c}\text { Low scale } \\
\text { economies and } \\
\text { low skill-intensity }\end{array}$ \\
\hline \multirow{2}{*}{$N-E$} & Exports & $-1.708^{* * *}$ & $-2.046^{\star * \star}$ & $-2.316^{\star \star \star}$ & $-2.295^{\star \star \star}$ \\
\hline & Imports & $-1.594^{* *}$ & $-2.052^{* \star *}$ & $-0.903^{* *}$ & $-1.511^{* * *}$ \\
\hline \multirow{2}{*}{ N-S } & Exports & $-1.145^{\star * *}$ & -0.133 & -0.305 & $-2.553^{\star * *}$ \\
\hline & Imports & -0.458 & $-0.665^{\star \star *}$ & $-1.615^{\star \star \star}$ & -1.339 \\
\hline \multirow{2}{*}{ S-E } & Exports & $-2.429^{* * *}$ & $-1.591^{* *}$ & $-2.368^{* * *}$ & -1.147 \\
\hline & Imports & -2.035 & $-3.507^{\star \star \star}$ & $-2.163^{\star * \star}$ & -2.003 \\
\hline
\end{tabular}


trade barriers, or their degree of removal through economic integration. The distance variable is on the whole significantly negative: trade tends to decrease with distance as distance increases transport costs. The distance effect tends to be higher in South-East trade as these countries are peripheries located far apart and with poor transport infrastructures. An increase in distance decreases trade between the two peripheries by up to 3.5 times as much. Even though the distance effects are very negative for the peripheries, Table 9 shows that they are substantially reduced when we control for differences in endowments. If we interpret this as the consequence of poor quality infrastructures with respect to the North, there is still a role for policies of infrastructure improvement that will decrease the market access gap between the EU's centre and its peripheries. In addition, an increase in distance decreases Northern exports of products from low scale economies, low skill-intensity sectors by more than twice as much. Data on sectoral transport costs would be necessary to evaluate the sectoral impact of distance more precisely.

The other component of spatial trade barriers is the existence (or not) of a common border. There is a large literature on border effects, according to which countries that share a common border trade more. In our results we can identify some sectoral significance, especially in

\begin{tabular}{|c|c|c|c|c|c|}
\hline \multicolumn{6}{|c|}{ Table 11: Border effects } \\
\hline \multicolumn{2}{|c|}{} & $\begin{array}{c}\text { High scale } \\
\text { economies and } \\
\text { high skill-intensity }\end{array}$ & $\begin{array}{c}\text { High scale } \\
\text { economies and } \\
\text { low skill-intensity }\end{array}$ & $\begin{array}{c}\text { Low scale } \\
\text { economies and } \\
\text { high skill-intensity }\end{array}$ & $\begin{array}{c}\text { Low scale } \\
\text { economies and } \\
\text { low skill-intensity }\end{array}$ \\
\hline \multirow{2}{*}{ N-E } & Exports & $0.040^{*}$ & 0.169 & -0.426 & -0.041 \\
\cline { 2 - 7 } & Imports & 0.810 & 0.088 & $1.524^{* * *}$ & 0.703 \\
\hline \multirow{2}{*}{ N-S } & Exports & 0.154 & 0.048 & 0.417 & -0.437 \\
\cline { 2 - 6 } & Imports & 0.431 & $0.315^{*}$ & $0.818^{* * *}$ & $0.261^{*}$ \\
\hline \multirow{2}{*}{ S-E } & Exports & 1.496 & 1.525 & $1.935^{\star}$ & 2.300 \\
\cline { 2 - 7 } & Imports & 1.157 & -0.228 & 1.769 & $1.382^{*}$ \\
\hline \multicolumn{7}{|c|}{ Note: ${ }^{*},{ }^{* *}$ and ${ }^{* *}$ represent significance at respectively 10,5 and $1 \%}$. \\
\hline
\end{tabular}
Southern exports to the North. An interesting argument is put forward by Davis (2000) according to which product differentiation tends to reduce the magnitude of the border effect, these being strongest within homogeneous goods categories. As we deal only with manufacturing industry, we can expect products to be differentiated and thus border effects to be insignificant. More research would be necessary on this issue.

The removal of non-spatial trade barriers under economic integration is proxied by the Europe Agreements and the adoption of a single currency. The Europe Agreement effect (Table 12) applies only to the

\begin{tabular}{|c|c|c|c|c|c|}
\hline \multicolumn{2}{|c|}{ Table 12: EA effects } \\
\hline \multirow{2}{*}{} & $\begin{array}{c}\text { High scale } \\
\text { economies and } \\
\text { high skill-intensity }\end{array}$ & $\begin{array}{c}\text { High scale } \\
\text { economies and } \\
\text { low skill-intensity }\end{array}$ & $\begin{array}{c}\text { Low scale } \\
\text { economies and } \\
\text { high skill-intensity }\end{array}$ & $\begin{array}{c}\text { Low scale } \\
\text { economies and } \\
\text { low skill-intensity }\end{array}$ \\
\hline \multirow{2}{*}{ N-E } & Exports & $0.684^{* * *}$ & $0.828^{* * *}$ & $0.621^{* * *}$ & $0.585^{* * *}$ \\
\cline { 2 - 6 } & Imports & $0.572^{*}$ & 0.298 & $0.426^{* * *}$ & $0.544^{* * *}$ \\
\hline \multirow{2}{*}{ S-E } & Exports & $1.255^{* * *}$ & $1.029^{* * *}$ & $1.207^{* * *}$ & 0.699 \\
\cline { 2 - 6 } & Imports & 0.280 & -0.028 & $0.694^{* * *}$ & $0.745^{* *}$ \\
\hline \multicolumn{6}{|c|}{ Note: ${ }^{*}{ }^{* *}$ and ${ }^{* * *}$ represent significance at respectively 10,5 and 1\%. } \\
\hline
\end{tabular}
North-East and South-East pairs and the EURO effect (Table 13) applies only to the North-South pair. On the whole, the Europe Agreements have increased East-West trade and the effects are generally higher in the South-East than in the North-East pair. In both cases it seems that the Europe Agreements have been especially beneficial for trade in high scale economies sectors, though they have not affected Eastern exports to the South in high scale economies sectors. 
Finally, being a Euro zone country does not have an effect on trade among the countries analysed, though again the impact on high-skill sectors tends to be higher. This result is in

\begin{tabular}{|c|c|c|c|c|c|}
\hline \multicolumn{6}{|c|}{ Table 13: EURO effects } \\
\hline & & $\begin{array}{c}\text { High scale } \\
\text { economies and } \\
\text { high skill-intensity }\end{array}$ & $\begin{array}{c}\text { High scale } \\
\text { economies and } \\
\text { low skill-intensity }\end{array}$ & $\begin{array}{c}\text { Low scale } \\
\text { economies and } \\
\text { high skill-intensity }\end{array}$ & $\begin{array}{c}\text { Low scale } \\
\text { economies and } \\
\text { low skill-intensity }\end{array}$ \\
\hline \multirow{2}{*}{ N-S } & Exports & 0.138 & 0.166 & 0.078 & 0.122 \\
\hline & Imports & 0.267 & -0.037 & 0.184 & 0.056 \\
\hline \multicolumn{6}{|c|}{ Note: ${ }^{*},{ }^{* *}$ and ${ }^{* * *}$ represent significance at respectively 10,5 and $1 \%$. } \\
\hline
\end{tabular}
contrast to that of Rose (2000), who found a very large, significant and robust trade effect of currency unions. However, Persson (2001) argued that Rose's result is due to systematic selection into common currencies of country pairs with peculiar characteristics and suggests an alternative methodology that substantially increases uncertainty around the impact of currency unions on trade. Melitz (2001) adds to the argument by considering the effects of forming a currency union on third countries. The idea is that the Euro brings a benefit not just for the Eurozone countries but for those like the UK, who opted out, as in their trade with the Eurozone countries they now deal with just one currency. In our case the magnitude of the standard errors renders the Euro effect on the whole not significant in trade between EU-North and EU-South. This should not be made a case against the Euro. It simply means that Greece, Portugal and Spain have not significantly exported nor imported more from EU-North countries that have adopted the Euro relatively to those who have not. The externality argument can help in explaining this: if a country like the UK has also benefited from the single currency even though it does not participate, then there would be no discernible advantage for trade of Euro and non-Euro EU members. This happens not because the Euro is not beneficial, but because it benefits all countries, even those not participating.

\section{Conclusions}

In this paper we have estimated a sectoral gravity model of trade within a heterogeneous regional trade bloc, the enlarged EU, comprised of a high-income group (North), a medium-income group (South) and a lowincome group (East). We use the estimated coefficients to draw conclusions on the determinants of trade patterns between these three groups in sectors with different degrees of scale economies and skillintensities. As expected, the results reveal important differences across sectors and country groups and offer relevant policy recommendations.

In fact, even though Spain is simultaneously the largest and richest country in the Southern group, its size and income have not significantly enhanced its trade with the East during the 1990s when compared to Portugal and Greece. This can be due to Spain's lower openness to trade in general that carries over to trade with the East. However, size would give Spain a privileged position in high economies of scale sectors and income would give it an advantage in high skill-intensity sectors. In an enlarged EU, these two characteristics have the potential to make Spain a stronger player in the markets for sectors with higher scale economies and higher skill-intensity than would be possible for Portugal and Greece. 
We also find that for the centre (North) size is a more important determinant of trade than income, whereas exactly the opposite is true for the Southern and Eastern peripheries, supporting the argument on the relevance of catching-up in boosting trade. We can think of size as determining trade volume and income as determining unit values, which are a proxy for quality. Along these lines, our finding means that an increase in the income of Southern countries would substantially increase the quality of the products they trade with the rest of the EU. Conversely, for the North, the size effect would mostly increase the volume of trade as the North is already producing higher quality goods. Hence the peripheries income catching-up would have an important impact on product quality catching-up. Another area of impact of income catching-up would be on the enlarged EU internal trade patterns. We find that economic distance increases centre-periphery trade, but decreases periphery-periphery trade. Thus more similarity in incomes across members of the EU has an important consequence: it would tend to decrease the pull of the hub by decreasing centre-periphery and increasing periphery-periphery trade. If we think of the economic distance effect as a test for inter versus intra-industry trade, income catching-up also implies more intra-industry and less inter-industry trade within the EU, which reduces the adjustment costs of enlargement.

Along with size and income, human capital endowments are an important determinant of trade. They reveal a different type of relationship between the centre and each of the peripheries: human capital endowments increase Eastern trade but decrease Southern trade. This finding is in line with the empirical observation that the East is better endowed with human capital than the South and as a consequence has the potential to gain competitiveness in high skill-intensity sectors, or more skill-intensive products within low skill-intensity sectors. Generally, North-South trade is more determined by incomes than by endowments and it is likely to remain so. A different picture is detected in North-East trade. The East specialised in low skill-intensity sectors during the 1990s, but we find that such specialisation was induced by their low income level, not by their endowments. Thus, as incomes start rising, it is likely that the importance of endowments will increase.

Finally, the distance effects are very negative for the peripheries. If we interpret this as the consequence of poor quality infrastructures with respect to the North, there is still a role for policies of infrastructure improvement that will decrease the market access gap between the EU's centre and its peripheries. When we control for differences in endowments, distance becomes less important as the former provide another motive for trade. Thus if the advantage in endowments is strong enough it may compensate for a disadvantage in market access. A good example would be the South's trade in low scale/low skill goods.

The effects on specific sectors differ from what might be suggested by aggregate trade flows. The home market effect tends to be higher in sectors with higher economies of scale. Income and human capital are especially important in sectors with high skill-intensity, though generally not relevant in low scale economies, low skill-intensity sectors. This result is robust to their interaction with distance. The Europe Agreements have been especially beneficial for trade in high scale economies sectors, whereas being a Euro zone country tends to have a higher impact on high-skill sectors. 
Our results come as a support of recent developments in both trade theory and the EU's Agenda 2000. From the theory point of view, we provide empirical justification for the use of hybrid theories in explaining trade patterns. Our specifications bear such hybrid character between the more traditional trade theory based on endowments and the new economic geography based on economies of scale and transport costs.

Economies of scale together with transport costs prove to be an important determinant of trade patterns and, even if non-spatial trade barriers fade away with integration, spatial trade barriers will always have a role to play. In the case of the CEECs, it seems that the human capital endowment does not prevail over market access. On the contrary, trade between EU-North and EU-South seems to be equally related to endowments and market access.

From the policy standpoint, the EU's Agenda 2000 has been a first step in the right direction by emphasising different roles for the EU's Regional Policy. The latter should in fact be a mix of policies, focussing on both income and education/skills, together with infrastructure development. This last aspect has successfully benefited Southern Europe and the same would be expected in Eastern Europe. The same recommendation can be carried over to developing countries that suffer from poor market access and low human capital endowments. When these integrate with more developed countries, it is important to adopt a balanced mix of policies, fostering both income and education/skill levels, together with infrastructure improvement. The excessive focus on one of the policies without the right balance may do more harm than good. 


\section{Appendix A \\ Data Sources}

Data is taken for the transition period, this is, $1990-99$, for the following aggregates of SITC Rev. 2 sectors: chemicals $(5)$, leather products $(61,85)$, machinery $(71-77)$, metals $(67-69)$, minerals $(66)$, textiles and clothing $(65,84)$, transport equipment $(78,79)$, and wood products $(63,82)$. Trade data (value of exports and imports) is provided by the OECD International Trade Statistics CD-ROM in thousands USD.

Trade liberalisation with the East is accounted for by means of a dummy variable. For each Eastern country it is defined as taking a value of one after the year of signature of the Europe Agreements. The data for all regional trade associations was taken from the WTO website (www.wto.org).

Data for distances and borders was taken from the CEPII website (www.cepii.fr). Distance data is measured in km between the partner countries' economic centres. These correspond to the capital city except for Germany (Hamburg is the city used). Countries are considered to share a common border when they share a land border or a small body of water border.

Data for population (given in thousands) and for GDP (given in billions USD at 1995 prices and exchange rates) was taken from the web version of IMF's International Financial Statistics at www.imf.org.

The schooling variable is given by the number of people with tertiary education studies. This number was obtained from the Barro-Lee dataset for 1990 and then added of the yearly number of enrolments. The enrolment data was taken from the web versions of OECD Education Statistics and UNESCO Statistics of Educational Attainment and Literacy at www.oecd.org and www.unesco.org. 


\section{Appendix B}

\section{Prais-Winsten Regression with Panel-specific AR(1) Correlated Panels Corrected Standard Errors ${ }^{8}$}

\begin{tabular}{|c|c|c|c|c|c|c|c|c|c|c|c|c|c|c|c|c|c|c|c|c|c|c|c|c|}
\hline \multirow{3}{*}{ Chemicals } & \multicolumn{8}{|c|}{ North-East } & \multicolumn{8}{|c|}{ North-South } & \multicolumn{8}{|c|}{ South-East } \\
\hline & \multicolumn{4}{|c|}{$\begin{array}{l}\text { Dependent Variable: Export Value } \\
\end{array}$} & \multicolumn{4}{|c|}{ Dependent Variable: Import Value } & \multicolumn{4}{|c|}{$\begin{array}{l}\text { Dependent Variable: Export Value } \\
\end{array}$} & \multicolumn{4}{|c|}{ Dependent Variable: Import Value } & \multicolumn{4}{|c|}{$\begin{array}{l}\text { Dependent Variable: Export Value } \\
\end{array}$} & \multicolumn{4}{|c|}{ Dependent Variable: Import Value } \\
\hline & Model 1 & Model 2 & Model 3 & Model 4 & Model 1 & \begin{tabular}{|l|} 
Model 2 \\
\end{tabular} & \begin{tabular}{|l|} 
Model 3 \\
\end{tabular} & Model 4 & Model 1 & Model 2 & \begin{tabular}{|l|} 
Model 3 \\
\end{tabular} & \begin{tabular}{|l|} 
Model 4 \\
\end{tabular} & Model 1 & Model 2 & \begin{tabular}{|l|} 
Model 3 \\
\end{tabular} & Model 4 & Model 1 & Model 2 & \begin{tabular}{|l|} 
Model 3 \\
\end{tabular} & Model 4 & \begin{tabular}{|l|} 
Model 1 \\
\end{tabular} & \begin{tabular}{|l|} 
Model 2 \\
\end{tabular} & Model 3 & Model 4 \\
\hline popi & $\begin{array}{c}1.088^{\star \star \star} \\
(0.050)\end{array}$ & \begin{tabular}{|c|}
$1.094^{\star * *}$ \\
$(0.057)$ \\
\end{tabular} & $\begin{array}{c}1.105^{\star \star *} \\
(0.055)\end{array}$ & $\begin{array}{c}1.082^{* * \star} \\
(0.058) \\
\end{array}$ & $\begin{array}{c}1.290^{* * *} \\
(0.054) \\
\end{array}$ & $\begin{array}{l}1.246^{\star \star \star} \\
(0.070)\end{array}$ & \begin{tabular}{|c|}
$1.249 * * *$ \\
$(0.066)$ \\
\end{tabular} & $\begin{array}{c}1.301^{\star * \star} \\
(0.062)\end{array}$ & $\begin{array}{c}0.998^{\star \star *} \\
(0.061)\end{array}$ & $\begin{array}{c}0.984^{\star \star \star} \\
(0.066) \\
\end{array}$ & $\begin{array}{c}1.178^{\star * *} \\
(0.062) \\
\end{array}$ & $\begin{array}{c}1.116^{\star \star *} \\
(0.045)\end{array}$ & $\begin{array}{c}1.109^{\star \star \star} \\
(0.072)\end{array}$ & $\begin{array}{c}1.061^{\star \star \star} \\
(0.069) \\
\end{array}$ & $\begin{array}{l}0.979^{\star \star \star} \\
(0.050)\end{array}$ & $\begin{array}{c}0.949 * * \star \\
(0.063)\end{array}$ & \begin{tabular}{c|}
$2.524^{\star \star \star}$ \\
$(0.648)$ \\
\end{tabular} & $\begin{array}{c}1.570^{\star \star \star} \\
(0.251)\end{array}$ & \begin{tabular}{|c|}
$2.437 * \star *$ \\
$(0.299)$ \\
\end{tabular} & $\begin{array}{c}1.549^{\star \star \star} \\
(0.326)\end{array}$ & \begin{tabular}{|l|}
$1.619^{\star *}$ \\
$(0.790)$ \\
\end{tabular} & $\begin{array}{c}0.701^{\star * \star} \\
(0.276)\end{array}$ & \begin{tabular}{|c|}
$1.697 * \star *$ \\
$(0.357)$ \\
\end{tabular} & $\begin{array}{l}1.856^{\star \star \star} \\
(0.241)\end{array}$ \\
\hline popj & $\begin{array}{l}1.276^{\star \star \star} \\
(0.134)\end{array}$ & $\begin{array}{c}1.304^{\star \star *} \\
(0.151) \\
\end{array}$ & $\begin{array}{c}0.987 * \star * \\
(0.114)\end{array}$ & $\begin{array}{l}0.985 * * \star \\
(0.126)\end{array}$ & $\begin{array}{c}1.397^{* * k} \\
(0.103)\end{array}$ & $\begin{array}{c}1.276^{\star \star \star} \\
(0.114)\end{array}$ & $\begin{array}{c}0.949^{* * *} \\
(0.071)\end{array}$ & $\begin{array}{c}0.893^{\star * \star} \\
(0.069)\end{array}$ & $\begin{array}{c}0.033 \\
(0.222) \\
\end{array}$ & $\begin{array}{c}0.115 \\
(0.157) \\
\end{array}$ & $\begin{array}{c}0.978^{\star \star \star} \\
(0.093)\end{array}$ & $\begin{array}{c}1.130^{\star \star \star} \\
(0.059) \\
\end{array}$ & $\begin{array}{c}0.412 \\
(0.341)\end{array}$ & $\begin{array}{c}1.053^{\star \star \star} \\
(0.181) \\
\end{array}$ & $\begin{array}{l}1.896^{\star \star \star} \\
(0.089)\end{array}$ & $\begin{array}{c}1.766^{\star \star \star} \\
(0.164) \\
\end{array}$ & $\begin{array}{c}1.077^{\star \star \star} \\
(0.128)\end{array}$ & \begin{tabular}{|c|}
$0.992^{\star * \star}$ \\
$(0.131)$ \\
\end{tabular} & $\begin{array}{c}0.326 \\
(0.245) \\
\end{array}$ & $\begin{array}{c}0.249 \\
(0.338) \\
\end{array}$ & $\begin{array}{c}1.480^{\star \star \star} \\
(0.149) \\
\end{array}$ & $\begin{array}{l}1.360^{\star * \star} \\
(0.128)\end{array}$ & $\begin{array}{c}1.280^{\star * *} \\
(0.135) \\
\end{array}$ & $\begin{array}{c}1.147^{\star \star \star} \\
(0.128) \\
\end{array}$ \\
\hline gdppci & $\begin{array}{c}2.019^{\star \star \star} \\
(0.368)\end{array}$ & & & & $\begin{array}{l}-0.044 \\
(0.517) \\
\end{array}$ & & & & $\begin{array}{c}0.259 \\
(0.240) \\
\end{array}$ & & & & $\begin{array}{c}0.362 \\
(0.384) \\
\end{array}$ & & & & $\begin{array}{c}1.185 \\
(2.228) \\
\end{array}$ & & & & $\begin{array}{c}-1.264 \\
(3.228)\end{array}$ & & & \\
\hline gdppcj & $\begin{array}{l}0.982^{\star \star \star} \\
(0.217)\end{array}$ & & & & $\begin{array}{l}0.954^{\star \star \star} \\
(0.188)\end{array}$ & & & & $\begin{array}{c}3.054^{\star \star \star} \\
(0.887)\end{array}$ & & & & $\begin{array}{c}4.657^{\star \star \star} \\
(1.288)\end{array}$ & & & & $\begin{array}{c}1.094^{\star \star \star} \\
(0.279)\end{array}$ & & & & $\begin{array}{l}0.379^{\star *} \\
(0.183)\end{array}$ & & & \\
\hline gdppci*hkpci & & $\begin{array}{c}1.821^{\star \star \star} \\
(0.206)\end{array}$ & & & & $\begin{array}{c}1.125^{\star \star \star} \\
(0.379)\end{array}$ & & & & $\begin{array}{c}0.031 \\
(0.325)\end{array}$ & & & & $\begin{array}{c}0.133 \\
(0.387)\end{array}$ & & & & $\begin{array}{c}5.199^{\star \star \star} \\
(0.837)\end{array}$ & & & & $\begin{array}{c}2.516^{\star \star \star} \\
(0.656)\end{array}$ & & \\
\hline gdppcj*hkpcj & & $\begin{array}{l}0.968^{\star \star \star} \\
(0.207) \\
\end{array}$ & & & & $\begin{array}{l}0.862^{* \star \star} \\
(0.184) \\
\end{array}$ & & & & $\begin{array}{c}2.958^{\star \star \star} \\
(0.499)\end{array}$ & & & & $\begin{array}{l}1.336^{\star \star \star} \\
(0.523)\end{array}$ & & & & $\begin{array}{l}0.980^{* k *} \\
(0.282)\end{array}$ & & & & $\begin{array}{l}0.329^{*} \\
(0.188)\end{array}$ & & \\
\hline ecdist & & & $\begin{array}{c}1.583^{\star \star \star} \\
(0.378)\end{array}$ & & & & $\begin{array}{c}-0.053 \\
(0.325)\end{array}$ & & & & $\begin{array}{l}0.518^{\star \star \star} \\
(0.124)\end{array}$ & & & & $\begin{array}{l}0.335^{\star \star \star} \\
(0.092)\end{array}$ & & & & $\begin{array}{c}-0.131 \\
(0.524)\end{array}$ & & & & \begin{tabular}{|c}
$-0.986^{\star \star \star}$ \\
$(0.382)$
\end{tabular} & \\
\hline ecdistthkdist & & & & $\begin{array}{c}1.296^{\star \star \star} \\
(0.167)\end{array}$ & & & & $\begin{array}{c}0.786^{\star \star \star} \\
(0.182)\end{array}$ & & & & \begin{tabular}{|c|}
$0.451^{\star \star \star}$ \\
$(0.098)$
\end{tabular} & & & & $\begin{array}{l}0.311^{\star *} \\
(0.129)\end{array}$ & & & & $\begin{array}{c}2.075^{\star \star \star} \\
(0.803)\end{array}$ & & & & $\begin{array}{c}-0.659 \\
(0.591)\end{array}$ \\
\hline hkpci & $\begin{array}{c}0.196 \\
(0.126)\end{array}$ & & & & $\begin{array}{c}0.648^{\star} \\
(0.356)\end{array}$ & & & & $\begin{array}{c}1.276^{\star \star \star} \\
(0.203)\end{array}$ & & & & $\begin{array}{l}1.171^{\star \star \star} \\
(0.307)\end{array}$ & & & & $\begin{array}{c}3.383^{\star \star \star} \\
(0.623)\end{array}$ & & & & $\begin{array}{c}-0.030 \\
(0.739)\end{array}$ & & & \\
\hline hkpcj & $\begin{array}{l}1.275^{\star \star \star} \\
(0.306)\end{array}$ & & & & $\begin{array}{c}1.437^{\star \star \star} \\
(0.438)\end{array}$ & & & & $\begin{array}{c}-0.358^{*} \\
(0.188)\end{array}$ & & & & $\begin{array}{c}-1.293^{\star \star \star} \\
(0.247)\end{array}$ & & & & $\begin{array}{c}2.110^{\star \star \star} \\
(0.692)\end{array}$ & & & & $\begin{array}{c}1.855^{\star \star \star} \\
(0.509)\end{array}$ & & & \\
\hline hkdist & & & $\begin{array}{l}-0.007 \\
(0.036)\end{array}$ & & & & $\begin{array}{c}-0.072 \\
(0.054) \\
\end{array}$ & & & & $\begin{array}{c}0.026 \\
(0.026) \\
\end{array}$ & & & & $\begin{array}{l}0.093^{\star \star} \\
(0.049)\end{array}$ & & & & $\begin{array}{c}0.148 \\
(0.115)\end{array}$ & & & & \begin{tabular}{|c|}
$0.361^{\star \star *}$ \\
$(0.122)$
\end{tabular} & \\
\hline disthkpci & & \begin{tabular}{|c|}
$-1.537^{\star \star \star}$ \\
$(0.222)$
\end{tabular} & & & & \begin{tabular}{|c|}
$-1.093^{\star \star \star}$ \\
$(0.372)$
\end{tabular} & & & & $\begin{array}{c}1.234^{\star \star \star} \\
(0.438)\end{array}$ & & & & \begin{tabular}{|c}
$1.579^{\star \star \star}$ \\
$(0.593)$
\end{tabular} & & & & $\begin{array}{c}-2.253^{\star \star} \\
(1.032)\end{array}$ & & & & \begin{tabular}{|c|}
$-3.209^{\star \star \star}$ \\
$(0.713)$
\end{tabular} & & \\
\hline dist*hkpcj & & $\begin{array}{c}0.447^{*} \\
(0.235) \\
\end{array}$ & & & & $\begin{array}{c}-0.011 \\
(0.325) \\
\end{array}$ & & & & $\begin{array}{c}-3.281^{\star \star \star} \\
(0.575) \\
\end{array}$ & & & & $\begin{array}{c}-2.333^{\star \star \star} \\
(0.607) \\
\end{array}$ & & & & $\begin{array}{c}0.539 \\
(0.674) \\
\end{array}$ & & & & $\begin{array}{l}0.986^{\star \star} \\
(0.513) \\
\end{array}$ & & \\
\hline dist*hkdist & & & & $\begin{array}{c}-1.276^{\star \star \star} \\
(0.182)\end{array}$ & & & & $\begin{array}{c}-0.945^{\star \star \star} \\
(0.176) \\
\end{array}$ & & & & \begin{tabular}{|c|}
$-0.454^{\star \star \star}$ \\
$(0.099)$ \\
\end{tabular} & & & & $\begin{array}{l}-0.197 \\
(0.162) \\
\end{array}$ & & & & $\begin{array}{c}-2.105^{\star \star \star} \\
(0.712) \\
\end{array}$ & & & & $\begin{array}{c}0.648 \\
(0.553)\end{array}$ \\
\hline dist & $\begin{array}{c}-1.030^{\star \star \star} \\
(0.326)\end{array}$ & & $\begin{array}{c}-1.141^{\star \star \star} \\
(0.278)\end{array}$ & & $\begin{array}{c}-1.426^{\star \star \star} \\
(0.363)\end{array}$ & & $\begin{array}{c}-1.398^{\star \star \star} \\
(0.315)\end{array}$ & & \begin{tabular}{|c|}
$-2.072^{\star \star \star}$ \\
$(0.228)$ \\
\end{tabular} & & $\begin{array}{c}-1.224^{\star \star \star} \\
(0.166)\end{array}$ & & $\begin{array}{l}-0.331 \\
(0.282) \\
\end{array}$ & & $\begin{array}{l}-0.050 \\
(0.405) \\
\end{array}$ & & $\begin{array}{c}-1.574^{\star \star \star} \\
(0.467)\end{array}$ & & $\begin{array}{c}-3.587^{\star \star \star} \\
(0.480)\end{array}$ & & $\begin{array}{c}-2.070 * \star \star \\
(0.356) \\
\end{array}$ & & $\begin{array}{c}-1.455^{\star \star \star} \\
(0.156) \\
\end{array}$ & \\
\hline border & $\begin{array}{l}0.929^{*} \\
(0.493)\end{array}$ & $\begin{array}{l}0.821^{* *} \\
(0.354)\end{array}$ & $\begin{array}{l}0.872^{\star *} \\
(0.380)\end{array}$ & $\begin{array}{c}0.637^{* * *} \\
(0.230)\end{array}$ & $\begin{array}{c}0.406 \\
(0.284)\end{array}$ & $\begin{array}{c}0.641^{\star \star \star} \\
(0.243)\end{array}$ & $\begin{array}{c}0.018 \\
(0.464)\end{array}$ & $\begin{array}{c}1.167^{\star \star \star} \\
(0.239)\end{array}$ & $\begin{array}{c}-0.049 \\
(0.100)\end{array}$ & $\begin{array}{l}-0.146 \\
(0.136)\end{array}$ & $\begin{array}{l}-0.073 \\
(0.130)\end{array}$ & $\begin{array}{l}0.187^{*} \\
(0.105)\end{array}$ & $\begin{array}{c}0.622^{\star \star \star} \\
(0.161)\end{array}$ & \begin{tabular}{|c|}
$0.771^{\star \star *}$ \\
$(0.161)$
\end{tabular} & $\begin{array}{l}0.450^{*} \\
(0.253)\end{array}$ & $\begin{array}{l}0.560^{*} \\
(0.300)\end{array}$ & $\begin{array}{c}0.304 \\
(0.694)\end{array}$ & $\begin{array}{c}0.413 \\
(0.704)\end{array}$ & $\begin{array}{c}-0.905 \\
(0.577)\end{array}$ & $\begin{array}{c}0.997 \\
(1.084)\end{array}$ & $\begin{array}{c}0.234 \\
(0.407)\end{array}$ & $\begin{array}{c}0.478 \\
(0.397)\end{array}$ & $\begin{array}{c}1.849^{\star \star \star} \\
(0.274)\end{array}$ & $\begin{array}{c}5.373^{\star \star \star} \\
(1.061)\end{array}$ \\
\hline EA & $\begin{array}{l}0.688^{\star \star \star} \\
(0.200)\end{array}$ & $\begin{array}{l}0.686^{\star \star \star} \\
(0.200)\end{array}$ & $\begin{array}{c}0.788^{\star \star \star} \\
(0.197)\end{array}$ & $\begin{array}{l}0.778^{\star \star \star} \\
(0.207)\end{array}$ & $\begin{array}{c}0.134 \\
(0.164) \\
\end{array}$ & $\begin{array}{c}0.152 \\
(0.163)\end{array}$ & $\begin{array}{l}0.261^{*} \\
(0.150) \\
\end{array}$ & $\begin{array}{l}0.237^{\star} \\
(0.145)\end{array}$ & & & & & & & & & \begin{tabular}{c|}
$0.951^{\star \star \star}$ \\
$(0.210)$ \\
\end{tabular} & \begin{tabular}{|c|}
$0.836^{\star \star \star}$ \\
$(0.194)$ \\
\end{tabular} & $\begin{array}{c}1.733^{\star \star \star} \\
(0.225) \\
\end{array}$ & \begin{tabular}{|c|}
$1.273^{\star \star \star}$ \\
$(0.242)$ \\
\end{tabular} & $\begin{array}{l}0.406^{\star \star} \\
(0.200) \\
\end{array}$ & $\begin{array}{l}0.317^{*} \\
(0.180)\end{array}$ & \begin{tabular}{|l}
$0.482^{\star \star}$ \\
$(0.212)$ \\
\end{tabular} & $\begin{array}{l}0.371^{\star} \\
(0.223)\end{array}$ \\
\hline EURO & & & & & & & & & $\begin{array}{l}-0.025 \\
(0.082) \\
\end{array}$ & $\begin{array}{c}-0.021 \\
(0.079) \\
\end{array}$ & $\begin{array}{c}0.107 \\
(0.113) \\
\end{array}$ & \begin{tabular}{c|}
0.114 \\
$(0.110)$ \\
\end{tabular} & $\begin{array}{c}-0.103 \\
(0.129) \\
\end{array}$ & $\begin{array}{c}0.119 \\
(0.129) \\
\end{array}$ & $\begin{array}{c}0.101 \\
(0.128) \\
\end{array}$ & \begin{tabular}{|c|}
0.103 \\
$(0.133)$ \\
\end{tabular} & & & & & & & & \\
\hline constant & $\begin{array}{c}-39.087^{\star \star \star} \\
(8.313) \\
\end{array}$ & $\begin{array}{c}-36.448^{\star \star \star \star} \\
(4.718) \\
\end{array}$ & $\begin{array}{c}-26.093^{\star \star \star} \\
(6.766) \\
\end{array}$ & $\begin{array}{c}-21.698^{\star \star \star} \\
(2.478) \\
\end{array}$ & \begin{tabular}{|c|}
$-19.5777^{* \star}$ \\
$(9.149)$ \\
\end{tabular} & $\begin{array}{c}-33.669^{* \star \star} \\
(4.058) \\
\end{array}$ & $\begin{array}{c}-10.697^{* \star \star} \\
(5.104) \\
\end{array}$ & $\begin{array}{c}-22.605^{\star \star \star} \\
(1.096) \\
\end{array}$ & $\begin{array}{c}-11.710^{*} \\
(6.518) \\
\end{array}$ & $\begin{array}{c}-9.650^{\star \star \star} \\
(2.720) \\
\end{array}$ & $\begin{array}{c}-12.863^{* \star \star} \\
(3.674) \\
\end{array}$ & $\begin{array}{c}-19.556^{* \star *} \\
(1.382) \\
\end{array}$ & $\begin{array}{c}-53.693^{\star * \star} \\
(7.309)\end{array}$ & $\begin{array}{c}-24.331^{\star \star *} \\
(3.372) \\
\end{array}$ & \begin{tabular}{|c|}
$-32.731^{* \star *}$ \\
$(3.736)$ \\
\end{tabular} & $\begin{array}{c}-28.659^{\star * *} \\
(3.396) \\
\end{array}$ & \begin{tabular}{|c|}
$-37.671^{\star \star \star}$ \\
$(12.990)$ \\
\end{tabular} & $\begin{array}{c}-59.299^{\star \star \star} \\
(6.114) \\
\end{array}$ & \begin{tabular}{|c}
-4.375 \\
$(3.581)$ \\
\end{tabular} & $\begin{array}{c}-20.556^{\star \star \star} \\
(6.441) \\
\end{array}$ & \begin{tabular}{|c|}
$-6.633^{\star * \star}$ \\
$(18.444)$ \\
\end{tabular} & $\begin{array}{c}-27.111^{\star \star \star} \\
(5.585) \\
\end{array}$ & $\begin{array}{c}-13.132^{\star *} \\
(5.442) \\
\end{array}$ & $\begin{array}{c}-34.425^{\star * \star} \\
(4.328)\end{array}$ \\
\hline No obs & 915 & 915 & 915 & 915 & 902 & 902 & 902 & 902 & 320 & 320 & 320 & 320 & 321 & 321 & 321 & 321 & 239 & 239 & 239 & 239 & 226 & \begin{tabular}{|l|}
226 \\
\end{tabular} & 226 & 226 \\
\hline & 0.9811 & \begin{tabular}{|l|}
0.9811 \\
\end{tabular} & 0.9799 & 0.9775 & 0.962 & 0.963 & \begin{tabular}{|l|}
0.967 \\
\end{tabular} & \begin{tabular}{|l|}
0.966 \\
\end{tabular} & 0.998 & 0.998 & 0.996 & \begin{tabular}{|l|l|}
0.998 \\
\end{tabular} & 0.993 & 0.992 & \begin{tabular}{|l|l|}
0.991 \\
\end{tabular} & 0.991 & \begin{tabular}{|c|}
0.9373 \\
\end{tabular} & 0.936 & \begin{tabular}{|l|}
0.9292 \\
\end{tabular} & 0.9367 & \begin{tabular}{l|l}
0.958 \\
\end{tabular} & \begin{tabular}{|l|}
0.955 \\
\end{tabular} & \begin{tabular}{|l|}
0.964 \\
\end{tabular} & 0.973 \\
\hline Wald Chi2 & $2740.17^{\star \star *}$ & $2657.21^{\star \star \star *}$ & $3974.91^{* *}$ & $2401.81^{\star \star \star *}$ & $3980.39^{\circ * \star *}$ & $3184.75^{* \star *}$ & $3105.07^{* * *}$ & $2686.67 \times \star \star x$ & $4846.72^{2 * \star *}$ & $5112.73^{* \star \star}$ & $1322.02^{2 * \star *}$ & $3234.27 \times * \star$ & $8188.41^{1 * * *}$ & $7243.64 * \star x$ & $1681.05^{* \star \star *}$ & $1985.75^{\star \star \star}$ & $1137.35^{* \star *}$ & $757.59^{\star \star \star \star}$ & $931.52^{\star \star \star}$ & $385.02^{* \star \star}$ & $1322.41^{1 * \star *}$ & $3156.34^{* * *}$ & $1680.52^{* \star *}$ & (1159.86 \\
\hline
\end{tabular}

${ }^{8}$ Standard errors are shown in parenthesis. * ${ }^{* *}$ and ${ }^{* \star *}$ represent significance at 10,5 and $1 \%$, respectively. 


\begin{tabular}{|c|c|c|c|c|c|c|c|c|c|c|c|c|c|c|c|c|c|c|c|c|c|c|c|c|}
\hline \multirow{3}{*}{$\begin{array}{l}\text { Leather \& } \\
\text { Footwear }\end{array}$} & \multicolumn{8}{|c|}{ North-East } & \multicolumn{8}{|c|}{ North-South } & \multicolumn{8}{|c|}{ South-East } \\
\hline & \multicolumn{4}{|c|}{ Dependent Variable: Export Value } & \multicolumn{4}{|c|}{ Dependent Variable: Import Value } & \multicolumn{4}{|c|}{ Dependent Variable: Export Value } & \multicolumn{4}{|c|}{\begin{tabular}{|l|} 
Dependent Variable: Import Value \\
\end{tabular}} & \multicolumn{4}{|c|}{ Dependent Variable: Export Value } & \multicolumn{4}{|c|}{\begin{tabular}{|l|} 
Dependent Variable: Import Value \\
\end{tabular}} \\
\hline & Model 1 & Model 2 & Model 3 & Model 4 & \begin{tabular}{l|l} 
Model 1 \\
\end{tabular} & Model 2 & \begin{tabular}{|l|l|} 
Model 3 \\
\end{tabular} & Model 4 & Model 1 & Model 2 & Model 3 & Model 4 & \begin{tabular}{l|l} 
Model 1 \\
\end{tabular} & \begin{tabular}{|l|} 
Model 2 \\
\end{tabular} & Model 3 & Model 4 & \begin{tabular}{l|l} 
Model 1 \\
\end{tabular} & \begin{tabular}{|l|} 
Model 2 \\
\end{tabular} & Model 3 & Model 4 & \begin{tabular}{|l|} 
Model 1 \\
\end{tabular} & Model 2 & \begin{tabular}{|l|l|} 
Model 3 \\
\end{tabular} & Model 4 \\
\hline popi & $\begin{array}{c}1.556^{\star \star \star} \\
(0.073)\end{array}$ & $\begin{array}{c}1.568^{\star \star \star} \\
(0.078)\end{array}$ & $\begin{array}{c}1.582^{\star \star \star} \\
(0.070)\end{array}$ & $\begin{array}{c}1.532^{\star \star \star} \\
(0.079)\end{array}$ & $\begin{array}{c}1.309^{\star \star \star} \\
(0.053)\end{array}$ & $\begin{array}{c}1.292^{\star \star \star} \\
(0.070)\end{array}$ & $\begin{array}{c}1.307^{\star \star \star} \\
(0.060)\end{array}$ & $\begin{array}{c}1.349^{\star \star \star} \\
(0.073)\end{array}$ & $\begin{array}{l}1.213^{\star \star \star} \\
(0.070)\end{array}$ & $\begin{array}{c}1.231^{\star \star \star} \\
(0.069)\end{array}$ & $\begin{array}{c}1.106^{\star \star \star} \\
(0.116)\end{array}$ & $\begin{array}{l}1.458^{\star \star \star} \\
(0.088)\end{array}$ & $\begin{array}{c}1.173^{\star \star \star} \\
(0.081)\end{array}$ & $\begin{array}{c}1.203^{\star \star \star} \\
(0.084)\end{array}$ & $\begin{array}{l}1.209^{\star \star \star} \\
(0.099)\end{array}$ & $\begin{array}{c}1.485^{\star \star \star} \\
(0.169)\end{array}$ & $\begin{array}{c}-0.577 \\
(0.722)\end{array}$ & $\begin{array}{l}0.637^{\star \star} \\
(0.320)\end{array}$ & $\begin{array}{c}1.286^{\star \star \star} \\
(0.314)\end{array}$ & $\begin{array}{l}0.691^{\star \star} \\
(0.355)\end{array}$ & $\begin{array}{c}0.551 \\
(1.229)\end{array}$ & $\begin{array}{c}1.665^{\star \star \star} \\
(0.681)\end{array}$ & $\begin{array}{c}1.883^{\star \star \star} \\
(0.417)\end{array}$ & $\begin{array}{c}1.513^{\star \star \star} \\
(0.516)\end{array}$ \\
\hline popj & $\begin{array}{c}0.776^{\star \star \star} \\
(0.109)\end{array}$ & $\begin{array}{c}0.686^{\star \star \star} \\
(0.095)\end{array}$ & $\begin{array}{l}0.679^{* \star \star} \\
(0.067)\end{array}$ & $\begin{array}{c}0.595^{* \star \star} \\
(0.068)\end{array}$ & $\begin{array}{c}0.932^{\star \star *} \\
(0.199)\end{array}$ & $\begin{array}{c}0.991^{\star \star \star} \\
(0.156)\end{array}$ & $\begin{array}{c}0.980^{* \star \star} \\
(0.115)\end{array}$ & $\begin{array}{l}1.050^{* \star \star} \\
(0.113)\end{array}$ & $\begin{array}{c}-0.944^{* *} \\
(0.431)\end{array}$ & $\begin{array}{c}-1.177^{* \star \star} \\
(0.315)\end{array}$ & $\begin{array}{c}-0.626^{\star \star \star} \\
(0.240)\end{array}$ & $\begin{array}{l}-0.079 \\
(0.215)\end{array}$ & $\begin{array}{l}-0.539 \\
(0.606)\end{array}$ & $\begin{array}{c}0.759^{\star \star \star} \\
(0.208)\end{array}$ & $\begin{array}{c}1.734^{\star \star \star} \\
(0.179)\end{array}$ & \begin{tabular}{|c|}
$2.281^{* * \star}$ \\
$(0.284)$
\end{tabular} & $\begin{array}{c}0.759^{\star \star \star} \\
(0.196)\end{array}$ & $\begin{array}{c}0.855^{\star \star \star} \\
(0.215)\end{array}$ & \begin{tabular}{|c}
$0.624^{\star \star \star}$ \\
$(0.215)$
\end{tabular} & $\begin{array}{l}0.541^{* *} \\
(0.230)\end{array}$ & $\begin{array}{l}0.836^{* \star} \\
(0.365)\end{array}$ & $\begin{array}{l}1.026^{\star \star \star} \\
(0.310)\end{array}$ & $\begin{array}{c}1.137^{* \star \star} \\
(0.253)\end{array}$ & $\begin{array}{l}0.843^{\star \star \star} \\
(0.250)\end{array}$ \\
\hline gdppci & $\begin{array}{c}0.286 \\
(0.467)\end{array}$ & & & & $\begin{array}{c}0.751 \\
(0.739)\end{array}$ & & & & $\begin{array}{c}0.594 \\
(0.380)\end{array}$ & & & & $\begin{array}{c}3.115^{\star \star \star} \\
(0.586)\end{array}$ & & & & $\begin{array}{l}6.667 * \star \\
(3.031)\end{array}$ & & & & $\begin{array}{c}2.255 \\
(4.217)\end{array}$ & & & \\
\hline gdppcj & $\begin{array}{l}0.323^{*} \\
(0.187)\end{array}$ & & & & $\begin{array}{c}0.807^{\star \star \star} \\
(0.200)\end{array}$ & & & & $\begin{array}{c}0.772 \\
(1.604)\end{array}$ & & & & $\begin{array}{l}5.372^{\star \star} \\
(2.296)\end{array}$ & & & & $\begin{array}{l}1.049^{\star \star \star} \\
(0.163)\end{array}$ & & & & $\begin{array}{c}0.976 \\
(0.699)\end{array}$ & & & \\
\hline gdppci*hkpci & & $\begin{array}{l}1.096^{\star \star \star} \\
(0.312)\end{array}$ & & & & $\begin{array}{c}0.332 \\
(0.283)\end{array}$ & & & & $\begin{array}{c}0.539 \\
(0.383)\end{array}$ & & & & $\begin{array}{c}2.623^{\star \star \star} \\
(0.630)\end{array}$ & & & & $\begin{array}{l}1.418^{\star} \\
(0.774) \\
\end{array}$ & & & & $\begin{array}{l}-1.978 \\
(1.709) \\
\end{array}$ & & \\
\hline gdppcj*hkpcj & & $\begin{array}{l}0.327^{*} \\
(0.200)\end{array}$ & & & & $\begin{array}{l}0.785^{\star \star *} \\
(0.209)\end{array}$ & & & & $\begin{array}{l}1.811^{\star \star} \\
(0.786)\end{array}$ & & & & $\begin{array}{c}-0.934 \\
(0.905)\end{array}$ & & & & $\begin{array}{c}1.218^{\star \star \star} \\
(0.171)\end{array}$ & & & & $\begin{array}{l}1.248^{\star \star} \\
(0.649)\end{array}$ & & \\
\hline ecdist & & & $\begin{array}{c}-0.101 \\
(0.375)\end{array}$ & & & & $\begin{array}{l}-0.681 \\
(0.463)\end{array}$ & & & & $\begin{array}{c}0.341^{\star \star \star} \\
(0.117)\end{array}$ & & & & $\begin{array}{c}0.576^{\star \star \star} \\
(0.177)\end{array}$ & & & & $\begin{array}{l}-0.721 \\
(0.725) \\
\end{array}$ & & & & $\begin{array}{c}-2.024^{\star * \star} \\
(0.514) \\
\end{array}$ & \\
\hline ecdistthkdist & & & & $\begin{array}{c}1.692^{\star \star \star} \\
(0.203)\end{array}$ & & & & $\begin{array}{c}0.626^{\star \star \star} \\
(0.156)\end{array}$ & & & & $\begin{array}{l}0.396^{\star \star} \\
(0.177)\end{array}$ & & & & \begin{tabular}{|c}
$0.538^{\star \star \star}$ \\
$(0.182)$
\end{tabular} & & & & $\begin{array}{c}0.613 \\
(0.448)\end{array}$ & & & & $\begin{array}{c}-1.404^{* *} \\
(0.619)\end{array}$ \\
\hline hkpci & $\begin{array}{c}-0.613^{\star \star \star} \\
(0.179)\end{array}$ & & & & $\begin{array}{c}0.152 \\
(0.362)\end{array}$ & & & & $\begin{array}{c}0.113 \\
(0.420)\end{array}$ & & & & $\begin{array}{c}0.837^{\star \star \star} \\
(0.274)\end{array}$ & & & & $\begin{array}{c}-0.806 \\
(0.951)\end{array}$ & & & & $\begin{array}{c}-2.117^{*} \\
(1.112)\end{array}$ & & & \\
\hline hkpcj & \begin{tabular}{|c|}
0.503 \\
$(0.550)$
\end{tabular} & & & & $\begin{array}{c}-0.736 \\
(0.572)\end{array}$ & & & & $\begin{array}{c}-0.428 \\
(0.343) \\
\end{array}$ & & & & $\begin{array}{c}-4.177^{\star \star \star} \\
(0.614)\end{array}$ & & & & $\begin{array}{c}0.622 \\
(0.798)\end{array}$ & & & & $\begin{array}{c}-0.017 \\
(1.264) \\
\end{array}$ & & & \\
\hline hkdist & & & $\begin{array}{l}-0.025 \\
(0.067) \\
\end{array}$ & & & & $\begin{array}{c}0.046 \\
(0.072) \\
\end{array}$ & & & & $\begin{array}{l}-0.048 \\
(0.042) \\
\end{array}$ & & & & $\begin{array}{c}0.198^{\star * *} \\
(0.075) \\
\end{array}$ & & & & $\begin{array}{c}0.273 \\
(0.176) \\
\end{array}$ & & & & $\begin{array}{c}0.658^{\star \star \star} \\
(0.181) \\
\end{array}$ & \\
\hline disthkpci & & $\begin{array}{c}-1.894^{\star \star \star} \\
(0.324)\end{array}$ & & & & $\begin{array}{c}0.023 \\
(0.350) \\
\end{array}$ & & & & $\begin{array}{l}-0.535 \\
(0.588)\end{array}$ & & & & $\begin{array}{c}-1.376^{\star} \\
(0.825)\end{array}$ & & & & $\begin{array}{l}-1.411 \\
(1.127) \\
\end{array}$ & & & & $\begin{array}{c}0.463 \\
(2.372) \\
\end{array}$ & & \\
\hline disthkpcj & & $\begin{array}{l}-0.410 \\
(0.262)\end{array}$ & & & & $\begin{array}{c}-1.147^{\star \star \star} \\
(0.378)\end{array}$ & & & & $\begin{array}{c}-2.388^{\star \star \star \star} \\
(0.845)\end{array}$ & & & & $\begin{array}{c}-2.048^{\star \star \star \star} \\
(0.801)\end{array}$ & & & & $\begin{array}{c}0.315 \\
(0.746) \\
\end{array}$ & & & & $\begin{array}{c}-0.654 \\
(1.108) \\
\end{array}$ & & \\
\hline dist*hkdist & & & & $\begin{array}{c}-1.802^{\star \star \star} \\
(0.235)\end{array}$ & & & & $\begin{array}{c}-0.708^{\star \star \star} \\
(0.159)\end{array}$ & & & & $\begin{array}{c}-0.527^{\star \star \star} \\
(0.180)\end{array}$ & & & & $\begin{array}{l}-0.374^{*} \\
(0.214)\end{array}$ & & & & $\begin{array}{l}-0.370 \\
(0.386) \\
\end{array}$ & & & & $\begin{array}{c}1.789^{\star \star *} \\
(0.555)\end{array}$ \\
\hline dist & $\begin{array}{c}-2.515^{\star \star \star} \\
(0.299)\end{array}$ & & $\begin{array}{c}-2.570^{\star \star \star} \\
(0.284)\end{array}$ & & $\begin{array}{c}-0.984^{\star \star \star} \\
(0.171)\end{array}$ & & $\begin{array}{c}-1.442^{\star \star \star} \\
(0.120)\end{array}$ & & $\begin{array}{c}-3.045^{\star \star \star} \\
(0.648)\end{array}$ & & $\begin{array}{c}-3.211^{* * *} \\
(0.559)\end{array}$ & & $\begin{array}{c}-2.800^{\star \star \star} \\
(0.567)\end{array}$ & & $\begin{array}{c}-2.984^{* \star} \\
(1.429)\end{array}$ & & $\begin{array}{c}-1.173^{\star \star} \\
(0.555)\end{array}$ & & $\begin{array}{c}-0.770^{\star \star} \\
(0.396)\end{array}$ & & $\begin{array}{c}-0.325 \\
(1.489)\end{array}$ & & $\begin{array}{c}0.371 \\
(0.498)\end{array}$ & \\
\hline border & $\begin{array}{l}-0.514 \\
(0.394)\end{array}$ & $\begin{array}{l}-0.219 \\
(0.307)\end{array}$ & $\begin{array}{l}-0.642^{\star} \\
(0.384)\end{array}$ & $\begin{array}{c}.924^{\star \star \star} \\
(0.326)\end{array}$ & $\begin{array}{l}1.520^{* \star \star} \\
(0.444)\end{array}$ & $\begin{array}{l}1.292^{\star \star} \\
(0.568)\end{array}$ & $\begin{array}{l}0.690^{*} \\
(0.392) \\
\end{array}$ & $\begin{array}{c}2.477^{\star \star \star} \\
(0.719)\end{array}$ & \begin{tabular}{|c}
$-0.590^{* *}$ \\
$(0.280)$ \\
\end{tabular} & $\begin{array}{c}-0.589^{\star \star} \\
(0.271)\end{array}$ & $\begin{array}{c}-0.665^{\star *} \\
(0.333)\end{array}$ & $\begin{array}{c}0.134 \\
(0.343) \\
\end{array}$ & $\begin{array}{c}-1.090^{\star \star \star \star} \\
(0.360)\end{array}$ & $\begin{array}{c}-1.120^{\star \star \star} \\
(0.373) \\
\end{array}$ & $\begin{array}{l}-1.230 \\
(0.902) \\
\end{array}$ & $\begin{array}{c}-0.472 \\
(0.510) \\
\end{array}$ & $\begin{array}{c}2.230^{\star \star \star} \\
(0.760)\end{array}$ & $\begin{array}{l}1.800^{\star \star} \\
(0.767)\end{array}$ & $\begin{array}{l}2.562^{\star \star \star} \\
(0.426)\end{array}$ & $\begin{array}{c}3.070^{\star \star \star} \\
(0.535)\end{array}$ & $\begin{array}{c}2.472 \\
(2.313) \\
\end{array}$ & $\begin{array}{c}2.333 \\
(2.431) \\
\end{array}$ & $\begin{array}{c}2.284^{\star \star \star} \\
(0.877) \\
\end{array}$ & $\begin{array}{l}4.207^{\star \star \star} \\
(1.034)\end{array}$ \\
\hline EA & $\begin{array}{l}0.595^{\star * \star} \\
(0.153)\end{array}$ & $\begin{array}{l}0.586^{\star \star \star} \\
(0.152)\end{array}$ & $\begin{array}{l}0.607^{* k} \\
(0.144)\end{array}$ & $\begin{array}{l}0.553^{\star \star \star} \\
(0.133)\end{array}$ & $\begin{array}{c}0.509^{* \star \star} \\
(0.195)\end{array}$ & $\begin{array}{l}0.495^{* \star} \star \\
(0.194)\end{array}$ & $\begin{array}{c}0.583^{* \star *} \\
(0.187)\end{array}$ & $\begin{array}{c}0.540^{\star \star \star} \\
(0.185)\end{array}$ & & & & & & & & & $\begin{array}{c}0.296 \\
(0.255)\end{array}$ & $\begin{array}{c}0.288 \\
(0.246) \\
\end{array}$ & $\begin{array}{l}0.559 * \star \\
(0.233)\end{array}$ & $\begin{array}{c}0.372 \\
(0.233) \\
\end{array}$ & $\begin{array}{c}1.003^{\star \star \star} \\
(0.276) \\
\end{array}$ & $\begin{array}{c}1.097 \star \star \star \\
(0.287) \\
\end{array}$ & \begin{tabular}{|c|}
$0.989 * \star \star$ \\
$(0.274)$ \\
\end{tabular} & $\begin{array}{c}0.969^{\star \star \star} \\
(0.265) \\
\end{array}$ \\
\hline EURO & & & & & & & & & $\begin{array}{l}0.316^{\star *} \\
(0.163)\end{array}$ & $\begin{array}{l}0.265^{*} \\
(0.161)\end{array}$ & $\begin{array}{l}0.315^{\star \star} \\
(0.137)\end{array}$ & $\begin{array}{l}0.333^{* \star} \\
(0.143)\end{array}$ & $\begin{array}{c}-0.012 \\
(0.258)\end{array}$ & $\begin{array}{c}0.323 \\
(0.259)\end{array}$ & $\begin{array}{c}0.014 \\
(0.218)\end{array}$ & $\begin{array}{c}0.040 \\
(0.226)\end{array}$ & & & & & & & & \\
\hline constant & $\begin{array}{c}-13.199 * \star \\
(6.108)\end{array}$ & $\begin{array}{c}-23.828^{\star \star \star} \\
(3.688)\end{array}$ & $\begin{array}{l}-5.044 \\
(4.752)\end{array}$ & $\begin{array}{c}-26.620^{\star \star \star} \\
(1.371)\end{array}$ & $\begin{array}{c}-31.529^{\star \star \star} \\
(7.646)\end{array}$ & $\begin{array}{c}-25.167^{\star \star \star} \\
(3.313)\end{array}$ & \begin{tabular}{|c|}
$-6.562^{\star \star \star}$ \\
$(5.197)$ \\
\end{tabular} & $\begin{array}{c}-27.212^{\star \star \star} \\
(1.362) \\
\end{array}$ & \begin{tabular}{|c}
19.922 \\
$(12.944)$ \\
\end{tabular} & $\begin{array}{c}12.552^{\star *} \\
(5.727)\end{array}$ & $\begin{array}{c}28.556^{\star \star \star} \\
(8.631) \\
\end{array}$ & $\begin{array}{c}-7.705^{*} \\
(4.141)\end{array}$ & \begin{tabular}{|c|}
$-66.085^{\star \star \star}$ \\
$(14.194)$ \\
\end{tabular} & $\begin{array}{c}-14.108^{\star \star \star} \\
(2.968)\end{array}$ & \begin{tabular}{|l}
-14.883 \\
$(10.528)$ \\
\end{tabular} & $\begin{array}{c}-48.054^{\star \star \star} \\
(7.602)\end{array}$ & \begin{tabular}{|c|}
$-53.000^{\star \star \star}$ \\
$(18.017)$
\end{tabular} & $\begin{array}{c}-22.052^{\star \star \star} \\
(7.933)\end{array}$ & \begin{tabular}{|l}
-5.760 \\
$(9.274)$ \\
\end{tabular} & $\begin{array}{l}-10.075 \\
(8.758)\end{array}$ & $\begin{array}{c}-44.085^{\star \star \star} \\
(20.446)\end{array}$ & \begin{tabular}{|l}
$-25.263^{\star}$ \\
$(14.282)$ \\
\end{tabular} & $\begin{array}{c}-19.665^{\star \star} \\
(8.624) \\
\end{array}$ & $\begin{array}{c}-26.378^{\star \star \star} \\
(10.352)\end{array}$ \\
\hline No obs & 844 & \begin{tabular}{|l|l|}
844 \\
\end{tabular} & 844 & 844 & 865 & 865 & \begin{tabular}{|l|l|}
865 \\
\end{tabular} & 865 & 320 & 320 & 320 & 320 & 318 & 318 & 318 & 318 & 226 & 226 & 226 & 226 & 219 & 219 & 219 & 219 \\
\hline $\mathrm{R} 2$ & 0.9621 & 0.9599 & 0.9598 & 0.954 & 0.952 & 0.952 & 0.952 & 0.956 & 0.982 & 0.982 & 0.978 & 0.972 & 0.979 & 0.979 & 0.979 & 0.976 & 0.9363 & 0.9336 & 0.9476 & 0.9347 & 0.851 & 0.869 & 0.884 & 0.885 \\
\hline Wald Chi2 & $2890.44^{* * *}$ & $1946.36^{* \star *}$ & $1797^{\star \star \star}$ & $1221.97^{* \star *}$ & $4203.49^{* \star *}$ & $2492.67^{* \star *}$ & $2020.68^{* \star *}$ & $1561.35^{* \star *}$ & $2003.04^{* * *}$ & $1928.10^{* \star *}$ & $856.18^{\star \star \star}$ & $449.71^{\star * \star}$ & $1266.09^{* \star *}$ & $1417.04^{* \star \star *}$ & $718.97^{\star \star \star}$ & $499.56^{\star \star \star}$ & $600.83^{\star \star *}$ & $800^{\star \star \star}$ & $784.3^{* \star \star}$ & $544.78^{\star \star \star}$ & \begin{tabular}{|l|}
$52.21^{* * *}$ \\
\end{tabular} & $64.49^{* \star \star}$ & $57.11^{* * *}$ & $44.56^{\star \star \star}$ \\
\hline
\end{tabular}




\begin{tabular}{|c|c|c|c|c|c|c|c|c|c|c|c|c|c|c|c|c|c|c|c|c|c|c|c|c|}
\hline \multirow{3}{*}{ Machinery } & \multicolumn{8}{|c|}{ North-East } & \multicolumn{8}{|c|}{ North-South } & \multicolumn{8}{|c|}{ South-East } \\
\hline & \multicolumn{4}{|c|}{ Dependent Variable: Export Value } & \multicolumn{4}{|c|}{ Dependent Variable: Import Value } & \multicolumn{4}{|c|}{ Dependent Variable: Export Value } & \multicolumn{4}{|c|}{ Dependent Variable: Import Value } & \multicolumn{4}{|c|}{ Dependent Variable: Export Value } & \multicolumn{4}{|c|}{\begin{tabular}{|l|} 
Dependent Variable: Import Value \\
\end{tabular}} \\
\hline & \begin{tabular}{|l|} 
Model 1 \\
\end{tabular} & \begin{tabular}{|l|} 
Model 2 \\
\end{tabular} & \begin{tabular}{|l|} 
Model 3 \\
\end{tabular} & Model 4 & Model 1 & \begin{tabular}{|l|} 
Model 2 \\
\end{tabular} & Model 3 & Model 4 & \begin{tabular}{|l|} 
Model 1 \\
\end{tabular} & \begin{tabular}{|l|} 
Model 2 \\
\end{tabular} & \begin{tabular}{|l|} 
Model 3 \\
\end{tabular} & Model 4 & \begin{tabular}{l|l} 
Model 1 \\
\end{tabular} & \begin{tabular}{|l|l|} 
Model 2 \\
\end{tabular} & \begin{tabular}{|l|} 
Model 3 \\
\end{tabular} & Model 4 & Model 1 & Model 2 & Model 3 & Model 4 & Model 1 & \begin{tabular}{|l|} 
Model 2 \\
\end{tabular} & Model 3 & Model 4 \\
\hline popi & $\begin{array}{l}0.946^{\star \star \star} \\
(0.052)\end{array}$ & \begin{tabular}{c|}
$0.927^{\star \star \star}$ \\
$(0.050)$
\end{tabular} & $\begin{array}{c}0.938^{\star \star \star} \\
(0.059)\end{array}$ & $\begin{array}{c}0.931^{* \star \star} \\
(0.058)\end{array}$ & $\begin{array}{l}1.140^{* \star \star} \\
(0.074)\end{array}$ & \begin{tabular}{|c|}
$1.119^{\star \star \star}$ \\
$(0.069)$
\end{tabular} & $\begin{array}{l}1.149^{* \star \star} \\
(0.098)\end{array}$ & $\begin{array}{c}1.010^{\star \star \star} \\
(0.079)\end{array}$ & $\begin{array}{l}1.047^{* k \star} \\
(0.044)\end{array}$ & $\begin{array}{l}1.042^{* k \star} \\
(0.035)\end{array}$ & $\begin{array}{l}0.995^{\star k \star} \\
(0.025)\end{array}$ & $\begin{array}{l}1.007^{* \star \star} \\
(0.028)\end{array}$ & $\begin{array}{l}1.222^{* \star \star \star} \\
(0.071)\end{array}$ & $\begin{array}{l}1.135^{* \star \star} \\
(0.044)\end{array}$ & $\begin{array}{c}1.075^{* \star \star} \\
(0.060)\end{array}$ & $\begin{array}{c}1.038^{\star \star \star} \\
(0.057)\end{array}$ & $\begin{array}{c}0.048 \\
(0.535)\end{array}$ & \begin{tabular}{|c|}
$1.906^{\star \star \star}$ \\
$(0.182)$
\end{tabular} & \begin{tabular}{|c|}
$2.665^{* \star \star}$ \\
$(0.204)$
\end{tabular} & $\begin{array}{c}2.393^{\star \star \star} \\
(0.236)\end{array}$ & $\begin{array}{c}-1.994^{\star \star \star} \\
(0.723)\end{array}$ & $\begin{array}{l}-0.052 \\
(0.256)\end{array}$ & $\begin{array}{c}1.825^{\star \star \star} \\
(0.465)\end{array}$ & \begin{tabular}{|c|}
0.201 \\
$(0.825)$
\end{tabular} \\
\hline popj & $\begin{array}{l}1.318^{\star \star \star} \\
(0.111)\end{array}$ & $\begin{array}{l}1.260^{\star \star \star} \\
(0.118)\end{array}$ & $\begin{array}{c}0.790^{\star \star \star} \\
(0.098)\end{array}$ & $\begin{array}{c}0.833^{\star \star \star} \\
(0.121)\end{array}$ & $\begin{array}{l}1.921^{\star \star \star} \\
(0.182)\end{array}$ & \begin{tabular}{|c|}
$1.921^{* \star \star}$ \\
$(0.184)$
\end{tabular} & $\begin{array}{l}1.391^{\star \star \star} \\
(0.108)\end{array}$ & $\begin{array}{c}1.434^{\star \star * k} \\
(0.103)\end{array}$ & $\begin{array}{l}-0.164 \\
(0.204)\end{array}$ & $\begin{array}{l}0.732^{* k+} \\
(0.114)\end{array}$ & $\begin{array}{l}1.290^{* \star \star} \\
(0.050)\end{array}$ & $\begin{array}{l}1.318^{\star \star \star} \\
(0.047)\end{array}$ & $\begin{array}{c}0.072 \\
(0.335)\end{array}$ & \begin{tabular}{|c|}
$1.355^{\star \star *}$ \\
$(0.103)$
\end{tabular} & \begin{tabular}{|c|}
$1.933^{\star * \star}$ \\
$(0.087)$ \\
\end{tabular} & $\begin{array}{c}1.791^{\star \star \star} \\
(0.055)\end{array}$ & $\begin{array}{c}0.839^{\star \star \star} \\
(0.139)\end{array}$ & \begin{tabular}{|c|}
$1.173^{\star \star \star}$ \\
$(0.132)$
\end{tabular} & \begin{tabular}{|l|}
$0.838^{* \star \star}$ \\
$(0.102)$
\end{tabular} & $\begin{array}{c}1.002^{\star \star \star} \\
(0.125)\end{array}$ & \begin{tabular}{|c|}
$1.961^{\star \star *}$ \\
$(0.186)$
\end{tabular} & $\begin{array}{c}2.339^{\star \star \star} \\
(0.217)\end{array}$ & \begin{tabular}{|c|}
$2.045^{\star \star \star}$ \\
$(0.256)$
\end{tabular} & $\begin{array}{c}2.365^{\star \star \star} \\
(0.435)\end{array}$ \\
\hline gdppci & $\begin{array}{c}1.471^{\star \star \star} \\
(0.409)\end{array}$ & & & & $\begin{array}{l}1.701^{* \star} \\
(0.461)\end{array}$ & & & & $\begin{array}{l}0.894^{\star \star \star} \\
(0.264)\end{array}$ & & & & $\begin{array}{c}0.267 \\
(0.397)\end{array}$ & & & & $\begin{array}{l}9.708^{\star \star \star} \\
(2.162)\end{array}$ & & & & \begin{tabular}{|c|}
$10.595^{\star \star \star}$ \\
$(2.880)$
\end{tabular} & & & \\
\hline gdppcj & $\begin{array}{l}0.960^{* \star \star} \\
(0.180)\end{array}$ & & & & $\begin{array}{l}2.050^{* k *} \\
(0.232)\end{array}$ & & & & $\begin{array}{l}5.003^{\star \star \star} \\
(0.863)\end{array}$ & & & & $\begin{array}{l}6.844^{\star \star \star} \\
(1.353)\end{array}$ & & & & $\begin{array}{l}0.800^{\star \star \star} \\
(0.231)\end{array}$ & & & & $\begin{array}{c}1.940^{\star \star \star} \\
(0.327)\end{array}$ & & & \\
\hline gdppcihkpc & & $\begin{array}{c}1.928^{\star \star \star} \\
(0.306)\end{array}$ & & & & $\begin{array}{c}1.472^{\star \star \star} \\
(0.245)\end{array}$ & & & & \begin{tabular}{|c|}
$0.694^{\star \star *}$ \\
$(0.212)$
\end{tabular} & & & & $\begin{array}{c}0.114 \\
(0.320)\end{array}$ & & & & \begin{tabular}{|c|}
$2.342^{\star \star \star}$ \\
$(0.576)$
\end{tabular} & & & & $\begin{array}{c}2.186^{\star \star \star} \\
(0.562)\end{array}$ & & \\
\hline gdppcj*hkpc & & $\begin{array}{c}0.976^{\star \star \star} \\
(0.174)\end{array}$ & & & & $\begin{array}{c}2.045^{\star \star \star} \\
(0.236)\end{array}$ & & & & $\begin{array}{l}0.875^{\star \star} \\
(0.364)\end{array}$ & & & & $\begin{array}{c}0.757 \\
(0.506)\end{array}$ & & & & $\begin{array}{l}1.063^{\star \star \star} \\
(0.219)\end{array}$ & & & & $\begin{array}{c}2.402 \star \star \star \\
(0.365)\end{array}$ & & \\
\hline ecdist & & & $\begin{array}{l}0.944^{*} \\
(0.494)\end{array}$ & & & & $\begin{array}{c}1.575^{\star \star \star} \\
(0.526)\end{array}$ & & & & \begin{tabular}{c|}
$0.289^{\star \star \star}$ \\
$(0.070)$
\end{tabular} & & & & \begin{tabular}{|c|}
$0.225^{\star \star \star}$ \\
$(0.066)$
\end{tabular} & & & & $\begin{array}{c}-0.915^{\star \star \star} \\
(0.346)\end{array}$ & & & & \begin{tabular}{|c|}
$-3.210^{\star \star \star}$ \\
$(0.512)$
\end{tabular} & \\
\hline $\begin{array}{l}\text { ecdist*nkdis } \\
t\end{array}$ & & & & $\begin{array}{l}1.503^{\star \star \star} \\
(0.181) \\
\end{array}$ & & & & $\begin{array}{l}1.048^{\star \star *} \\
(0.220)\end{array}$ & & & & $\begin{array}{c}0.280^{\star \star \star} \\
(0.072)\end{array}$ & & & & \begin{tabular}{|c|}
$0.227^{\star \star \star}$ \\
$(0.067)$
\end{tabular} & & & & $\begin{array}{l}-0.952^{*} \\
(0.524)\end{array}$ & & & & $\begin{array}{c}0.736 \\
(2.111) \\
\end{array}$ \\
\hline hkpci & \begin{tabular}{|c|}
$0.361^{\star \star \star}$ \\
$(0.145)$
\end{tabular} & & & & $\begin{array}{l}0.489^{\star \star \star} \\
(0.158)\end{array}$ & & & & $\begin{array}{l}0.409^{* \star} \\
(0.178)\end{array}$ & & & & $\begin{array}{l}0.707^{\star \star \star} \\
(0.187)\end{array}$ & & & & $\begin{array}{c}-1.176^{* \star *} \\
(0.411)\end{array}$ & & & & $\begin{array}{c}-3.812^{\star \star \star} \\
(1.044)\end{array}$ & & & \\
\hline hkpcj & $\begin{array}{l}1.778^{\star \star \star} \\
(0.284)\end{array}$ & & & & $\begin{array}{c}1.831^{\star \star \star} \\
(0.369) \\
\end{array}$ & & & & $\begin{array}{c}-1.119^{\star \star *} \\
(0.180)\end{array}$ & & & & $\begin{array}{c}-2.123^{\star \star \star} \\
(0.288)\end{array}$ & & & & \begin{tabular}{|l|}
-0.154 \\
$(0.740)$
\end{tabular} & & & & $\begin{array}{l}1.814^{\star \star \star} \\
(0.495)\end{array}$ & & & \\
\hline hkdist & & & $\begin{array}{l}-0.060 \\
(0.051)\end{array}$ & & & & $\begin{array}{c}0.067 \\
(0.067)\end{array}$ & & & & $\begin{array}{l}-0.041 \\
(0.028)\end{array}$ & & & & $\begin{array}{c}0.018 \\
(0.047) \\
\end{array}$ & & & & \begin{tabular}{|c|}
$0.165^{\star \star \star}$ \\
$(0.068)$ \\
\end{tabular} & & & & $\begin{array}{c}0.724^{\star \star \star \star} \\
(0.132) \\
\end{array}$ & \\
\hline distnkpci & & $\begin{array}{c}-1.850^{\star \star \star} \\
(0.275)\end{array}$ & & & & \begin{tabular}{|c|}
$-0.891 * \star *$ \\
$(0.315)$
\end{tabular} & & & & $\begin{array}{c}0.126 \\
(0.292)\end{array}$ & & & & $\begin{array}{l}1.323^{\star \star \star} \\
(0.454)\end{array}$ & & & & $\begin{array}{c}-2.739 * \star \star \\
(0.791)\end{array}$ & & & & \begin{tabular}{|c|}
$-4.996^{\star \star \star}$ \\
$(0.672)$
\end{tabular} & & \\
\hline dist*hkpcj & & $\begin{array}{l}0.563^{* \star} \\
(0.279)\end{array}$ & & & & $\begin{array}{l}-0.026 \\
(0.297)\end{array}$ & & & & $\begin{array}{c}-1.270^{\star \star \star} \\
(0.372)\end{array}$ & & & & $\begin{array}{c}-2.083^{\star \star \star} \\
(0.419)\end{array}$ & & & & $\begin{array}{c}0.635 \\
(0.604)\end{array}$ & & & & $\begin{array}{l}0.870^{\star} \\
(0.466)\end{array}$ & & \\
\hline dist*hkdist & & & & \begin{tabular}{|c|}
$-1.560^{\star \star \star}$ \\
$(0.184)$
\end{tabular} & & & & \begin{tabular}{|c|}
$-0.975^{\star \star \star}$ \\
$(0.231)$ \\
\end{tabular} & & & & $\begin{array}{c}-0.330^{\star \star \star} \\
(0.085)\end{array}$ & & & & $\begin{array}{l}-0.195^{\star \star} \\
(0.097)\end{array}$ & & & & $\begin{array}{l}0.764^{*} \\
(0.445)\end{array}$ & & & & \begin{tabular}{|c|}
-0.054 \\
$(2.148)$
\end{tabular} \\
\hline dist & $\begin{array}{c}-1.418^{\star \star \star} \\
(0.220)\end{array}$ & & $\begin{array}{c}-1.754^{\star \star \star} \\
(0.195)\end{array}$ & & $\begin{array}{c}-0.840^{\star \star} \\
(0.434)\end{array}$ & & $\begin{array}{l}-0.766^{*} \\
(0.412)\end{array}$ & & $\begin{array}{c}-0.543^{\star \star \star} \\
(0.190)\end{array}$ & & $\begin{array}{c}-0.595^{\star * \star} \\
(0.179)\end{array}$ & & $\begin{array}{l}-0.319 \\
(0.233)\end{array}$ & & $\begin{array}{c}0.236 \\
(0.213)\end{array}$ & & $\begin{array}{c}-2.021^{\star * \star} \\
(0.307)\end{array}$ & & $\begin{array}{c}-1.732^{\star \star \star} \\
(0.257)\end{array}$ & & $\begin{array}{c}-4.608^{\star \star \star} \\
(0.736)\end{array}$ & & $\begin{array}{c}2.172^{\star \star \star} \\
(0.862)\end{array}$ & \\
\hline border & $\begin{array}{c}0.699^{\star \star \star} \\
(0.278)\end{array}$ & $\begin{array}{c}0.828^{\star \star \star} \\
(0.233)\end{array}$ & $\begin{array}{c}-0.018 \\
(0.254)\end{array}$ & $\begin{array}{l}0.485^{* \star} \\
(0.237)\end{array}$ & $\begin{array}{c}2.314^{\star \star \star} \\
(0.673)\end{array}$ & \begin{tabular}{|c|}
$2.073^{\star \star \star}$ \\
$(0.557)$
\end{tabular} & $\begin{array}{c}3.120^{\star \star \star *} \\
(0.650)\end{array}$ & \begin{tabular}{|c|}
$2.457^{\star \star \star}$ \\
$(0.353)$
\end{tabular} & $\begin{array}{c}0.067 \\
(0.155)\end{array}$ & $\begin{array}{c}0.002 \\
(0.105)\end{array}$ & $\begin{array}{c}-0.204^{\star \star} \\
(0.088)\end{array}$ & $\begin{array}{c}-0.103 \\
(0.076)\end{array}$ & $\begin{array}{l}0.470^{\star *} \\
(0.245)\end{array}$ & \begin{tabular}{c|}
$0.721^{\star \star \star}$ \\
$(0.134)$
\end{tabular} & \begin{tabular}{|c|}
$0.828^{\star \star \star}$ \\
$(0.083)$
\end{tabular} & \begin{tabular}{|c|}
$0.740^{\star \star \star}$ \\
$(0.089)$
\end{tabular} & $\begin{array}{l}1.301^{* *} \\
(0.615)\end{array}$ & $\begin{array}{c}0.346 \\
(0.567)\end{array}$ & \begin{tabular}{|c|}
$1.081^{\star \star \star}$ \\
$(0.430)$
\end{tabular} & $\begin{array}{c}4.687^{\star \star \star} \\
(0.964)\end{array}$ & $\begin{array}{c}-2.942^{\star \star \star} \\
(0.732)\end{array}$ & $\begin{array}{c}-2.903^{\star \star \star} \\
(0.478)\end{array}$ & $\begin{array}{c}-0.500 \\
(1.495)\end{array}$ & $\begin{array}{c}1.954 \\
(3.602)\end{array}$ \\
\hline EA & $\begin{array}{c}.727^{* k} \\
(0.153)\end{array}$ & $\begin{array}{l}0.730^{\star \star \star} \\
(0.149)\end{array}$ & $\begin{array}{c}0.876^{\star k \star} \\
(0.189)\end{array}$ & $\begin{array}{l}0.821^{\star \star} \\
(0.188)\end{array}$ & $\begin{array}{l}0.610^{\star \star \star} \\
(0.145)\end{array}$ & \begin{tabular}{|c|}
$0.633^{\star \star \star}$ \\
$(0.147)$
\end{tabular} & $\begin{array}{c}0.802^{* \star \star} \\
(0.162)\end{array}$ & \begin{tabular}{|c|}
$0.813^{\star \star \star}$ \\
$(0.169)$
\end{tabular} & & & & & & & & & $\begin{array}{l}1.156^{\star \star \star} \\
(0.202)\end{array}$ & $\begin{array}{c}1.231 * \star \star \\
(0.211) \\
\end{array}$ & \begin{tabular}{|c|}
$1.5277^{* \star \star}$ \\
$(0.191)$ \\
\end{tabular} & $\begin{array}{c}1.359^{* \star \star *} \\
(0.212) \\
\end{array}$ & $\begin{array}{c}0.141 \\
(0.206)\end{array}$ & $\begin{array}{c}0.306 \\
(0.227)\end{array}$ & $\begin{array}{l}0.463^{* \star} \\
(0.227)\end{array}$ & $\begin{array}{c}0.387 \\
(0.253) \\
\end{array}$ \\
\hline EURO & & & & & & & & & $\begin{array}{c}-0.035 \\
(0.076)\end{array}$ & $\begin{array}{l}0.197^{\star \star} \\
(0.091)\end{array}$ & \begin{tabular}{|c|}
$0.270^{\star \star \star}$ \\
$(0.096)$
\end{tabular} & $\begin{array}{c}0.274^{\star \star *} \\
(0.097)\end{array}$ & $\begin{array}{l}-0.027 \\
(0.109)\end{array}$ & $\begin{array}{l}0.349^{\star *} \\
(0.151)\end{array}$ & $\begin{array}{l}0.273^{* *} \\
(0.133)\end{array}$ & \begin{tabular}{|c|}
$0.277^{\star \star}$ \\
$(0.135)$
\end{tabular} & & & & & & & & \\
\hline constant & $\begin{array}{c}-26.176^{* \star \star} \\
(6.890)\end{array}$ & $\begin{array}{c}-32.096^{* \star \star} \\
(4.664)\end{array}$ & $\begin{array}{l}-8.846 \\
(6.692)\end{array}$ & $\begin{array}{c}-16.329^{* \star \star \star} \\
(2.602)\end{array}$ & $\begin{array}{c}-54.807 * \star \\
(9.506)\end{array}$ & \begin{tabular}{|c|}
$-50.836^{\star \star \star}$ \\
$(4.233)$
\end{tabular} & $\begin{array}{c}-36.403^{\star \star \star} \\
(8.850)\end{array}$ & \begin{tabular}{|c|}
$-27.950^{\star \star \star \star}$ \\
$(2.077)$
\end{tabular} & $\begin{array}{c}-49.544^{\star \star \star \star} \\
(5.231)\end{array}$ & $\begin{array}{c}-15.514^{\star \star \star \star} \\
(0.964)\end{array}$ & $\begin{array}{c}-16.776^{\star \star \star} \\
(1.630)\end{array}$ & $\begin{array}{c}-19.383^{* \star \star} \\
0.752)\end{array}$ & $\begin{array}{c}-73.127^{\star \star \star} \\
(8.921)\end{array}$ & $\begin{array}{c}-26.250^{* * \star} \\
(1.448)\end{array}$ & $\begin{array}{c}-36.033^{* \star \star} \\
(3.384)\end{array}$ & $\begin{array}{c}-29.752^{* \star \star} \\
(1.415)\end{array}$ & \begin{tabular}{|c|}
$-86.894^{\star \star \star}$ \\
$(12.279)$
\end{tabular} & $\begin{array}{c}-47.528^{\star \star \star} \\
(4.710)\end{array}$ & \begin{tabular}{|c|}
$-22.006^{\star \star \star \star ~}$ \\
$(2.688)$
\end{tabular} & $\begin{array}{c}-40.119^{\star \star \star} \\
4.622)\end{array}$ & $\begin{array}{c}-70.290^{* \star \star} \\
(15.811)\end{array}$ & $\begin{array}{c}-29.543^{* \star \star} \\
(6.481)\end{array}$ & $\begin{array}{c}0.028 \\
(9.888)\end{array}$ & \begin{tabular}{|c|}
$-30.791^{* *}$ \\
$(15.331)$
\end{tabular} \\
\hline No obs & 920 & 920 & 920 & 920 & 909 & 909 & 909 & 909 & 320 & 320 & 320 & 320 & 321 & 321 & 321 & 321 & 236 & 236 & 236 & 236 & 239 & 239 & 239 & 239 \\
\hline & 0.9858 & 0.9859 & 0.9772 & 0.9766 & 0.971 & \begin{tabular}{|l|l|}
0.974 \\
\end{tabular} & 0.964 & 0.965 & 0.998 & 0.998 & \begin{tabular}{|l|}
0.998 \\
\end{tabular} & 0.998 & 0.995 & \begin{tabular}{|l|l}
0.994 \\
\end{tabular} & 0.993 & 0.993 & 0.9698 & 0.9668 & 0.9661 & 0.9615 & 0.926 & 0.950 & 0.936 & 0.933 \\
\hline Wald Chi2 & $1472.36^{\star \star \star}$ & $1227.07^{* * *}$ & $3461.76^{* * *}$ & $3094.11^{* \star *}$ & $1281.95^{* * *}$ & $1836.61^{\star \star \star x}$ & \begin{tabular}{|c|}
$667.5^{\star \star *}$ \\
\end{tabular} & $820.64^{\star \star \star *}$ & $10159.06^{*}$ & $20836.64^{*}$ & $6042.44^{* \star *}$ & $4836.15^{\star * \star *}$ & $4853.60^{* \star \star x}$ & $11320.56^{*}$ & $15726.97^{*}$ & $14249.55^{*}$ & $5190.27^{* \star \star}$ & $4739.36^{* \star *}$ & $1124.98^{\star \star \star \star}$ & $427.5^{\star \star \star}$ & $670.01^{\star \star \star}$ & $431.15^{\star \star \star}$ & $573.07^{\star \star \star}$ & $282.19^{\star \star \star}$ \\
\hline
\end{tabular}




\begin{tabular}{|c|c|c|c|c|c|c|c|c|c|c|c|c|c|c|c|c|c|c|c|c|c|c|c|c|}
\hline \multirow{3}{*}{ Metals } & \multicolumn{8}{|c|}{ North-East } & \multicolumn{8}{|c|}{ North-South } & \multicolumn{8}{|c|}{ South-East } \\
\hline & \multicolumn{4}{|c|}{ Dependent Variable: Export Value } & \multicolumn{4}{|c|}{ Dependent Variable: Import Value } & \multicolumn{4}{|c|}{\begin{tabular}{|l|l|} 
Dependent Variable: Export Value \\
\end{tabular}} & \multicolumn{4}{|c|}{ Dependent Variable: Import Value } & \multicolumn{4}{|c|}{ Dependent Variable: Export Value } & \multicolumn{4}{|c|}{ Dependent Variable: Import Value } \\
\hline & Model 1 & Model 2 & Model 3 & Model 4 & Model 1 & 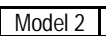 & Model 3 & Model 4 & Model 1 & 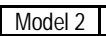 & 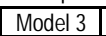 & Model 4 & Model 1 & \begin{tabular}{|l|} 
Model 2 \\
\end{tabular} & \begin{tabular}{|l|} 
Model 3 \\
\end{tabular} & Model 4 & Model 1 & Model 2 & Model 3 & Model 4 & Model 1 & \begin{tabular}{|l|} 
Model 2 \\
\end{tabular} & Model 3 & Model 4 \\
\hline popi & $\begin{array}{l}1.201^{\star \star \star} \\
(0.075)\end{array}$ & $\begin{array}{l}1.203^{\star \star \star} \\
(0.075)\end{array}$ & $\begin{array}{l}1.100^{\star \star \star} \\
(0.092)\end{array}$ & $\begin{array}{c}1.106^{\star \star \star} \\
(0.094)\end{array}$ & \begin{tabular}{c|}
$1.590^{* \star *}$ \\
$(0.084)$
\end{tabular} & $\begin{array}{c}1.591^{\star \star \star} \\
(0.083)\end{array}$ & $\begin{array}{l}1.538^{\star \star \star} \\
(0.082)\end{array}$ & $\begin{array}{c}1.531^{\star \star *} \\
(0.075)\end{array}$ & $\begin{array}{l}1.489^{* * \star} \\
(0.060)\end{array}$ & $\begin{array}{l}1.468^{\star \star \star} \\
(0.056)\end{array}$ & $\begin{array}{l}1.544^{\star \star \star} \\
(0.095)\end{array}$ & $\begin{array}{c}1.479^{\star \star \star} \\
(0.060)\end{array}$ & $\begin{array}{l}0.989^{* \star \star} \\
(0.035)\end{array}$ & $\begin{array}{c}1.002^{* \star *} \\
(0.032)\end{array}$ & $\begin{array}{l}1.052^{* \star \star} \\
(0.026)\end{array}$ & $\begin{array}{c}1.087^{* \star \star} \\
(0.027)\end{array}$ & \begin{tabular}{c|}
-0.960 \\
$(0.803)$
\end{tabular} & $\begin{array}{l}0.936^{\star *} \\
(0.485)\end{array}$ & \begin{tabular}{|c|}
$1.459^{\star \star \star}$ \\
$(0.377)$
\end{tabular} & $\begin{array}{c}1.246^{\star \star \star} \\
(0.473)\end{array}$ & $\begin{array}{c}-0.036 \\
(0.854)\end{array}$ & \begin{tabular}{c|}
0.131 \\
$(0.408)$
\end{tabular} & $\begin{array}{c}1.536^{* \star \star} \\
(0.584)\end{array}$ & \begin{tabular}{|c|}
0.450 \\
$(0.427)$
\end{tabular} \\
\hline popj & $\begin{array}{l}1.297^{\star \star \star} \\
(0.133)\end{array}$ & $\begin{array}{l}1.332^{\star \star \star} \\
(0.140)\end{array}$ & $\begin{array}{l}0.902^{\star \star \star} \\
(0.087)\end{array}$ & $\begin{array}{c}0.910^{\star \star \star} \\
(0.098)\end{array}$ & \begin{tabular}{c|}
$1.447^{* k *}$ \\
$(0.099)$
\end{tabular} & $\begin{array}{c}1.447^{\star \star \star} \\
(0.105)\end{array}$ & $\begin{array}{c}1.198^{\star \star \star} \\
(0.121)\end{array}$ & $\begin{array}{l}1.118^{\star \star \star} \\
(0.114)\end{array}$ & \begin{tabular}{|c|}
$1.261^{* \star *}$ \\
$(0.389)$
\end{tabular} & $\begin{array}{c}1.452^{\star \star \star} \\
(0.149)\end{array}$ & $\begin{array}{l}1.339^{\star \star \star} \\
(0.071)\end{array}$ & $\begin{array}{c}1.375^{\star \star \star} \\
(0.084)\end{array}$ & $\begin{array}{l}1.463^{* \star *} \\
(0.354)\end{array}$ & $\begin{array}{c}1.181^{* \star *} \\
(0.114)\end{array}$ & \begin{tabular}{c|}
$1.625^{\star \star *}$ \\
$(0.076)$
\end{tabular} & \begin{tabular}{|c|}
$1.660^{\star * \star}$ \\
$(0.073)$
\end{tabular} & \begin{tabular}{|c|}
$1.255^{\star \star k}$ \\
$(0.302)$
\end{tabular} & $\begin{array}{c}1.538^{\star \star \star} \\
(0.254)\end{array}$ & \begin{tabular}{|c|}
$0.962^{\star \star \star}$ \\
$(0.207)$
\end{tabular} & $\begin{array}{c}0.820^{\star \star \star} \\
(0.177)\end{array}$ & $\begin{array}{c}1.885^{\star \star \star} \\
(0.468)\end{array}$ & \begin{tabular}{|c|}
$1.830^{* \star *}$ \\
$(0.390)$
\end{tabular} & \begin{tabular}{|c|}
$1.573^{* \star \star}$ \\
$(0.297)$
\end{tabular} & $\begin{array}{c}1.492^{* \star \star} \\
(0.256)\end{array}$ \\
\hline gdppci & $\begin{array}{l}2.819^{\star \star \star} \\
(0.394)\end{array}$ & & & & \begin{tabular}{l|}
$1.681^{\star \star *}$ \\
$(0.523)$
\end{tabular} & & & & $\begin{array}{l}1.775^{\star \star \star} \\
(0.306)\end{array}$ & & & & $\begin{array}{l}0.450^{*} \\
(0.242)\end{array}$ & & & & \begin{tabular}{|c|}
$11.483^{\star \star \star}$ \\
$(2.939)$
\end{tabular} & & & & $\begin{array}{c}4.652 \\
(3.572)\end{array}$ & & & \\
\hline gdppcj & $\begin{array}{c}0.958^{\star * \star} \\
(0.239)\end{array}$ & & & & $\begin{array}{l}1.264^{* \star *} \\
(0.194)\end{array}$ & & & & $\begin{array}{c}-0.219 \\
(1.490)\end{array}$ & & & & $\begin{array}{c}-0.246 \\
(1.515)\end{array}$ & & & & \begin{tabular}{|c|}
0.206 \\
$(0.277)$
\end{tabular} & & & & $\begin{array}{c}1.169^{\star \star \star} \\
(0.420)\end{array}$ & & & \\
\hline gdppci*hkpci & & $\begin{array}{c}2.502^{\star \star \star} \\
(0.196)\end{array}$ & & & & $\begin{array}{c}1.701^{\star \star \star} \\
(0.345)\end{array}$ & & & & $\begin{array}{c}1.805^{\star \star \star} \\
(0.286)\end{array}$ & & & & $\begin{array}{c}0.456^{*} \\
(0.241)\end{array}$ & & & & $\begin{array}{c}3.321^{\star \star *} \\
(0.820)\end{array}$ & & & & $\begin{array}{c}3.976^{\star \star \star} \\
(0.816)\end{array}$ & & \\
\hline gdppcj*hkpci & & $\begin{array}{c}0.153^{\star \star \star} \\
(0.236)\end{array}$ & & & & $\begin{array}{l}1.263^{\star * \star} \\
(0.194)\end{array}$ & & & & $\begin{array}{c}-1.019^{* \star} \\
(0.466)\end{array}$ & & & & $\begin{array}{l}1.028^{\star \star \star} \\
(0.414)\end{array}$ & & & & $\begin{array}{c}0.488 \\
(0.319)\end{array}$ & & & & $\begin{array}{c}1.147^{\star \star \star} \\
(0.353)\end{array}$ & & \\
\hline ecdist & & & $\begin{array}{l}1.688^{\star \star \star} \\
(0.345)\end{array}$ & & & & $\begin{array}{l}0.890^{\star \star} \\
(0.387)\end{array}$ & & & & $\begin{array}{c}0.363^{\star \star \star} \\
(0.100)\end{array}$ & & & & \begin{tabular}{|c|}
$0.183^{\star \star \star}$ \\
$(0.060)$
\end{tabular} & & & & $\begin{array}{c}0.384 \\
(0.460)\end{array}$ & & & & $\begin{array}{c}-1.249^{\star \star \star} \\
(0.465)\end{array}$ & \\
\hline ecdistthkdist & & & & $\begin{array}{c}2.016^{\star \star \star} \\
(0.128)\end{array}$ & & & & $\begin{array}{c}1.542^{\star \star \star} \\
(0.119)\end{array}$ & & & & $\begin{array}{c}0.428^{\star \star \star} \\
(0.107)\end{array}$ & & & & $\begin{array}{c}0.173^{\star \star \star} \\
(0.047)\end{array}$ & & & & $\begin{array}{l}0.792^{\star} \\
(0.473)\end{array}$ & & & & $\begin{array}{c}2.151^{\star \star \star} \\
(0.549) \\
\end{array}$ \\
\hline hkpci & $\begin{array}{c}0.114 \\
(0.174)\end{array}$ & & & & $\begin{array}{c}0.793^{\star \star \star} \\
(0.210)\end{array}$ & & & & $\begin{array}{c}0.367 \\
(0.246)\end{array}$ & & & & $\begin{array}{c}0.821^{\star \star \star} \\
(0.173)\end{array}$ & & & & $\begin{array}{c}0.684 \\
(0.841)\end{array}$ & & & & $\begin{array}{l}-1.130 \\
(1.098)\end{array}$ & & & \\
\hline hkpcj & $\begin{array}{c}1.036^{\star \star \star} \\
(0.310)\end{array}$ & & & & $\begin{array}{c}0.433 \\
(0.440) \\
\end{array}$ & & & & $\begin{array}{l}-0.272 \\
(0.375) \\
\end{array}$ & & & & $\begin{array}{c}0.154 \\
(0.212) \\
\end{array}$ & & & & $\begin{array}{r}-0.228 \\
(1.000) \\
\end{array}$ & & & & $\begin{array}{l}1.762^{\star} \\
(0.971) \\
\end{array}$ & & & \\
\hline hkdist & & & $\begin{array}{l}0.067^{*} \\
(0.039)\end{array}$ & & & & $\begin{array}{c}-0.138^{\star \star \star} \\
(0.054)\end{array}$ & & & & $\begin{array}{c}0.015 \\
(0.039) \\
\end{array}$ & & & & $\begin{array}{c}-0.004 \\
(0.038) \\
\end{array}$ & & & & $\begin{array}{l}-0.117 \\
(0.145) \\
\end{array}$ & & & & $\begin{array}{c}0.074 \\
(0.170) \\
\end{array}$ & \\
\hline distnkpci & & $\begin{array}{c}-2.282^{\star \star \star} \\
(0.302)\end{array}$ & & & & \begin{tabular}{c|}
$-0.920^{\star \star \star}$ \\
$(0.282)$
\end{tabular} & & & & \begin{tabular}{|c|}
$-1.396^{\star \star \star}$ \\
$(0.329)$
\end{tabular} & & & & $\begin{array}{c}0.229 \\
(0.345)\end{array}$ & & & & $\begin{array}{l}-1.519 \\
(1.090)\end{array}$ & & & & $\begin{array}{c}-5.153^{\star \star \star} \\
(1.277)\end{array}$ & & \\
\hline dist*hkpcj & & $\begin{array}{c}0.204 \\
(0.273)\end{array}$ & & & & $\begin{array}{c}-0.843^{\star \star} \\
(0.376)\end{array}$ & & & & $\begin{array}{c}0.862 \\
(0.624)\end{array}$ & & & & $\begin{array}{c}-1.020^{\star \star \star} \\
(0.399)\end{array}$ & & & & $\begin{array}{c}0.667 \\
(0.747)\end{array}$ & & & & $\begin{array}{c}0.992 \\
(0.660)\end{array}$ & & \\
\hline dist*hkdist & & & & $\begin{array}{c}-1.973^{\star \star \star} \\
(0.134)\end{array}$ & & & & $\begin{array}{c}-1.754^{\star \star \star \star} \\
(0.101)\end{array}$ & & & & \begin{tabular}{|c|}
$-0.389^{\star \star \star}$ \\
$(0.114)$
\end{tabular} & & & & \begin{tabular}{|c|}
$-0.191^{\star \star \star}$ \\
$(0.062)$
\end{tabular} & & & & $\begin{array}{c}-1.051^{\star \star} \\
(0.452)\end{array}$ & & & & \begin{tabular}{|c|}
$-2.285^{\star \star \star}$ \\
$(0.495)$
\end{tabular} \\
\hline dist & $\begin{array}{c}-1.957^{\star \star \star} \\
(0.323)\end{array}$ & & $\begin{array}{c}2.136^{\star * \star} \\
(0.230)\end{array}$ & & $\begin{array}{c}-1.776^{\star \star \star} \\
(0.236)\end{array}$ & & $\begin{array}{c}-2.328^{\star \star \star} \\
(0.224)\end{array}$ & & $\begin{array}{c}-0.435 \\
(0.387) \\
\end{array}$ & & $\begin{array}{c}0.169 \\
(0.452)\end{array}$ & & $\begin{array}{c}-0.877^{\star \star \star} \\
(0.122)\end{array}$ & & \begin{tabular}{|c|}
$-0.454^{\star \star \star}$ \\
$(0.115)$ \\
\end{tabular} & & $\begin{array}{l}-1.133^{\star} \\
(0.640)\end{array}$ & & \begin{tabular}{|c|}
$-2.050^{\star \star \star}$ \\
$(0.431)$ \\
\end{tabular} & & $\begin{array}{c}-3.913^{\star \star \star} \\
(0.983)\end{array}$ & & $\begin{array}{c}-3.101^{\star \star \star} \\
(0.385)\end{array}$ & \\
\hline border & $\begin{array}{c}0.118 \\
(0.479)\end{array}$ & $\begin{array}{l}-0.087 \\
(0.326)\end{array}$ & $\begin{array}{l}-0.032 \\
(0.402)\end{array}$ & $\begin{array}{c}0.341 \\
(0.238)\end{array}$ & $\begin{array}{c}0.215 \\
(0.355)\end{array}$ & $\begin{array}{c}0.236 \\
(0.270)\end{array}$ & $\begin{array}{c}-0.439 \\
(0.306)\end{array}$ & $\begin{array}{c}0.674^{\star \star \star} \\
(0.165)\end{array}$ & $\begin{array}{c}-0.159 \\
(0.251)\end{array}$ & $\begin{array}{c}-0.169 \\
(0.224)\end{array}$ & $\begin{array}{c}0.100 \\
(0.208)\end{array}$ & $\begin{array}{c}-0.182 \\
(0.169)\end{array}$ & $\begin{array}{c}0.561^{* \star \star} \\
(0.094)\end{array}$ & \begin{tabular}{|c|}
$0.534^{\star \star \star}$ \\
$(0.094)$
\end{tabular} & $\begin{array}{l}0.349^{\star \star} \\
(0.149)\end{array}$ & $\begin{array}{l}0.420^{\star \star} \\
(0.176)\end{array}$ & $\begin{array}{c}2.406^{\star \star \star} \\
(0.950)\end{array}$ & $\begin{array}{l}1.884^{* *} \\
(0.903)\end{array}$ & \begin{tabular}{|c|}
$1.140^{*}$ \\
$(0.671)$
\end{tabular} & $\begin{array}{c}2.681^{\star \star \star} \\
(0.755)\end{array}$ & $\begin{array}{c}-1.515^{\star} \\
(0.907)\end{array}$ & $\begin{array}{c}-1.864^{* *} \\
(0.951)\end{array}$ & $\begin{array}{c}-0.215 \\
(0.509)\end{array}$ & $\begin{array}{c}0.668 \\
(1.001)\end{array}$ \\
\hline EA & $\begin{array}{l}0.763^{\star \star \star} \\
(0.178)\end{array}$ & $\begin{array}{l}0.769^{\star \star \star} \\
(0.180)\end{array}$ & $\begin{array}{l}0.898^{\star \star \star} \\
(0.188)\end{array}$ & $\begin{array}{c}0.883^{\star \star \star} \\
(0.187)\end{array}$ & $\begin{array}{c}0.219 \\
(0.169)\end{array}$ & $\begin{array}{c}0.220 \\
(0.169)\end{array}$ & $\begin{array}{l}0.400^{\star *} \\
(0.181)\end{array}$ & $\begin{array}{l}0.354^{* *} \\
(0.176)\end{array}$ & & & & & & & & & $\begin{array}{l}0.692^{* \star} \\
(0.291)\end{array}$ & \begin{tabular}{|c|}
$0.796 * \star \star \star$ \\
$(0.272)$ \\
\end{tabular} & \begin{tabular}{|c|c}
$1.369^{\star \star \star}$ \\
$(0.273)$
\end{tabular} & $\begin{array}{c}1.260^{\star \star \star} \\
(0.288)\end{array}$ & $\begin{array}{c}-0.202 \\
(0.333) \\
\end{array}$ & $\begin{array}{l}-0.208 \\
(0.318) \\
\end{array}$ & $\begin{array}{c}0.219 \\
(0.294)\end{array}$ & $\begin{array}{c}0.079 \\
(0.308) \\
\end{array}$ \\
\hline EURO & & & & & & & & & $\begin{array}{c}0.131 \\
(0.172)\end{array}$ & $\begin{array}{c}0.175 \\
(0.166)\end{array}$ & $\begin{array}{c}0.188 \\
(0.167)\end{array}$ & $\begin{array}{c}0.169 \\
(0.167)\end{array}$ & $\begin{array}{c}-0.039 \\
(0.124)\end{array}$ & $\begin{array}{c}-0.122 \\
(0.118)\end{array}$ & $\begin{array}{c}0.007 \\
(0.107)\end{array}$ & $\begin{array}{c}0.007 \\
(0.100)\end{array}$ & & & & & & & & \\
\hline constant & $\begin{array}{c}-44.557^{\star \star \star} \\
(7.813)\end{array}$ & $\begin{array}{c}-40.391^{\star \star \star} \\
(3.862)\end{array}$ & $\begin{array}{c}-19.447 * \star \\
(5.369)\end{array}$ & $\begin{array}{c}-24.225^{* \star \star} \\
(1.930)\end{array}$ & $\begin{array}{c}-44.782^{* \star \star} \\
(6.656)\end{array}$ & $\begin{array}{c}-45.163^{\star \star \star} \\
(4.104)\end{array}$ & $\begin{array}{c}-22.367^{\star \star \star} \\
(4.453)\end{array}$ & $\mid \begin{array}{c}-31.902^{* \star \star} \\
(2.032)\end{array}$ & $\mid \begin{array}{c}-40.109^{* \star \star} \\
(7.847)\end{array}$ & $\begin{array}{c}-34.482^{\star \star \star} \\
(3.271)\end{array}$ & $\begin{array}{c}-34.502^{\star \star \star} \\
(5.285)\end{array}$ & $\begin{array}{c}-30.296^{\star \star \star} \\
(2.054)\end{array}$ & $\begin{array}{c}-16.096^{*} \\
(9.524)\end{array}$ & $\begin{array}{c}-25.195^{\star \star \star} \\
(1.610)\end{array}$ & $\begin{array}{c}-25.377^{\star \star \star} \\
(2.391)\end{array}$ & $\begin{array}{c}-28.501^{\star \star \star \star} \\
(1.571)\end{array}$ & \begin{tabular}{|c|}
$-91.008^{\star \star \star}$ \\
$(18.023)$
\end{tabular} & $\begin{array}{c}-47.042^{2 \star \star} \\
(7.763)\end{array}$ & \begin{tabular}{|c|}
$-15.467^{\star *}$ \\
$(6.909)$
\end{tabular} & $\begin{array}{c}-21.681^{\star \star \star} \\
(7.816)\end{array}$ & 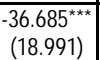 & $\begin{array}{c}-29.391 * \star \star \\
(9.337)\end{array}$ & $\begin{array}{c}-1.086 \\
(6.617)\end{array}$ & $\begin{array}{c}20.122^{* \star} \\
(9.289)\end{array}$ \\
\hline No obs & 911 & 911 & 911 & 911 & 902 & \begin{tabular}{|l|}
902 \\
\end{tabular} & $\begin{array}{l}902 \\
\end{array}$ & 902 & \begin{tabular}{|l|}
320 \\
\end{tabular} & \begin{tabular}{|c|}
320 \\
\end{tabular} & 320 & \begin{tabular}{|l|}
320 \\
\end{tabular} & 321 & \begin{tabular}{|c|}
321 \\
\end{tabular} & 321 & 321 & 234 & 234 & 234 & \begin{tabular}{|l|}
234 \\
\end{tabular} & 230 & 230 & 230 & 230 \\
\hline & \begin{tabular}{|l|}
0.9762 \\
\end{tabular} & 0.9763 & 0.9746 & \begin{tabular}{|l|}
0.9727 \\
\end{tabular} & \begin{tabular}{|l|}
0.969 \\
\end{tabular} & \begin{tabular}{|l|}
0.969 \\
\end{tabular} & 0.965 & \begin{tabular}{|l|}
0.964 \\
\end{tabular} & \begin{tabular}{|l|}
0.992 \\
\end{tabular} & \begin{tabular}{|l|}
0.992 \\
\end{tabular} & \begin{tabular}{|l|}
0.994 \\
\end{tabular} & \begin{tabular}{|l|}
0.994 \\
\end{tabular} & \begin{tabular}{|l|}
0.995 \\
\end{tabular} & \begin{tabular}{|l|}
0.996 \\
\end{tabular} & 0.995 & 0.995 & 0.8931 & 0.9028 & 0.9498 & \begin{tabular}{|l|}
0.9461 \\
\end{tabular} & 0.944 & 0.938 & 0.946 & 0.927 \\
\hline Wald Chi2 & $7034.91^{\star * \star *}$ & $6113.83^{\star \star \star}$ & $4822.65^{\star \star \star}$ & $5012.09^{\star \star \star}$ & $970.28^{\star \star \star}$ & \begin{tabular}{|l|}
$958.1^{\star \star \star}$ \\
\end{tabular} & $720.37^{\star \star \star}$ & $1070.55^{* k *}$ & $3340.77^{\star * \star *}$ & $3255.60^{\star * \star *}$ & $3803.73^{* * *}$ & $2742.38^{* \star *}$ & $9787.12^{2 \star *}$ & $\mid 10702.48^{\star}$ & $7916.79^{* \star *}$ & $5052.91^{\star \star \star}$ & $957.29^{\star \star \star}$ & $1263.38^{\star \star \star}$ & $2295.19^{\star \star \star x}$ & $1390.47^{\star \star \star *}$ & $436.68^{\star \star \star}$ & $439.5^{\star \star *}$ & $296.58^{\star \star \star *}$ & $289.06^{\star \star \star}$ \\
\hline
\end{tabular}




\begin{tabular}{|c|c|c|c|c|c|c|c|c|c|c|c|c|c|c|c|c|c|c|c|c|c|c|c|c|}
\hline \multirow{3}{*}{ Minerals } & \multicolumn{8}{|c|}{ North-East } & \multicolumn{8}{|c|}{ North-South } & \multicolumn{8}{|c|}{ South-East } \\
\hline & \multicolumn{4}{|c|}{ Dependent Variable: Export Value } & \multicolumn{4}{|c|}{ Dependent Variable: Import Value } & \multicolumn{4}{|c|}{ Dependent Variable: Export Value } & \multicolumn{4}{|c|}{ Dependent Variable: Import Value } & \multicolumn{4}{|c|}{ Dependent Variable: Export Value } & \multicolumn{4}{|c|}{ Dependent Variable: Import Value } \\
\hline & Model 1 & \begin{tabular}{|l|} 
Model 2 \\
\end{tabular} & \begin{tabular}{|l|} 
Model 3 \\
\end{tabular} & \begin{tabular}{|l|} 
Model 4 \\
\end{tabular} & \begin{tabular}{|l|} 
Model 1 \\
\end{tabular} & Model 2 & \begin{tabular}{|l|} 
Model 3 \\
\end{tabular} & \begin{tabular}{|l|} 
Model 4 \\
\end{tabular} & \begin{tabular}{|l|} 
Model 1 \\
\end{tabular} & \begin{tabular}{|l|} 
Model 2 \\
\end{tabular} & \begin{tabular}{|l|} 
Model 33 \\
\end{tabular} & \begin{tabular}{|l|} 
Model 4 \\
\end{tabular} & Model 1 & \begin{tabular}{|l|} 
Model 2 \\
\end{tabular} & \begin{tabular}{|l|} 
Model 3 \\
\end{tabular} & \begin{tabular}{|l|} 
Model 4 \\
\end{tabular} & Model 1 & \begin{tabular}{|l|} 
Model 2 \\
\end{tabular} & \begin{tabular}{|l|} 
Model 3 \\
\end{tabular} & Model 4 & \begin{tabular}{|l|} 
Model 1 \\
\end{tabular} & \begin{tabular}{|l|} 
Model 2 \\
\end{tabular} & \begin{tabular}{|l|} 
Model 3 \\
\end{tabular} & Model 4 \\
\hline popi & $\begin{array}{l}1.460^{* \star \star} \\
(0.087)\end{array}$ & $\begin{array}{l}1.437^{\star k \star} \\
(0.089)\end{array}$ & $\begin{array}{l}1.398^{\star \star \star} \\
(0.079)\end{array}$ & $\begin{array}{l}1.320^{* \star \star} \\
(0.097)\end{array}$ & $\begin{array}{c}0.980^{\star \star \star} \\
(0.150)\end{array}$ & \begin{tabular}{|c|}
$0.972^{\star \star \star}$ \\
$(0.147)$
\end{tabular} & \begin{tabular}{|c|c|c}
$0.850^{\star \star \star}$ \\
$(0.134)$
\end{tabular} & \begin{tabular}{|c|}
$0.822^{* \star \star}$ \\
$(0.130)$
\end{tabular} & \begin{tabular}{|c|}
$1.301^{\star * \star}$ \\
$(0.082)$
\end{tabular} & \begin{tabular}{c|}
$1.286^{\star \star \star}$ \\
$(0.102)$
\end{tabular} & \begin{tabular}{|c|}
$1.311^{\star \star \star}$ \\
$(0.070)$
\end{tabular} & $\begin{array}{c}1.482^{\star \star \star} \\
(0.075)\end{array}$ & $\begin{array}{l}1.254^{\star \star \star} \\
(0.108)\end{array}$ & $\begin{array}{c}1.191^{\star \star \star} \\
(0.084)\end{array}$ & \begin{tabular}{c|}
$1.087^{\star \star \star *}$ \\
$(0.077)$
\end{tabular} & \begin{tabular}{|c|}
$1.214^{\star \star \star \star}$ \\
$(0.130)$
\end{tabular} & \begin{tabular}{c|}
0.420 \\
$(1.136)$
\end{tabular} & \begin{tabular}{|c}
$1.803^{\star * \star}$ \\
$(0.651)$
\end{tabular} & $\begin{array}{c}2.210^{\star \star \star} \\
(0.431)\end{array}$ & $\begin{array}{l}1.523^{* \star \star} \\
(0.497)\end{array}$ & $\begin{array}{c}-0.654 \\
(0.611)\end{array}$ & $\begin{array}{c}0.548 \\
(0.483)\end{array}$ & $\begin{array}{c}1.844^{\star \star \star} \\
(0.247)\end{array}$ & $\begin{array}{c}1.116^{\star \star \star} \\
(0.357)\end{array}$ \\
\hline popj & $\begin{array}{l}1.279^{\star \star \star} \\
(0.136)\end{array}$ & $\begin{array}{l}1.166^{\star \star *} \\
(0.127)\end{array}$ & $\begin{array}{c}0.869^{\star \star \star} \\
(0.095)\end{array}$ & $\begin{array}{c}0.753^{* \star \star} \\
(0.102)\end{array}$ & \begin{tabular}{|c|c}
$1.368^{\star \star \star}$ \\
$(0.128)$
\end{tabular} & $\begin{array}{c}1.299^{\star \star \star} \\
(0.116)\end{array}$ & \begin{tabular}{|c}
$1.175^{\star \star \star}$ \\
$(0.113)$
\end{tabular} & \begin{tabular}{|c|}
$1.222^{* \star \star}$ \\
$(0.121)$
\end{tabular} & \begin{tabular}{|c|c|}
$0.641^{\star * \star}$ \\
$(0.264)$
\end{tabular} & \begin{tabular}{|c|}
$0.776^{\star \star \star}$ \\
$(0.255)$
\end{tabular} & \begin{tabular}{|c|}
$1.053^{\star \star \star}$ \\
$(0.138)$
\end{tabular} & $\begin{array}{c}1.357^{\star \star \star} \\
(0.119)\end{array}$ & $\begin{array}{l}-0.488 \\
(0.305)\end{array}$ & $\begin{array}{c}0.423^{\star \star \star} \\
(0.175)\end{array}$ & \begin{tabular}{l|}
$1.313^{\star \star \star}$ \\
$(0.124)$
\end{tabular} & \begin{tabular}{|c|}
$1.514^{* * \star}$ \\
$(0.178)$
\end{tabular} & \begin{tabular}{|c|}
$1.162^{\star \star \star}$ \\
$(0.174)$
\end{tabular} & \begin{tabular}{|c|}
$1.357^{\star \star \star}$ \\
$(0.216)$
\end{tabular} & $\begin{array}{c}0.640^{\star * \star} \\
(0.236)\end{array}$ & $\begin{array}{c}0.462^{\star} \\
(0.247)\end{array}$ & $\begin{array}{c}1.251^{\star \star \star} \\
(0.249)\end{array}$ & $\begin{array}{l}1.377^{\star \star \star} \\
(0.262)\end{array}$ & \begin{tabular}{|c|}
$1.218^{\star \star \star}$ \\
$(0.225)$
\end{tabular} & $\begin{array}{c}0.900^{\star \star \star} \\
(0.294)\end{array}$ \\
\hline gdppci & $\begin{array}{c}0.108 \\
(0.473)\end{array}$ & & & & \begin{tabular}{|c}
0.430 \\
$(0.690)$
\end{tabular} & & & & $\begin{array}{c}1.971^{\star \star \star} \\
(0.443)\end{array}$ & & & & $\begin{array}{c}0.296 \\
(0.790)\end{array}$ & & & & \begin{tabular}{c|}
$10.306^{\star \star}$ \\
$(4.623)$
\end{tabular} & & & & $\begin{array}{l}9.725^{\star \star \star} \\
(2.024)\end{array}$ & & & \\
\hline gdppcj & $\begin{array}{l}0.961^{\star \star \star} \\
(0.218)\end{array}$ & & & & $\begin{array}{l}1.124^{*} \\
(0.192)\end{array}$ & & & & $\begin{array}{c}0.758 \\
(0.974)\end{array}$ & & & & $\begin{array}{l}5.666^{* \star \star} \\
(1.340)\end{array}$ & & & & $\begin{array}{c}0.084 \\
(0.206)\end{array}$ & & & & $\begin{array}{c}0.261 \\
(0.482)\end{array}$ & & & \\
\hline gdppci*hkpci & & $\begin{array}{c}1.560^{\star \star \star} \\
(0.196)\end{array}$ & & & & $\begin{array}{c}1.436^{\star \star \star} \\
(0.234)\end{array}$ & & & & $\begin{array}{c}2.061^{\star \star \star} \\
(0.489)\end{array}$ & & & & $\begin{array}{c}-0.055 \\
(0.790)\end{array}$ & & & & $\begin{array}{c}4.751^{\star \star \star} \\
(1.296)\end{array}$ & & & & $\begin{array}{c}4.850^{\star \star \star} \\
(1.017)\end{array}$ & & \\
\hline gdppcj*hkpcj & & $\begin{array}{l}0.946^{\star \star *} \\
(0.203)\end{array}$ & & & & $\begin{array}{l}1.117^{\star \star \star} \\
(0.187)\end{array}$ & & & & $\begin{array}{c}0.026 \\
(0.464)\end{array}$ & & & & $\begin{array}{l}1.094^{\star} \\
(0.619)\end{array}$ & & & & $\begin{array}{c}0.338 \\
(0.236)\end{array}$ & & & & $\begin{array}{c}0.492 \\
(0.446)\end{array}$ & & \\
\hline ecdist & & & $\begin{array}{c}0.099 \\
(0.240)\end{array}$ & & & & $\begin{array}{c}0.443 \\
(0.347)\end{array}$ & & & & \begin{tabular}{|c|}
$0.712^{\star \star \star}$ \\
$(0.122)$
\end{tabular} & & & & $\begin{array}{c}-0.118 \\
(0.213)\end{array}$ & & & & $\begin{array}{c}0.461 \\
(0.293)\end{array}$ & & & & $\begin{array}{c}-0.264 \\
(0.551)\end{array}$ & \\
\hline ecdistthkdist & & & & $\begin{array}{c}1.302^{\star \star \star} \\
(0.142)\end{array}$ & & & & $\begin{array}{c}1.383^{\star \star \star} \\
(0.270)\end{array}$ & & & & \begin{tabular}{|c|}
$0.837^{\star \star \star}$ \\
$(0.177)$
\end{tabular} & & & & $\begin{array}{c}0.115 \\
(0.347) \\
\end{array}$ & & & & \begin{tabular}{|c|}
$2.458^{\star \star \star}$ \\
$(0.678)$
\end{tabular} & & & & $\begin{array}{l}1.115^{\star} \\
(0.549)\end{array}$ \\
\hline hkpci & $\begin{array}{c}-0.073 \\
(0.246)\end{array}$ & & & & \begin{tabular}{|c|}
$2.331^{\star * \star}$ \\
$(0.514)$
\end{tabular} & & & & $\begin{array}{c}-0.009 \\
(0.209)\end{array}$ & & & & $\begin{array}{c}0.429 \\
(0.275)\end{array}$ & & & & $\begin{array}{c}2.316 \\
(1.528)\end{array}$ & & & & $\begin{array}{c}-0.307 \\
(1.369) \\
\end{array}$ & & & \\
\hline hkpcj & $\begin{array}{l}1.530^{\star \star \star} \\
(0.498)\end{array}$ & & & & $\begin{array}{c}-0.181 \\
(0.391) \\
\end{array}$ & & & & $\begin{array}{c}-0.438^{\star \star} \\
(0.195)\end{array}$ & & & & $\begin{array}{c}-2.306^{\star \star \star} \\
(0.348)\end{array}$ & & & & $\begin{array}{c}0.503 \\
(1.157) \\
\end{array}$ & & & & $\begin{array}{l}-0.222 \\
(1.507)\end{array}$ & & & \\
\hline hkdist & & & $\begin{array}{c}-0.044 \\
(0.045) \\
\end{array}$ & & & & $\begin{array}{c}-0.168^{\star \star} \\
(0.073)\end{array}$ & & & & $\begin{array}{c}0.048 \\
(0.036)\end{array}$ & & & & $\begin{array}{l}0.137^{*} \\
(0.079)\end{array}$ & & & & $\begin{array}{l}0.374^{\star *} \\
(0.194)\end{array}$ & & & & $\begin{array}{c}0.029 \\
(0.275) \\
\end{array}$ & \\
\hline distnkpci & & $\begin{array}{c}-2.021^{\star \star \star} \\
(0.274)\end{array}$ & & & & $\begin{array}{c}0.247 \\
(0.356)\end{array}$ & & & & $\begin{array}{c}-1.958^{\star \star \star} \\
(0.569)\end{array}$ & & & & $\begin{array}{c}1.344 \\
(0.839)\end{array}$ & & & & $\begin{array}{c}-1.524 \\
(1.837)\end{array}$ & & & & $\begin{array}{c}-4.458^{\star \star} \\
(2.036)\end{array}$ & & \\
\hline dist*hkpcj & & $\begin{array}{c}0.025 \\
(0.235) \\
\end{array}$ & & & & $\begin{array}{c}-1.667^{\star k \star *} \\
(0.328)\end{array}$ & & & & $\begin{array}{l}-0.265 \\
(0.512) \\
\end{array}$ & & & & $\begin{array}{c}-2.832^{\star \star \star} \\
(0.574)\end{array}$ & & & & $\begin{array}{c}0.924 \\
(1.004)\end{array}$ & & & & $\begin{array}{c}0.145 \\
(1.257)\end{array}$ & & \\
\hline dist*hkdist & & & & $\begin{array}{c}-1.382^{\star \star \star} \\
(0.160)\end{array}$ & & & & $\begin{array}{c}-1.578^{\star \star \star} \\
(0.259)\end{array}$ & & & & $\begin{array}{c}-0.823^{\star \star \star} \\
(0.187)\end{array}$ & & & & $\begin{array}{c}-0.057 \\
(0.361)\end{array}$ & & & & \begin{tabular}{|c}
$-2.269^{\star \star \star}$ \\
$(0.578)$
\end{tabular} & & & & $\begin{array}{c}-1.631^{\star \star \star} \\
(0.629)\end{array}$ \\
\hline dist & $\begin{array}{c}-2.201^{\star \star \star} \\
(0.288)\end{array}$ & & $\begin{array}{c}-2.103^{\star \star \star} \\
(0.251)\end{array}$ & & $\begin{array}{c}-1.742^{\star \star \star} \\
(0.328)\end{array}$ & & $\begin{array}{c}-2.100^{\star \star *} \\
(0.373)\end{array}$ & & $\begin{array}{c}-1.972^{\star \star \star} \\
(0.455)\end{array}$ & & $\begin{array}{c}2.138^{\star * \star} \\
(0.378)\end{array}$ & & $\begin{array}{c}-0.471 \\
(0.561)\end{array}$ & & $\begin{array}{c}-0.797^{\star} \\
(0.424)\end{array}$ & & $\begin{array}{c}-0.783 \\
(0.899) \\
\end{array}$ & & \begin{tabular}{|c|}
$-2.627^{\star \star \star}$ \\
$(0.516)$ \\
\end{tabular} & & $\begin{array}{c}-4.609^{\star \star \star} \\
(1.065)\end{array}$ & & $\begin{array}{c}-4.235^{\star \star \star} \\
(0.630)\end{array}$ & \\
\hline border & $\begin{array}{c}-0.241 \\
(0.384)\end{array}$ & $\begin{array}{c}0.103 \\
(0.466)\end{array}$ & $\begin{array}{c}-0.021 \\
(0.300)\end{array}$ & $\begin{array}{c}1.497^{* \star \star} \\
(0.256)\end{array}$ & $\begin{array}{c}0.132 \\
(0.397)\end{array}$ & $\begin{array}{c}0.703 \\
(0.461)\end{array}$ & $\begin{array}{c}-0.776 \\
(0.525)\end{array}$ & $\begin{array}{c}0.471 \\
(0.388)\end{array}$ & $\begin{array}{c}-0.329 \\
(0.267)\end{array}$ & $\begin{array}{c}-0.415 \\
(0.399) \\
\end{array}$ & $\begin{array}{l}-0.515^{\star} \\
(0.308)\end{array}$ & $\begin{array}{c}-0.224 \\
(0.245)\end{array}$ & $\begin{array}{l}0.689 * \star \\
(0.359)\end{array}$ & $\begin{array}{l}0.601^{*} \\
(0.339)\end{array}$ & $\begin{array}{l}0.760^{\star \star} \\
(0.337)\end{array}$ & \begin{tabular}{|c|}
$0.851^{\star \star \star}$ \\
$(0.346)$
\end{tabular} & $\begin{array}{c}2.295 \\
(1.506)\end{array}$ & $\begin{array}{c}2.070 \\
(1.456)\end{array}$ & $\begin{array}{c}0.471 \\
(0.891)\end{array}$ & $\begin{array}{c}0.703 \\
(0.998)\end{array}$ & $\begin{array}{c}-2.027 \\
(1.576)\end{array}$ & $\begin{array}{c}-2.083 \\
(1.527)\end{array}$ & $\begin{array}{l}-1.855^{\star \star} \\
(0.852)\end{array}$ & $\begin{array}{c}2.065^{\star \star \star} \\
(0.758)\end{array}$ \\
\hline EA & $\begin{array}{l}0.607^{\star k \star} \\
(0.189)\end{array}$ & $\begin{array}{l}0.609^{* \star *} \\
(0.185)\end{array}$ & $\begin{array}{l}0.745^{\star \star \star} \\
(0.180)\end{array}$ & $\begin{array}{l}0.661^{1 \star k} \\
(0.181)\end{array}$ & $\begin{array}{l}0.418^{8 \star \star} \\
(0.139)\end{array}$ & \begin{tabular}{|c|}
$0.433^{\star \star \star}$ \\
$(0.138)$
\end{tabular} & $\begin{array}{l}0.589^{\star \star \star} \\
(0.153)\end{array}$ & $\begin{array}{l}0.571^{\star \star *} \\
(0.148)\end{array}$ & & & & & & & & & $\begin{array}{c}0.293 \\
(0.384)\end{array}$ & $\begin{array}{c}0.405 \\
(0.394) \\
\end{array}$ & \begin{tabular}{|c|}
$1.336^{\star * \star}$ \\
$(0.318)$ \\
\end{tabular} & $\begin{array}{c}1.198^{\star \star \star} \\
(0.326)\end{array}$ & $\begin{array}{c}0.262 \\
(0.272) \\
\end{array}$ & $\begin{array}{c}0.365 \\
(0.276) \\
\end{array}$ & \begin{tabular}{|c|}
$0.622^{\star \star \star}$ \\
$(0.256)$ \\
\end{tabular} & $\begin{array}{c}0.589^{\star \star \star} \\
(0.199) \\
\end{array}$ \\
\hline EURO & & & & & & & & & $\begin{array}{c}-0.035 \\
(0.081)\end{array}$ & $\begin{array}{c}-0.011 \\
(0.080)\end{array}$ & $\begin{array}{c}0.033 \\
(0.094)\end{array}$ & $\begin{array}{c}0.086 \\
(0.104)\end{array}$ & $\begin{array}{c}-0.171 \\
(0.152)\end{array}$ & $\begin{array}{c}0.100 \\
(0.155)\end{array}$ & $\begin{array}{c}0.035 \\
(0.140)\end{array}$ & $\begin{array}{c}0.024 \\
(0.134)\end{array}$ & & & & & & & & \\
\hline constant & $\begin{array}{c}-26.108^{\star \star \star *} \\
(6.599)\end{array}$ & $\begin{array}{c}-36.540^{\star \star \star \star} \\
(3.440)\end{array}$ & \begin{tabular}{c|}
$-9.963^{* \star \star}$ \\
$(3.648)$
\end{tabular} & $\begin{array}{c}-24.162^{\star \star \star} \\
(1.291)\end{array}$ & \begin{tabular}{|c|}
$-18.827^{\star}$ \\
$(10.385)$
\end{tabular} & $\begin{array}{c}-32.871^{\star \star \star} \\
(3.884)\end{array}$ & \begin{tabular}{|c|}
$-9.371^{\star \star \star}$ \\
$(5.874)$
\end{tabular} & $\begin{array}{c}-22.909^{* * *} \\
(3.284)\end{array}$ & $\begin{array}{c}-29.948^{\star \star \star} \\
(8.587)\end{array}$ & $\begin{array}{c}-23.087^{\star \star \star} \\
(4.796)\end{array}$ & $\begin{array}{c}-13.555^{\star \star \star} \\
(4.755)\end{array}$ & $\begin{array}{c}-32.699 * \star \star \\
(2.098)\end{array}$ & \begin{tabular}{|c}
$-55.134^{\star \star \star}$ \\
$(10.559)$
\end{tabular} & $\begin{array}{c}-10.700^{* \star \star} \\
(4.357)\end{array}$ & $\begin{array}{c}-15.915^{\star \star \star} \\
(3.384)\end{array}$ & $\begin{array}{c}-29.518^{\star \star \star} \\
(4.436)\end{array}$ & \begin{tabular}{|c|}
$-97.013^{\star \star \star}$ \\
$(30.474)$
\end{tabular} & \begin{tabular}{|c|}
$-69.217^{\star \star \star}$ \\
$(11.503)$
\end{tabular} & \begin{tabular}{|c|}
$-18.484^{*}$ \\
$(10.659)$
\end{tabular} & $\begin{array}{c}-25.971^{\star \star \star} \\
(8.942)\end{array}$ & \begin{tabular}{|c|}
$-56.747^{\star \star \star}$ \\
$(11.352)$
\end{tabular} & $\begin{array}{c}-32.287^{\star \star \star} \\
(9.865)\end{array}$ & $\begin{array}{c}-2.745 \\
(7.006)\end{array}$ & $\begin{array}{c}-20.558^{\star \star \star} \\
(7.590)\end{array}$ \\
\hline No obs & 886 & 886 & 886 & 886 & 892 & 892 & 892 & 892 & 320 & 320 & 320 & 320 & 321 & 321 & 321 & 321 & 219 & 219 & 219 & 219 & 208 & 208 & 208 & 208 \\
\hline & 0.9633 & \begin{tabular}{|l|l|}
0.9679 \\
\end{tabular} & $\begin{array}{ll}0.9647 \\
\end{array}$ & 0.9612 & 0.953 & 0.953 & 0.949 & 0.951 & 0.993 & 0.991 & \begin{tabular}{|l|}
0.993 \\
\end{tabular} & 0.991 & 0.981 & \begin{tabular}{|l|l}
0.983 \\
\end{tabular} & 0.983 & 0.973 & 0.917 & 0.9155 & 0.9131 & 0.909 & 0.919 & 0.928 & 0.929 & 0.927 \\
\hline Wald Chi2 & $11232.23 * \star$ & $6363.32^{2 \star *}$ & $7086.41^{\star \star \star}$ & $6367.47^{\star \star *}$ & $804.890^{\star *}$ & $721.61^{\star \star \star *}$ & $425^{\star \star \star}$ & $763.62^{\star \star \star}$ & $3531.86^{* \star \star}$ & $2452.70^{\star \star \star *}$ & $2501.03^{* \star *}$ & $2745.62^{2 * \star}$ & $1643.24 * x$ & $2958.70^{\star * \star *}$ & $2307.57^{7 * *}$ & $1322.56^{\star \star \star}$ & $866.91^{\star \star *}$ & $753.65^{\star \star \star}$ & $579.67^{\star \star \star}$ & $392.18^{\star \star \star}$ & $3596.23^{* \star *}$ & $1820.82^{2 * \star x}$ & $1386.570^{*}$ & 653.91**夫 \\
\hline
\end{tabular}




\begin{tabular}{|c|c|c|c|c|c|c|c|c|c|c|c|c|c|c|c|c|c|c|c|c|c|c|c|c|}
\hline \multirow{3}{*}{$\begin{array}{l}\text { Textiles \& } \\
\text { clothing }\end{array}$} & \multicolumn{8}{|c|}{ North-East } & \multicolumn{8}{|c|}{ North-South } & \multicolumn{8}{|c|}{ South-East } \\
\hline & \multicolumn{4}{|c|}{ Dependent Variable: Export Value } & \multicolumn{4}{|c|}{ Dependent Variable: Import Value } & \multicolumn{4}{|c|}{\begin{tabular}{l|l} 
Dependent Variable: Export Value \\
\end{tabular}} & \multicolumn{4}{|c|}{ Dependent Variable: Import Value } & \multicolumn{4}{|c|}{ Dependent Variable: Export Value } & \multicolumn{4}{|c|}{ Dependent Variable: Import Value } \\
\hline & Model 1 & Model 2 & Model 3 & Model 4 & Model 1 & Model 2 & Model 3 & Model 4 & Model 1 & Model 2 & \begin{tabular}{|l|} 
Model 3 \\
\end{tabular} & Model 4 & Model 1 & \begin{tabular}{|l|} 
Model 2 \\
\end{tabular} & Model 3 & Model 4 & Model 1 & Model 2 & Model 3 & Model 4 & Model 1 & Model 2 & Model 3 & Model 4 \\
\hline popi & $\begin{array}{c}1.488^{\star \star \star} \\
(0.067)\end{array}$ & $\begin{array}{c}1.449^{\star \star \star} \\
(0.067)\end{array}$ & $\begin{array}{c}1.530^{\star \star \star} \\
(0.085)\end{array}$ & $\begin{array}{c}1.544^{\star \star \star} \\
(0.086)\end{array}$ & $\begin{array}{c}1.152^{\star \star \star} \\
(0.087)\end{array}$ & $\begin{array}{c}1.142^{\star \star \star} \\
(0.098)\end{array}$ & $\begin{array}{c}1.151^{\star \star \star} \\
(0.099)\end{array}$ & $\begin{array}{c}1.153^{\star \star \star} \\
(0.101)\end{array}$ & $\begin{array}{c}1.144^{\star \star \star} \\
(0.045)\end{array}$ & $\begin{array}{c}1.163^{\star \star \star} \\
(0.041)\end{array}$ & $\begin{array}{c}1.207^{\star \star \star} \\
(0.047)\end{array}$ & $\begin{array}{c}1.406^{\star \star \star} \\
(0.052)\end{array}$ & $\begin{array}{c}0.889^{\star \star \star} \\
(0.050)\end{array}$ & $\begin{array}{c}0.887^{\star \star \star} \\
(0.028)\end{array}$ & $\begin{array}{c}0.797^{\star \star \star} \\
(0.083)\end{array}$ & \begin{tabular}{|c|}
$0.794^{\star \star \star}$ \\
$(0.083)$
\end{tabular} & $\begin{array}{c}-1.620^{\star \star \star} \\
(0.642)\end{array}$ & $\begin{array}{c}0.122 \\
(0.252)\end{array}$ & $\begin{array}{c}0.981^{\star \star \star} \\
(0.279)\end{array}$ & $\begin{array}{l}0.487^{\star} \\
(0.268)\end{array}$ & $\begin{array}{l}-0.200 \\
(0.855)\end{array}$ & \begin{tabular}{c|}
$1.573^{\star \star \star}$ \\
$(0.373)$
\end{tabular} & $\begin{array}{c}1.991^{\star \star \star} \\
(0.203)\end{array}$ & $\begin{array}{c}1.372^{\star \star \star} \\
(0.198)\end{array}$ \\
\hline popj & $\begin{array}{c}1.170^{* \star *} \\
(0.171)\end{array}$ & $\begin{array}{c}1.062^{\star \star \star} \\
(0.159)\end{array}$ & $\begin{array}{c}0.792^{\star \star \star} \\
(0.120)\end{array}$ & $\begin{array}{c}0.857^{\star \star \star} \\
(0.126)\end{array}$ & $\begin{array}{c}1.059^{* \star \star} \\
(0.149)\end{array}$ & $\begin{array}{c}1.028^{\star \star \star} \\
(0.128)\end{array}$ & $\begin{array}{c}0.974^{* \star \star} \\
(0.127)\end{array}$ & $\begin{array}{c}0.974^{\star \star \star} \\
(0.126)\end{array}$ & $\begin{array}{l}-0.494 \\
(0.317)\end{array}$ & $\begin{array}{l}-0.130 \\
(0.195)\end{array}$ & $\begin{array}{l}0.264^{\star} \\
(0.140)\end{array}$ & $\begin{array}{c}0.690^{* \star *} \\
(0.101)\end{array}$ & $\begin{array}{c}-1.240^{* \star \star} \\
(0.245)\end{array}$ & \begin{tabular}{|c|}
$-0.775^{* \star \star}$ \\
$(0.147)$ \\
\end{tabular} & $\begin{array}{c}-0.791^{\star \star \star} \\
(0.161)\end{array}$ & \begin{tabular}{|c|}
$-0.818^{\star \star *}$ \\
$(0.147)$ \\
\end{tabular} & \begin{tabular}{|c}
$1.482^{\star \star \star}$ \\
$(0.166)$
\end{tabular} & $\begin{array}{l}1.694^{\star \star \star} \\
(0.155)\end{array}$ & \begin{tabular}{|c}
$1.079^{\star \star \star}$ \\
$(0.176)$
\end{tabular} & $\begin{array}{c}0.884^{\star \star \star} \\
(0.229)\end{array}$ & \begin{tabular}{|c|}
$0.750^{\star \star \star}$ \\
$(0.222)$ \\
\end{tabular} & $\begin{array}{c}1.019^{* \star *} \\
(0.148)\end{array}$ & \begin{tabular}{|c|}
$0.945^{\star * \star}$ \\
$(0.089)$ \\
\end{tabular} & $\begin{array}{c}0.801^{* \star \star} \\
(0.112)\end{array}$ \\
\hline gdppci & $\begin{array}{c}2.511^{\star \star \star} \\
(0.427)\end{array}$ & & & & $\begin{array}{c}2.528^{\star \star \star \star} \\
(0.433)\end{array}$ & & & & $\begin{array}{c}1.436^{\star \star \star} \\
(0.363)\end{array}$ & & & & $\begin{array}{c}1.772^{\star \star \star} \\
(0.287)\end{array}$ & & & & $\begin{array}{c}10.921^{\star \star \star} \\
(2.761)\end{array}$ & & & & \begin{tabular}{|c}
$8.435^{\star \star \star}$ \\
$(3.258)$
\end{tabular} & & & \\
\hline gdppcj & $\begin{array}{c}0.313 \\
(0.212)\end{array}$ & & & & $\begin{array}{c}0.129 \\
(0.193)\end{array}$ & & & & $\begin{array}{l}2.029^{*} \\
(1.118)\end{array}$ & & & & $\begin{array}{c}1.027 \\
(0.931)\end{array}$ & & & & $\begin{array}{c}1.000^{\star \star \star} \\
(0.208)\end{array}$ & & & & $\begin{array}{l}0.636^{*} \\
(0.351)\end{array}$ & & & \\
\hline gdppci*hkpci & & $\begin{array}{c}3.391^{\star \star \star} \\
(0.281)\end{array}$ & & & & \begin{tabular}{|c}
$2.732^{\star \star \star}$ \\
$(0.178)$
\end{tabular} & & & & $\begin{array}{c}1.348^{\star \star \star} \\
(0.347)\end{array}$ & & & & \begin{tabular}{|c|}
$1.817^{\star \star \star}$ \\
$(0.202)$
\end{tabular} & & & & $\begin{array}{c}3.299^{\star \star \star} \\
(0.739)\end{array}$ & & & & $\begin{array}{c}1.083 \\
(0.988) \\
\end{array}$ & & \\
\hline $\mid$ gdppcj*hkpcj| & & $\begin{array}{c}0.255 \\
(0.210)\end{array}$ & & & & $\begin{array}{c}0.131 \\
(0.185)\end{array}$ & & & & $\begin{array}{c}0.539 \\
(0.500)\end{array}$ & & & & $\begin{array}{c}-1.060^{\star * *} \\
(0.373)\end{array}$ & & & & $\begin{array}{l}1.115^{\star \star \star} \\
(0.220)\end{array}$ & & & & $\begin{array}{l}0.914^{\star \star \star} \\
(0.288)\end{array}$ & & \\
\hline ecdist & & & $\begin{array}{c}2.271^{\star \star \star} \\
(0.399)\end{array}$ & & & & $\begin{array}{c}2.135^{\star \star \star} \\
(0.368)\end{array}$ & & & & $\begin{array}{c}0.369^{\star \star \star} \\
(0.105)\end{array}$ & & & & \begin{tabular}{|c|}
$0.469^{\star \star \star}$ \\
$(0.091)$
\end{tabular} & & & & $\begin{array}{c}-0.795^{*} \\
(0.417) \\
\end{array}$ & & & & \begin{tabular}{|c}
$-1.073^{* \star *}$ \\
$(0.264)$
\end{tabular} & \\
\hline ecdistthkdist & & & & $\begin{array}{c}2.230^{\star \star \star} \\
(0.194)\end{array}$ & & & & $\begin{array}{c}1.677^{\star \star \star} \\
(0.125)\end{array}$ & & & & $\begin{array}{c}0.547^{\star \star \star} \\
(0.124)\end{array}$ & & & & $\begin{array}{c}0.473^{\star \star \star} \\
(0.086)\end{array}$ & & & & $\begin{array}{c}0.197 \\
(0.454)\end{array}$ & & & & $\begin{array}{l}0.723^{\star *} \\
(0.329)\end{array}$ \\
\hline hkpci & $\begin{array}{c}1.227^{\star \star \star} \\
(0.341)\end{array}$ & & & & $\begin{array}{c}1.309^{\star \star \star} \\
(0.303)\end{array}$ & & & & $\begin{array}{c}-0.186 \\
(0.191)\end{array}$ & & & & $\begin{array}{c}0.122 \\
(0.171)\end{array}$ & & & & $\begin{array}{c}0.497 \\
(0.803)\end{array}$ & & & & $\begin{array}{c}-0.489 \\
(0.780)\end{array}$ & & & \\
\hline hkpcj & $\begin{array}{l}1.402^{\star \star \star} \\
(0.418)\end{array}$ & & & & $\begin{array}{l}0.567^{\star *} \\
(0.292)\end{array}$ & & & & $\begin{array}{c}-1.005^{\star * \star} \\
(0.232)\end{array}$ & & & & \begin{tabular}{|c|}
$-1.099 * \star$ \\
$(0.199)$
\end{tabular} & & & & $\begin{array}{l}1.425^{\star \star} \\
(0.607)\end{array}$ & & & & $\begin{array}{c}1.056 \\
(1.123) \\
\end{array}$ & & & \\
\hline hkdist & & & $\begin{array}{l}-0.034 \\
(0.053) \\
\end{array}$ & & & & $\begin{array}{l}-0.047 \\
(0.055) \\
\end{array}$ & & & & $\begin{array}{c}-0.014 \\
(0.033) \\
\end{array}$ & & & & $\begin{array}{c}0.012 \\
(0.028) \\
\end{array}$ & & & & $\begin{array}{l}0.216^{\star \star} \\
(0.108)\end{array}$ & & & & $\begin{array}{c}0.086 \\
(0.123) \\
\end{array}$ & \\
\hline dist*hkpci & & $\begin{array}{c}-2.494^{\star \star \star} \\
(0.263) \\
\end{array}$ & & & & $\begin{array}{c}-1.506^{\star \star \star} \\
(0.256) \\
\end{array}$ & & & & $\begin{array}{c}-1.304^{\star \star \star} \\
(0.438) \\
\end{array}$ & & & & $\begin{array}{c}-1.522^{\star \star \star} \\
(0.310) \\
\end{array}$ & & & & $\begin{array}{c}-1.882^{* \star} \\
(0.946)\end{array}$ & & & & $\begin{array}{c}-0.671 \\
(1.241) \\
\end{array}$ & & \\
\hline dist*hkpcj & & $\begin{array}{l}0.629^{* \star} \\
(0.283)\end{array}$ & & & & $\begin{array}{c}0.285 \\
(0.231) \\
\end{array}$ & & & & $\begin{array}{c}-1.317^{\star \star \star} \\
(0.527) \\
\end{array}$ & & & & $\begin{array}{c}0.398 \\
(0.389) \\
\end{array}$ & & & & $\begin{array}{l}1.408^{\star \star} \\
(0.625)\end{array}$ & & & & $\begin{array}{c}-0.676 \\
(0.876) \\
\end{array}$ & & \\
\hline dist*hkdist & & & & \begin{tabular}{c|c}
$-2.261^{\star \star *}$ \\
$(0.226)$
\end{tabular} & & & & $\begin{array}{c}-1.703^{\star \star *} \\
(0.137)\end{array}$ & & & & \begin{tabular}{|c|}
$-0.588^{\star \star \star}$ \\
$(0.127)$ \\
\end{tabular} & & & & \begin{tabular}{|c}
$-0.460^{\star \star *}$ \\
$(0.098)$
\end{tabular} & & & & $\begin{array}{l}-0.263 \\
(0.433) \\
\end{array}$ & & & & \begin{tabular}{|c}
$-0.840^{\star \star \star}$ \\
$(0.328)$
\end{tabular} \\
\hline dist & $\begin{array}{c}-2.159^{\star \star \star} \\
(0.360)\end{array}$ & & $\begin{array}{c}-2.223^{\star \star \star} \\
(0.342)\end{array}$ & & $\begin{array}{c}-1.295^{* *} \\
(0.318)\end{array}$ & & $\begin{array}{c}-1.501^{\star \star \star} \\
(0.269)\end{array}$ & & \begin{tabular}{|c|}
$-2.520^{\star * \star}$ \\
$(0.258)$ \\
\end{tabular} & & \begin{tabular}{|c|}
$-2.432^{\star \star \star}$ \\
$(0.233)$ \\
\end{tabular} & & \begin{tabular}{|c|}
$-0.644^{\star \star \star}$ \\
$(0.123)$
\end{tabular} & & $\begin{array}{l}-0.339 \\
(0.302)\end{array}$ & & $\begin{array}{c}-0.569 \\
(0.465)\end{array}$ & & $\begin{array}{c}-0.962^{* *} \\
(0.472)\end{array}$ & & \begin{tabular}{|c|}
$-1.666^{\star \star \star}$ \\
$(0.463)$
\end{tabular} & & $\begin{array}{c}-1.554^{\star * \star} \\
(0.446)\end{array}$ & \\
\hline border & $\begin{array}{l}-0.393 \\
(0.679) \\
\end{array}$ & $\begin{array}{c}0.276 \\
(0.564) \\
\end{array}$ & $\begin{array}{l}-0.626 \\
(0.539) \\
\end{array}$ & $\begin{array}{l}-0.635^{*} \\
(0.372) \\
\end{array}$ & $\begin{array}{c}0.851 \\
(0.555) \\
\end{array}$ & $\begin{array}{l}0.952^{\star *} \\
(0.465)\end{array}$ & $\begin{array}{c}0.248 \\
(0.448) \\
\end{array}$ & $\begin{array}{l}-0.118 \\
(0.270) \\
\end{array}$ & $\begin{array}{c}-0.628^{* \star \star} \\
(0.134) \\
\end{array}$ & $\begin{array}{c}-0.629 \star \star \star \\
(0.136) \\
\end{array}$ & \begin{tabular}{|c|}
$-0.609^{* \star \star}$ \\
$(0.114)$ \\
\end{tabular} & $\begin{array}{l}-0.189 \\
(0.172) \\
\end{array}$ & \begin{tabular}{|c}
$0.963^{* \star \star}$ \\
$(0.134)$ \\
\end{tabular} & \begin{tabular}{|c|}
$0.769 \star \star *$ \\
$(0.162)$ \\
\end{tabular} & $\begin{array}{c}1.233^{* \star \star} \\
(0.178)\end{array}$ & \begin{tabular}{|c|}
$1.181^{\star \star \star}$ \\
$(0.154)$ \\
\end{tabular} & $\begin{array}{c}3.105^{\star \star \star} \\
(0.675) \\
\end{array}$ & $\begin{array}{c}2.380^{\star \star \star} \\
(0.663)\end{array}$ & $\begin{array}{c}3.020^{\star \star \star} \\
(0.708)\end{array}$ & $\begin{array}{c}3.895^{\star * *} \\
(0.689)\end{array}$ & $\begin{array}{l}2.447^{\star \star} \\
(1.105) \\
\end{array}$ & $\begin{array}{l}2.208^{\star} \\
(0.965)\end{array}$ & $\begin{array}{c}1.890^{\star \star \star} \\
(0.771)\end{array}$ & \begin{tabular}{|c}
$2.645^{\star \star \star}$ \\
$(0.716)$
\end{tabular} \\
\hline EA & $\begin{array}{c}0.451^{\star \star \star} \\
(0.158)\end{array}$ & $\begin{array}{c}0.433^{\star \star \star} \\
(0.151)\end{array}$ & $\begin{array}{c}0.589^{\star \star \star} \\
(0.172)\end{array}$ & $\begin{array}{c}0.590^{* \star \star} \\
(0.172)\end{array}$ & $\begin{array}{c}0.511^{\star \star \star} \\
(0.177)\end{array}$ & $\begin{array}{c}0.507 * \star \\
(0.175)\end{array}$ & $\begin{array}{c}0.671^{\star \star \star} \\
(0.192)\end{array}$ & $\begin{array}{l}0.695^{\star \star \star} \\
(0.195)\end{array}$ & & & & & & & & & $\begin{array}{l}0.516^{\star \star} \\
(0.229)\end{array}$ & $\begin{array}{l}0.696^{\star \star \star} \\
(0.256)\end{array}$ & $\begin{array}{c}1.314^{\star \star \star} \\
(0.309) \\
\end{array}$ & $\begin{array}{c}1.114^{* \star \star} \\
(0.312)\end{array}$ & \begin{tabular}{|c|}
$0.557^{\star \star \star}$ \\
$(0.212)$ \\
\end{tabular} & $\begin{array}{c}0.732^{* \star *} \\
(0.232)\end{array}$ & $\begin{array}{c}0.986^{* \star \star} \\
(0.198) \\
\end{array}$ & \begin{tabular}{|c|}
$0.774^{* \star \star}$ \\
$(0.215)$ \\
\end{tabular} \\
\hline EURO & & & & & & & & & $\begin{array}{l}-0.029 \\
(0.107) \\
\end{array}$ & $\begin{array}{c}0.047 \\
(0.103) \\
\end{array}$ & $\begin{array}{c}0.078 \\
(0.107) \\
\end{array}$ & $\begin{array}{c}0.066 \\
(0.102)\end{array}$ & $\begin{array}{c}0.037 \\
(0.100) \\
\end{array}$ & $\begin{array}{c}0.118 \\
(0.089)\end{array}$ & $\begin{array}{c}0.081 \\
(0.073)\end{array}$ & \begin{tabular}{|c|}
0.080 \\
$(0.073)$
\end{tabular} & & & & & & & & \\
\hline constant & $\begin{array}{c}-33.310^{\star \star \star \star} \\
(8.136)\end{array}$ & $\begin{array}{c}-43.873^{\star \star \star} \\
(4.683)\end{array}$ & $\begin{array}{c}-29.979 \star \star \star \\
(6.483)\end{array}$ & $\begin{array}{c}-30.533^{\star \star \star} \\
(2.378) \\
\end{array}$ & \begin{tabular}{|c|}
$-32.185^{\star \star \star}$ \\
$(7.826)$
\end{tabular} & $\begin{array}{c}-34.795^{\star \star \star} \\
(4.020)\end{array}$ & \begin{tabular}{|c|}
$-29.667^{\star * \star}$ \\
$(5.916)$
\end{tabular} & $\begin{array}{c}-23.600^{\star \star \star \star} \\
(1.916)\end{array}$ & $\begin{array}{r}-11.370 \\
(7.814) \\
\end{array}$ & $\begin{array}{c}-0.694 \\
(4.217) \\
\end{array}$ & $\begin{array}{l}8.112^{\star} \\
(4.895)\end{array}$ & $\begin{array}{c}-17.904 * \star \star \\
(2.046)\end{array}$ & $\begin{array}{l}-1.792 \\
(5.742)\end{array}$ & \begin{tabular}{|c|}
$15.232^{\star \star \star}$ \\
$(2.417)$ \\
\end{tabular} & $\begin{array}{c}16.465^{\star \star *} \\
(4.734)\end{array}$ & $\begin{array}{c}17.840^{\star \star \star \star} \\
(3.017)\end{array}$ & \begin{tabular}{|c|}
$-84.446^{\star \star \star \star}$ \\
$(16.203)$ \\
\end{tabular} & $\begin{array}{c}-40.602^{\star \star \star} \\
(3.382)\end{array}$ & $\begin{array}{l}-5.450 \\
(5.858) \\
\end{array}$ & $\begin{array}{l}-9.561 \\
(5.917) \\
\end{array}$ & $\begin{array}{c}-71.519^{\star \star \star} \\
(17.506) \\
\end{array}$ & $\begin{array}{c}-34.200^{\star \star \star} \\
(5.473) \\
\end{array}$ & $\begin{array}{c}-13.073^{\star \star \star} \\
(4.834)\end{array}$ & $\begin{array}{c}-23.091^{\star \star \star} \\
(3.638)\end{array}$ \\
\hline No obs & 908 & 908 & 908 & 908 & 918 & 918 & \begin{tabular}{|l|}
918 \\
\end{tabular} & \begin{tabular}{|l|}
918 \\
\end{tabular} & 320 & 320 & 320 & \begin{tabular}{|l|}
320 \\
\end{tabular} & 321 & \begin{tabular}{|l|}
321 \\
\end{tabular} & 321 & 321 & 243 & 243 & 243 & 243 & \begin{tabular}{|l|}
241 \\
\end{tabular} & \begin{tabular}{|l|}
241 \\
\end{tabular} & 241 & 241 \\
\hline $\begin{array}{ll}R 2 \\
\end{array}$ & 0.979 & 0.9803 & 0.9742 & 0.9746 & 0.983 & 0.984 & 0.982 & \begin{tabular}{|c|}
0.982 \\
\end{tabular} & 0.997 & $\begin{array}{l}0.996 \\
\end{array}$ & 0.996 & \begin{tabular}{|l|}
0.996 \\
\end{tabular} & 0.996 & \begin{tabular}{|l|}
0.997 \\
\end{tabular} & 0.995 & 0.995 & 0.9572 & 0.9622 & 0.9404 & $\begin{array}{ll}0.9388 \\
\end{array}$ & \begin{tabular}{|l|}
0.924 \\
\end{tabular} & 0.932 & 0.933 & 0.914 \\
\hline Wald Chi2 & $1875.05^{\star \star \star}$ & $2751.8^{\star \star \star}$ & $1996.69^{* \star \star}$ & $1757.5^{\star \star \star}$ & $6278.73^{\star \star \star}$ & $6989.47^{* \star *}$ & $4537.59^{* \star * *}$ & $4159.58^{\star \star \star *}$ & $7204.71^{* * *}$ & $5314.88^{\star \star \star *}$ & $3388.27 * * *$ & $2354.34^{* \star *}$ & $2103.65 * \star *$ & $2468.43^{* * *}$ & $1458.24^{* \star *}$ & $1290.87^{\star \star \star}$ & $3001.74^{* \star *}$ & $2691.93^{* \star *}$ & $2012.53^{\star \star \star x}$ & $1222.11^{\star \star \star}$ & $718.57^{\star \star \star}$ & $632.33^{\star \star \star *}$ & $819.38^{* \star *}$ & $718.27^{\star \star \star}$ \\
\hline
\end{tabular}




\begin{tabular}{|c|c|c|c|c|c|c|c|c|c|c|c|c|c|c|c|c|c|c|c|c|c|c|c|c|}
\hline \multirow{3}{*}{$\begin{array}{c}\text { Transport } \\
\text { Equipment }\end{array}$} & \multicolumn{8}{|c|}{ North-East } & \multicolumn{8}{|c|}{ North-South } & \multicolumn{8}{|c|}{ South-East } \\
\hline & \multicolumn{4}{|c|}{ Dependent Variable: Export Value } & \multicolumn{4}{|c|}{ Dependent Variable: Import Value } & \multicolumn{4}{|c|}{ Dependent Variable: Export Value } & \multicolumn{4}{|c|}{ Dependent Variable: Import Value } & \multicolumn{4}{|c|}{ Dependent Variable: Export Value } & \multicolumn{4}{|c|}{\begin{tabular}{|l|} 
Dependent Variable: Import Value \\
\end{tabular}} \\
\hline & Model 1 & \begin{tabular}{|l|} 
Model 2 \\
\end{tabular} & \begin{tabular}{|l|} 
Model 3 \\
\end{tabular} & Model 4 & Model 1 & Model 2 & \begin{tabular}{|l|l|} 
Model 3 \\
\end{tabular} & Model 4 & \begin{tabular}{l|l} 
Model 1 \\
\end{tabular} & \begin{tabular}{|l|} 
Model 2 \\
\end{tabular} & \begin{tabular}{|l|} 
Model 3 \\
\end{tabular} & Model 4 & Model 1 & \begin{tabular}{|l|} 
Model 2 \\
\end{tabular} & \begin{tabular}{|l|} 
Model 3 \\
\end{tabular} & Model 4 & \begin{tabular}{|l|} 
Model 1 \\
\end{tabular} & \begin{tabular}{|l|} 
Model 2 \\
\end{tabular} & \begin{tabular}{|l|} 
Model 3 \\
\end{tabular} & Model 4 & \begin{tabular}{|l|} 
Model 1 \\
\end{tabular} & Model 2 & \begin{tabular}{|l|} 
Model 3 \\
\end{tabular} & Model 4 \\
\hline popi & $\begin{array}{c}1.584^{\star \star \star} \\
(0.058)\end{array}$ & $\begin{array}{c}1.575^{\star \star \star} \\
(0.062)\end{array}$ & $\begin{array}{c}1.505^{\star \star \star} \\
(0.072)\end{array}$ & $\begin{array}{c}1.507^{\star \star \star} \\
(0.073)\end{array}$ & $\begin{array}{c}1.362^{\star \star \star} \\
(0.099)\end{array}$ & $\begin{array}{c}1.350^{\star \star \star} \\
(0.099)\end{array}$ & $\begin{array}{c}1.358^{\star \star \star} \\
(0.106)\end{array}$ & $\begin{array}{c}1.280^{\star \star \star} \\
(0.117)\end{array}$ & $\begin{array}{c}1.667^{\star \star \star} \\
(0.074)\end{array}$ & $\begin{array}{l}1.675^{\star \star \star} \\
(0.070)\end{array}$ & $\begin{array}{c}1.693^{\star \star \star} \\
(0.056)\end{array}$ & $\begin{array}{c}1.796^{\star * \star} \\
(0.076)\end{array}$ & $\begin{array}{c}1.541^{\star \star \star} \\
(0.088)\end{array}$ & $\begin{array}{c}1.421^{\star \star *} \\
(0.106)\end{array}$ & $\begin{array}{c}1.565^{\star \star \star} \\
(0.163)\end{array}$ & $\begin{array}{c}1.659^{* \star \star} \\
(0.161)\end{array}$ & $\begin{array}{c}0.277 \\
(0.904)\end{array}$ & $\begin{array}{c}2.829^{\star \star \star} \\
(0.243)\end{array}$ & $\begin{array}{c}3.636^{\star \star \star} \\
(0.308)\end{array}$ & $\begin{array}{c}3.128^{\star \star \star} \\
(0.442)\end{array}$ & $\begin{array}{c}0.444 \\
(0.826) \\
\end{array}$ & $\begin{array}{c}1.361^{\star \star \star} \\
(0.466)\end{array}$ & $\begin{array}{c}1.589^{\star \star \star} \\
(0.545)\end{array}$ & $\begin{array}{c}0.537 \\
(0.570) \\
\end{array}$ \\
\hline popj & $\begin{array}{c}1.094^{\star \star \star} \\
(0.135)\end{array}$ & $\begin{array}{l}1.011^{\star \star \star} \\
(0.137)\end{array}$ & $\begin{array}{c}0.589^{* \star \star} \\
(0.135)\end{array}$ & \begin{tabular}{|c|}
$0.594^{* * \star}$ \\
$(0.144)$
\end{tabular} & $\begin{array}{l}1.547^{\star \star \star} \\
(0.120)\end{array}$ & $\begin{array}{c}1.601^{* \star *} \\
(0.125)\end{array}$ & $\begin{array}{c}1.316^{* \star *} \\
(0.100)\end{array}$ & $\begin{array}{c}1.263^{\star \star \star} \\
(0.122)\end{array}$ & $\begin{array}{c}-0.053 \\
(0.411) \\
\end{array}$ & $\begin{array}{l}0.508^{*} \\
(0.277)\end{array}$ & $\begin{array}{l}1.025^{\star \star \star} \\
(0.197)\end{array}$ & $\begin{array}{c}1.206^{\star \star *} \\
(0.181)\end{array}$ & $\begin{array}{l}-0.841 \\
(0.755)\end{array}$ & \begin{tabular}{|c}
$2.372^{\star \star *}$ \\
$(0.343)$
\end{tabular} & $\begin{array}{c}3.726^{\star \star \star} \\
(0.262)\end{array}$ & \begin{tabular}{|c|}
$3.641^{* * \star}$ \\
$(0.216)$
\end{tabular} & $\begin{array}{c}1.037 * \star \star \\
(0.226) \\
\end{array}$ & $\begin{array}{l}1.377^{\star \star \star} \\
(0.227)\end{array}$ & \begin{tabular}{|c|}
$0.703^{\star \star \star}$ \\
$(0.213)$
\end{tabular} & $\begin{array}{l}0.478^{*} \\
(0.275)\end{array}$ & \begin{tabular}{|c|}
$1.284^{\star \star \star}$ \\
$(0.291)$
\end{tabular} & $\begin{array}{c}1.357 * \star \star \\
(0.268)\end{array}$ & $\begin{array}{l}1.295^{\star \star \star} \\
(0.204)\end{array}$ & $\begin{array}{c}1.030^{* * \star} \\
(0.207) \\
\end{array}$ \\
\hline gdppci & $\begin{array}{c}2.905^{\star \star \star} \\
(0.429)\end{array}$ & & & & $\begin{array}{c}2.358^{\star \star \star} \\
(0.543)\end{array}$ & & & & $\begin{array}{l}0.760^{\star *} \\
(0.332)\end{array}$ & & & & $\begin{array}{c}2.981^{\star \star \star} \\
(0.762)\end{array}$ & & & & $\begin{array}{c}12.217^{\star \star \star} \\
(3.885)\end{array}$ & & & & \begin{tabular}{|c|}
3.254 \\
$(3.393)$
\end{tabular} & & & \\
\hline gdppcj & $\begin{array}{l}0.712^{\star \star \star} \\
(0.160)\end{array}$ & & & & $\begin{array}{l}2.179 * \star \star \\
(0.229)\end{array}$ & & & & $\begin{array}{l}3.680^{\star *} \\
(1.557)\end{array}$ & & & & $\begin{array}{c}15.082^{\star \star \star} \\
(2.857)\end{array}$ & & & & $\begin{array}{c}1.294^{\star \star \star} \\
(0.329)\end{array}$ & & & & $\begin{array}{c}2.340 \star \star \star \\
(0.333)\end{array}$ & & & \\
\hline gdppci*hkpci & & $\begin{array}{l}3.485^{\star \star \star} \\
(0.277)\end{array}$ & & & & $\begin{array}{c}1.880^{\star \star \star} \\
(0.348)\end{array}$ & & & & $\begin{array}{c}0.788^{\star \star \star} \\
(0.325)\end{array}$ & & & & $\begin{array}{l}1.798^{\star \star} \\
(0.830)\end{array}$ & & & & $\begin{array}{c}3.185^{\star \star \star} \\
(1.018)\end{array}$ & & & & $\begin{array}{c}-0.597 \\
(1.022)\end{array}$ & & \\
\hline gdppcj*hkpcj & & $\begin{array}{c}0.722^{\star \star \star} \\
(0.158)\end{array}$ & & & & $\begin{array}{c}2.176^{\star \star \star} \\
(0.239)\end{array}$ & & & & $\begin{array}{l}1.220^{*} \\
(0.644)\end{array}$ & & & & $\begin{array}{c}0.711 \\
(1.189)\end{array}$ & & & & $\begin{array}{c}1.706^{\star \star \star} \\
(0.318)\end{array}$ & & & & $\begin{array}{c}2.434^{\star \star \star} \\
(0.320)\end{array}$ & & \\
\hline ecdist & & & $\begin{array}{c}2.605^{\star \star *} \\
(0.454)\end{array}$ & & & & $\begin{array}{c}0.407 \\
(0.349)\end{array}$ & & & & \begin{tabular}{|c|}
$0.344^{\star \star \star}$ \\
$(0.130)$
\end{tabular} & & & & $\begin{array}{l}0.902^{\star *} \\
(0.387)\end{array}$ & & & & $\begin{array}{c}-1.447^{\star \star \star} \\
(0.546)\end{array}$ & & & & $\begin{array}{c}-1.867^{\star \star \star} \\
(0.386)\end{array}$ & \\
\hline ecdistthkdist & & & & $\begin{array}{c}2.552^{\star \star \star} \\
(0.152)\end{array}$ & & & & $\begin{array}{c}1.801^{\star \star \star} \\
(0.183)\end{array}$ & & & & $\begin{array}{l}0.451^{\star \star \star} \\
(0.107)\end{array}$ & & & & $\begin{array}{l}0.946^{\star \star} \\
(0.395)\end{array}$ & & & & $\begin{array}{c}-1.267^{\star \star *} \\
(0.502)\end{array}$ & & & & $\begin{array}{c}-0.219 \\
(0.283)\end{array}$ \\
\hline hkpci & $\begin{array}{c}0.816^{\star \star \star} \\
(0.295)\end{array}$ & & & & $\begin{array}{c}1.240^{\star \star \star} \\
(0.294)\end{array}$ & & & & $\begin{array}{c}0.310 \\
(0.311)\end{array}$ & & & & $\begin{array}{c}0.384 \\
(0.466)\end{array}$ & & & & \begin{tabular}{|c}
$-3.870^{\star \star \star}$ \\
$(1.385)$
\end{tabular} & & & & $\begin{array}{c}2.422^{\star \star *} \\
(0.738)\end{array}$ & & & \\
\hline hkpcj & $\begin{array}{l}1.811^{\star \star \star} \\
(0.317)\end{array}$ & & & & $\begin{array}{c}0.091 \\
(0.335)\end{array}$ & & & & $\begin{array}{l}-0.536^{\star} \\
(0.297)\end{array}$ & & & & \begin{tabular}{|c|}
$-4.431^{\star \star \star}$ \\
$(0.519)$
\end{tabular} & & & & $\begin{array}{c}1.652^{\star \star *} \\
(0.652)\end{array}$ & & & & $\begin{array}{c}-1.894 \\
(1.194)\end{array}$ & & & \\
\hline hkdist & & & $\begin{array}{c}0.002 \\
(0.054) \\
\end{array}$ & & & & $\begin{array}{c}-0.272^{\star \star \star} \\
(0.077) \\
\end{array}$ & & & & $\begin{array}{c}0.074 \\
(0.080) \\
\end{array}$ & & & & $\begin{array}{c}0.098 \\
(0.112) \\
\end{array}$ & & & & $\begin{array}{c}0.169 \\
(0.170) \\
\end{array}$ & & & & $\begin{array}{c}0.005 \\
(0.202) \\
\end{array}$ & \\
\hline disthkpci & & $\begin{array}{c}-2.864^{\star \star \star} \\
(0.279) \\
\end{array}$ & & & & $\begin{array}{l}-0.402 \\
(0.319) \\
\end{array}$ & & & & $\begin{array}{l}-0.135 \\
(0.451) \\
\end{array}$ & & & & $\begin{array}{c}0.482 \\
(1.007)\end{array}$ & & & & $\begin{array}{c}-4.595^{* \star \star} \\
(0.936)\end{array}$ & & & & $\begin{array}{l}3.291^{* *} \\
(1.461)\end{array}$ & & \\
\hline disthkpcj & & $\begin{array}{c}0.689^{\star \star \star} \\
(0.279)\end{array}$ & & & & $\begin{array}{c}-1.825^{\star \star \star} \\
(0.265)\end{array}$ & & & & $\begin{array}{l}-1.436^{*} \\
(0.753) \\
\end{array}$ & & & & $\begin{array}{c}-3.471^{\star \star \star} \\
(1.164)\end{array}$ & & & & $\begin{array}{c}1.561^{\star \star \star} \\
(0.611)\end{array}$ & & & & $\begin{array}{c}-3.750 * \star \star \\
(0.904)\end{array}$ & & \\
\hline dist*hkdist & & & & \begin{tabular}{|c|}
$-2.545^{\star \star \star}$ \\
$(0.133)$
\end{tabular} & & & & $\begin{array}{c}-2.129^{\star \star \star} \\
(0.183)\end{array}$ & & & & $\begin{array}{c}-0.402^{\star \star \star} \\
(0.150)\end{array}$ & & & & $\begin{array}{l}-0.824^{*} \\
(0.436)\end{array}$ & & & & $\begin{array}{l}0.752^{\star \star} \\
(0.369)\end{array}$ & & & & \begin{tabular}{|c|}
-0.329 \\
$(0.378)$
\end{tabular} \\
\hline dist & $\begin{array}{c}-2.378^{\star \star \star} \\
(0.215)\end{array}$ & & \begin{tabular}{c|}
$-2.528^{\star * \star}$ \\
$(0.184)$
\end{tabular} & & $\begin{array}{c}-2.082^{\star \star \star} \\
(0.318)\end{array}$ & & $\begin{array}{c}-3.051^{\star \star \star} \\
(0.282)\end{array}$ & & $\begin{array}{c}-1.353^{* \star *} \\
(0.373)\end{array}$ & & $\begin{array}{c}-1.085^{\star * *} \\
(0.286)\end{array}$ & & $\begin{array}{l}-1.147 \\
(0.809) \\
\end{array}$ & & $\begin{array}{c}-1.135^{\star *} \\
(0.491)\end{array}$ & & \begin{tabular}{|c|}
$-3.858^{\star \star \star}$ \\
$(0.648)$
\end{tabular} & & $\begin{array}{c}-1.799^{\star \star \star} \\
(0.302)\end{array}$ & & $\begin{array}{l}-0.350 \\
(0.650)\end{array}$ & & $\begin{array}{c}-1.558^{\star \star} \\
(0.808)\end{array}$ & \\
\hline border & $\begin{array}{c}-1.222^{\star \star \star} \\
(0.367)\end{array}$ & $\begin{array}{c}-0.782^{\star \star} \\
(0.325) \\
\end{array}$ & $\begin{array}{c}-1.403^{* \star \star} \\
(0.270)\end{array}$ & $\begin{array}{c}-1.365^{\star \star \star} \\
(0.259) \\
\end{array}$ & $\begin{array}{c}-0.174 \\
(0.451) \\
\end{array}$ & $\begin{array}{l}-0.191 \\
(0.361) \\
\end{array}$ & $\begin{array}{c}-1.699 * \star \star \\
(0.470)\end{array}$ & $\begin{array}{l}-0.414 \\
(0.350) \\
\end{array}$ & \begin{tabular}{|c}
$0.539 * \star \star$ \\
$(0.195)$ \\
\end{tabular} & $\begin{array}{l}0.491^{\star \star \star} \\
(0.194)\end{array}$ & $\begin{array}{l}0.531^{* *} \\
(0.225)\end{array}$ & $\begin{array}{c}0.603^{\star \star \star} \\
(0.226)\end{array}$ & & $\begin{array}{c}-0.121 \\
(0.318) \\
\end{array}$ & $\begin{array}{l}-0.190 \\
(0.382) \\
\end{array}$ & $\begin{array}{l}-0.115 \\
(0.435) \\
\end{array}$ & $\begin{array}{c}0.432 \\
(0.593) \\
\end{array}$ & $\begin{array}{c}0.510 \\
(0.632) \\
\end{array}$ & \begin{tabular}{|c}
$2.421 \star \star \star \star$ \\
$(0.524)$ \\
\end{tabular} & \begin{tabular}{c|}
$6.367^{* * *}$ \\
$(0.913)$ \\
\end{tabular} & \begin{tabular}{|c|}
$3.536^{* \star \star}$ \\
$(1.296)$ \\
\end{tabular} & $\begin{array}{c}3.124^{\star \star \star} \\
(1.184) \\
\end{array}$ & $\begin{array}{c}1.264 \\
(1.563) \\
\end{array}$ & \begin{tabular}{|c}
$2.422^{\star \star \star}$ \\
$(0.813)$
\end{tabular} \\
\hline EA & $\begin{array}{c}0.451^{* \star \star} \\
(0.175)\end{array}$ & $\begin{array}{c}0.459^{* \star \star} \\
(0.173)\end{array}$ & $\begin{array}{c}0.599^{\star \star \star} \\
(0.194) \\
\end{array}$ & $\begin{array}{c}0.601^{\star \star \star} \\
(0.194)\end{array}$ & $\begin{array}{l}0.736^{\star \star \star} \\
(0.188)\end{array}$ & $\begin{array}{c}0.730^{* \star *} \\
(0.192)\end{array}$ & $\begin{array}{c}0.911^{\star \star \star} \\
(0.223)\end{array}$ & $\begin{array}{c}0.851^{\star \star \star} \\
(0.221)\end{array}$ & & & & & & & & & \begin{tabular}{|c|}
$1.274^{\star \star \star}$ \\
$(0.405)$
\end{tabular} & $\begin{array}{l}1.117^{\star \star \star} \\
(0.437)\end{array}$ & \begin{tabular}{|c|}
$1.410^{\star \star \star}$ \\
$(0.419)$ \\
\end{tabular} & $\begin{array}{l}1.186^{* \star *} \\
(0.429)\end{array}$ & $\begin{array}{c}-0.120 \\
(0.350) \\
\end{array}$ & $\begin{array}{l}-0.019 \\
(0.343) \\
\end{array}$ & $\begin{array}{c}0.406 \\
(0.336) \\
\end{array}$ & $\begin{array}{c}0.217 \\
(0.304) \\
\end{array}$ \\
\hline EURO & & & & & & & & & $\begin{array}{c}0.061 \\
(0.114)\end{array}$ & $\begin{array}{l}0.204^{\star} \\
(0.109)\end{array}$ & $\begin{array}{l}0.272^{\star *} \\
(0.114)\end{array}$ & $\begin{array}{l}0.244^{\star *} \\
(0.105)\end{array}$ & $\begin{array}{l}-0.054 \\
(0.315)\end{array}$ & $\begin{array}{l}0.878^{\star} \\
(0.463)\end{array}$ & $\begin{array}{c}0.642 \\
(0.400)\end{array}$ & $\begin{array}{l}0.651^{*} \\
(0.398)\end{array}$ & & & & & & & & \\
\hline constant & $\begin{array}{c}-39.178^{\star \star \star} \\
(6.812) \\
\end{array}$ & $\begin{array}{c}-46.755^{\star \star \star} \\
(3.815) \\
\end{array}$ & \begin{tabular}{|c|}
$-27.498^{\star \star \star}$ \\
$(6.319)$
\end{tabular} & \begin{tabular}{|c|}
$-26.937 * \star * \star$ \\
$(2.541)$ \\
\end{tabular} & $\begin{array}{c}-56.1388^{\star \star \star} \\
(8.803)\end{array}$ & $\begin{array}{c}-49.532^{\star \star \star} \\
(3.423)\end{array}$ & $\begin{array}{c}-13.979^{* * *} \\
(5.068)\end{array}$ & \begin{tabular}{|c|}
$-32.582^{* \star *}$ \\
$(1.901)$ \\
\end{tabular} & $\begin{array}{c}-41.802^{\star \star \star} \\
(11.347) \\
\end{array}$ & \begin{tabular}{|c|}
$-24.704^{* * \star}$ \\
$(5.355)$ \\
\end{tabular} & $\begin{array}{c}-21.888^{* \star \star} \\
(5.249) \\
\end{array}$ & $\begin{array}{c}-32.819^{* * *} \\
(3.228) \\
\end{array}$ & $\begin{array}{c}- \\
171.294^{* \star *}\end{array}$ & $\begin{array}{c}-50.830^{* \star \star} \\
(7.416)\end{array}$ & $\begin{array}{c}-70.711^{\star * *} \\
(8.028) \\
\end{array}$ & $\begin{array}{c}-73.439^{* * \star} \\
(4.937) \\
\end{array}$ & \begin{tabular}{|c|}
- \\
$113.052^{* * *}$ \\
\end{tabular} & $\begin{array}{c}-73.027 * * \star \\
(8.396) \\
\end{array}$ & $\begin{array}{c}-32.896^{* \star *} \\
(6.576) \\
\end{array}$ & \begin{tabular}{|c|}
$-44.857 * \star *$ \\
$(8.764)$ \\
\end{tabular} & $\begin{array}{c}59.085 * \star * \\
(21.877) \\
\end{array}$ & $\begin{array}{c}-36.711^{\star \star \star \star} \\
(9.859) \\
\end{array}$ & \begin{tabular}{|c}
-5.951 \\
$(11.032)$ \\
\end{tabular} & \begin{tabular}{|l}
-10.514 \\
$(10.431)$ \\
\end{tabular} \\
\hline No obs & 900 & 900 & 900 & 900 & 869 & 869 & \begin{tabular}{|l|l|}
869 & \\
\end{tabular} & \begin{tabular}{|l|l|}
869 \\
\end{tabular} & 320 & 320 & 320 & 320 & 319 & 319 & 319 & 319 & 200 & 200 & 200 & 200 & 222 & 222 & 222 & \begin{tabular}{|l|}
222 \\
\end{tabular} \\
\hline $\mathrm{R2}$ & 0.9712 & 0.9718 & 0.9679 & 0.9677 & 0.939 & \begin{tabular}{|l|}
0.938 \\
\end{tabular} & \begin{tabular}{|l|}
0.934 \\
\end{tabular} & 0.926 & 0.990 & 0.990 & 0.988 & \begin{tabular}{|l|}
0.988 \\
\end{tabular} & 0.976 & \begin{tabular}{|l|}
0.952 \\
\end{tabular} & \begin{tabular}{|l|l|}
0.959 \\
\end{tabular} & \begin{tabular}{|l|l|}
0.959 \\
\end{tabular} & 0.912 & 0.9078 & 0.9015 & 0.8595 & 0.911 & 0.910 & 0.868 & 0.890 \\
\hline Wald Chi2 & $4072.88^{* \star *}$ & $3470.12^{\star \star *}$ & $1674.04 * \star x$ & $1876.18^{* \star *}$ & $2112.48^{\star \star \star}$ & $2001.87^{* \star *}$ & $1537.23^{\star \star \star \star}$ & $1044.2^{\star k \star}$ & $\mid 4930.12^{2 * *}$ & $5108.39^{* \star * \star}$ & $1822.89^{* * *}$ & $1527.77^{* \star *}$ & $1218.83^{* \star *}$ & $2792.47 * * *$ & $1653.99 * k *$ & $1338.15^{* \star *}$ & $922.74^{* \star *}$ & $807.04^{* * *}$ & $344.08^{\star * \star}$ & $170.13^{\star \star \star}$ & $327.82^{* * *}$ & $305.5^{* \star *}$ & $156.36^{\star \star \star}$ & $52.98^{\star \star \star}$ \\
\hline
\end{tabular}




\begin{tabular}{|c|c|c|c|c|c|c|c|c|c|c|c|c|c|c|c|c|c|c|c|c|c|c|c|c|}
\hline \multirow{3}{*}{$\begin{array}{l}\text { Wood } \\
\text { products }\end{array}$} & \multicolumn{8}{|c|}{ North-East } & \multicolumn{8}{|c|}{ North-South } & \multicolumn{8}{|c|}{ South-East } \\
\hline & \multicolumn{4}{|c|}{ Dependent Variable: Export Value } & \multicolumn{4}{|c|}{ Dependent Variable: Import Value } & \multicolumn{4}{|c|}{ Dependent Variable: Export Value } & \multicolumn{4}{|c|}{ Dependent Variable: Import Value } & \multicolumn{4}{|c|}{\begin{tabular}{|l|} 
Dependent Variable: Export Value \\
\end{tabular}} & \multicolumn{4}{|c|}{ Dependent Variable: Import Value } \\
\hline & Model 1 & Model 2 & Model 3 & Model 4 & Model 1 & 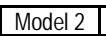 & Model 3 & Model 4 & Model 1 & 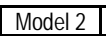 & \begin{tabular}{|l|} 
Model 3 \\
\end{tabular} & Model 4 & Model 1 & Model 2 & Model 3 & Model 4 & Model 1 & Model 2 & Model 3 & Model 4 & Model 1 & Model 2 & Model 3 & Model 4 \\
\hline popi & $\begin{array}{l}1.219^{\star \star \star} \\
(0.071)\end{array}$ & \begin{tabular}{|c|}
$1.145^{\star \star \star}$ \\
$(0.074)$
\end{tabular} & \begin{tabular}{c|}
$1.110^{* \star *}$ \\
$(0.064)$
\end{tabular} & \begin{tabular}{|c|}
$1.101^{\star \star \star}$ \\
$(0.073)$
\end{tabular} & \begin{tabular}{c|}
$1.187^{\star \star \star}$ \\
$(0.107)$
\end{tabular} & \begin{tabular}{|c|}
$1.220^{\star \star \star}$ \\
$(0.112)$
\end{tabular} & $\begin{array}{c}1.088^{\star \star \star} \\
(0.110)\end{array}$ & $\begin{array}{l}1.101^{\star \star \star} \\
(0.114)\end{array}$ & $\begin{array}{l}1.396^{* \star \star} \\
(0.136)\end{array}$ & $\begin{array}{c}1.339^{* \star \star} \\
(0.121)\end{array}$ & $\begin{array}{c}1.228^{\star \star \star} \\
(0.105)\end{array}$ & $\begin{array}{c}1.148^{\star \star \star} \\
(0.082)\end{array}$ & $\begin{array}{l}0.939^{* \star \star} \\
(0.064)\end{array}$ & \begin{tabular}{|c|}
$1.001^{* * \star}$ \\
$(0.033)$
\end{tabular} & \begin{tabular}{|c|}
$0.978^{\star \star \star}$ \\
$(0.070)$
\end{tabular} & \begin{tabular}{|c|}
$1.069^{\star * \star}$ \\
$(0.080)$
\end{tabular} & $\begin{array}{c}0.259 \\
(1.113)\end{array}$ & $\begin{array}{l}1.078^{\star \star \star} \\
(0.399)\end{array}$ & \begin{tabular}{|c|}
$1.728^{\star \star \star}$ \\
$(0.425)$
\end{tabular} & $\begin{array}{l}1.429^{\star \star \star *} \\
(0.508)\end{array}$ & $\begin{array}{c}0.498 \\
(0.518)\end{array}$ & \begin{tabular}{|c|}
$1.551^{* \star \star}$ \\
$(0.224)$
\end{tabular} & \begin{tabular}{|c|}
$2.165^{\star \star \star}$ \\
$(0.319)$
\end{tabular} & $\begin{array}{c}1.420^{\star \star \star \star} \\
(0.397)\end{array}$ \\
\hline popj & $\begin{array}{c}0.890^{\star k \star} \\
(0.135)\end{array}$ & \begin{tabular}{|c|}
$0.731^{* \star *}$ \\
$(0.141)$
\end{tabular} & \begin{tabular}{c|}
$0.597^{\star \star \star}$ \\
$(0.099)$
\end{tabular} & \begin{tabular}{|c|}
$0.584^{\star \star \star}$ \\
$(0.106)$
\end{tabular} & \begin{tabular}{|c|}
$1.044^{\star \star \star}$ \\
$(0.170)$
\end{tabular} & \begin{tabular}{|c|}
$1.078^{\star \star \star}$ \\
$(0.170)$
\end{tabular} & $\begin{array}{c}0.791^{\star \star \star} \\
(0.138)\end{array}$ & $\begin{array}{l}0.809^{\star \star \star} \\
(0.138)\end{array}$ & $\begin{array}{c}0.622 \\
(0.607)\end{array}$ & $\begin{array}{l}1.161^{\star \star} \\
(0.555)\end{array}$ & $\begin{array}{l}1.077^{\star \star \star} \\
(0.408)\end{array}$ & $\begin{array}{c}1.241^{* * *} \\
(0.261)\end{array}$ & $\begin{array}{c}-0.534 \\
(0.455)\end{array}$ & \begin{tabular}{|c|}
$0.762^{\star \star *}$ \\
$(0.219)$
\end{tabular} & \begin{tabular}{c|}
$1.633^{\star \star \star}$ \\
$(0.171)$
\end{tabular} & \begin{tabular}{|c|}
$1.888^{\star \star \star}$ \\
$(0.111)$
\end{tabular} & \begin{tabular}{|c|}
$0.768^{\star \star \star}$ \\
$(0.210)$
\end{tabular} & $\begin{array}{c}0.879^{\star \star \star} \\
(0.190)\end{array}$ & \begin{tabular}{|c|}
0.276 \\
$(0.210)$
\end{tabular} & $\begin{array}{c}-0.047 \\
(0.253)\end{array}$ & \begin{tabular}{|c|}
$1.211^{* k \star}$ \\
$(0.138)$
\end{tabular} & \begin{tabular}{|c|}
$1.329^{* \star \star}$ \\
$(0.163)$
\end{tabular} & \begin{tabular}{|c}
$0.715^{\star \star \star}$ \\
$(0.207)$
\end{tabular} & \begin{tabular}{|c|}
$0.559^{\star * \star}$ \\
$(0.210)$
\end{tabular} \\
\hline gdppci & $\begin{array}{l}1.753^{\star \star \star} \\
(0.343)\end{array}$ & & & & $\begin{array}{l}2.867^{7 * *} \\
(0.474)\end{array}$ & & & & $\begin{array}{c}3.344^{\star \star \star} \\
(0.564)\end{array}$ & & & & $\begin{array}{l}1.162^{\star \star} \\
(0.563)\end{array}$ & & & & $\begin{array}{c}7.394 \\
(4.577)\end{array}$ & & & & \begin{tabular}{|c}
$6.416^{\star \star \star}$ \\
$(1.938)$
\end{tabular} & & & \\
\hline gdppcj & $\begin{array}{c}0.510^{* \star *} \\
(0.183)\end{array}$ & & & & $\begin{array}{l}0.899^{\star * *} \\
(0.218)\end{array}$ & & & & $\begin{array}{l}2.867^{*} \\
(1.723)\end{array}$ & & & & $\begin{array}{l}7.733^{\star \star \star} \\
(1.812)\end{array}$ & & & & $\begin{array}{l}0.964^{\star \star \star} \\
(0.363)\end{array}$ & & & & $\begin{array}{c}1.488^{\star \star \star} \\
(0.162)\end{array}$ & & & \\
\hline gdppci*hkpci & & $\begin{array}{c}2.670^{\star \star \star} \\
(0.190)\end{array}$ & & & & \begin{tabular}{|c|}
$2.386^{\star \star \star}$ \\
$(0.269)$
\end{tabular} & & & & $\begin{array}{c}3.245^{\star \star \star} \\
(0.621)\end{array}$ & & & & $\begin{array}{c}0.620 \\
(0.604)\end{array}$ & & & & $\begin{array}{c}4.107^{\star \star \star} \\
(0.881)\end{array}$ & & & & $\begin{array}{c}1.933^{\star \star \star} \\
(0.636)\end{array}$ & & \\
\hline gdppcj*hkpcj & & $\begin{array}{c}0.1 .101^{\star \star \star} \\
(0.175)\end{array}$ & & & & $\begin{array}{l}0.925^{\star * \star} \\
(0.210)\end{array}$ & & & & $\begin{array}{c}-0.983 \\
(1.174)\end{array}$ & & & & $\begin{array}{l}1.478^{\star} \\
(0.872)\end{array}$ & & & & $\begin{array}{l}1.094^{\star \star \star} \\
(0.272)\end{array}$ & & & & $\begin{array}{l}1.643^{* \star *} \\
(0.148)\end{array}$ & & \\
\hline ecdist & & & $\begin{array}{c}1.335^{\star \star \star} \\
(0.276)\end{array}$ & & & & $\begin{array}{c}1.751^{\star \star \star} \\
(0.370)\end{array}$ & & & & \begin{tabular}{|c|}
$0.585^{\star \star \star}$ \\
$(0.215)$
\end{tabular} & & & & $\begin{array}{c}0.098 \\
(0.141)\end{array}$ & & & & $\begin{array}{l}-0.261 \\
(0.377)\end{array}$ & & & & $\begin{array}{c}-0.804^{* \star *} \\
(0.267)\end{array}$ & \\
\hline ecdistthkdist & & & & $\begin{array}{c}2.006^{\star \star \star} \\
(0.143)\end{array}$ & & & & $\begin{array}{c}1.320^{\star \star \star} \\
(0.204)\end{array}$ & & & & $\begin{array}{c}0.822^{\star \star \star} \\
(0.194)\end{array}$ & & & & $\begin{array}{c}0.093 \\
(0.150)\end{array}$ & & & & $\begin{array}{c}0.419 \\
(0.365) \\
\end{array}$ & & & & $\begin{array}{c}0.448 \\
(0.356) \\
\end{array}$ \\
\hline hkpci & $\begin{array}{c}1.170^{\star \star \star} \\
(0.207)\end{array}$ & & & & $\begin{array}{c}1.191^{\star \star \star} \\
(0.240)\end{array}$ & & & & $\begin{array}{c}0.127 \\
(0.330)\end{array}$ & & & & \begin{tabular}{|c|}
$0.654^{\star \star \star}$ \\
$(0.178)$
\end{tabular} & & & & $\begin{array}{c}0.904 \\
(0.802)\end{array}$ & & & & $\begin{array}{c}0.682 \\
(0.644)\end{array}$ & & & \\
\hline hkpcj & $\begin{array}{c}1.060^{\star \star \star} \\
(0.312)\end{array}$ & & & & $\begin{array}{l}0.814^{\star \star} \\
(0.395)\end{array}$ & & & & $\begin{array}{c}-0.230 \\
(0.363) \\
\end{array}$ & & & & $\begin{array}{c}-3.024^{\star \star \star} \\
(0.410)\end{array}$ & & & & $\begin{array}{l}1.336^{*} \\
(0.728)\end{array}$ & & & & $\begin{array}{c}0.286 \\
(0.680)\end{array}$ & & & \\
\hline hkdist & & & $\begin{array}{c}-0.034 \\
(0.041)\end{array}$ & & & & $\begin{array}{l}0.100^{*} \\
(0.053)\end{array}$ & & & & $\begin{array}{c}-0.003 \\
(0.038) \\
\end{array}$ & & & & $\begin{array}{l}0.112^{\star} \\
(0.067)\end{array}$ & & & & $\begin{array}{c}0.133 \\
(0.152) \\
\end{array}$ & & & & $\begin{array}{c}0.177 \\
(0.137) \\
\end{array}$ & \\
\hline distnkpci & & $\begin{array}{c}-1.976^{\star \star \star} \\
(0.230)\end{array}$ & & & & \begin{tabular}{c|}
$-1.045^{\star \star \star}$ \\
$(0.359)$
\end{tabular} & & & & \begin{tabular}{|c|}
$-2.833^{\star \star \star}$ \\
$(0.798)$
\end{tabular} & & & & $\begin{array}{c}1.054 \\
(0.712)\end{array}$ & & & & \begin{tabular}{c|}
$-2.733^{\star \star \star}$ \\
$(0.862)$
\end{tabular} & & & & $\begin{array}{c}-0.859 \\
(0.885)\end{array}$ & & \\
\hline distthkpcj & & $\begin{array}{l}-0.056 \\
(0.214)\end{array}$ & & & & $\begin{array}{c}-0.018 \\
(0.327)\end{array}$ & & & & $\begin{array}{c}1.321 \\
(1.205)\end{array}$ & & & & $\begin{array}{c}-3.603^{\star \star \star} \\
(0.682)\end{array}$ & & & & $\begin{array}{c}0.770 \\
(0.512)\end{array}$ & & & & $\begin{array}{c}-0.626 \\
(0.668)\end{array}$ & & \\
\hline dist*hkdist & & & & \begin{tabular}{|c|}
$-2.091^{\star \star \star}$ \\
$(0.157)$
\end{tabular} & & & & $\begin{array}{c}-1.197^{\star \star \star} \\
(0.230)\end{array}$ & & & & $\begin{array}{c}-0.805^{\star \star \star} \\
(0.205)\end{array}$ & & & & $\begin{array}{c}-0.034 \\
(0.176)\end{array}$ & & & & $\begin{array}{c}-0.711^{\star} \\
(0.397)\end{array}$ & & & & \begin{tabular}{|c|}
$-0.737^{\star \star \star}$ \\
$(0.281)$
\end{tabular} \\
\hline dist & $\begin{array}{c}-2.270^{\star \star \star} \\
(0.253)\end{array}$ & & \begin{tabular}{c|}
$-2.361^{\star \star \star}$ \\
$(0.235)$
\end{tabular} & & $\begin{array}{c}-0.822^{\star \star} \\
(0.408)\end{array}$ & & $\begin{array}{c}-0.984^{\star \star \star} \\
(0.347)\end{array}$ & & $\begin{array}{c}-0.325 \\
(0.589) \\
\end{array}$ & & $\begin{array}{c}-0.285 \\
(0.728) \\
\end{array}$ & & $\begin{array}{c}-2.119^{\star \star \star} \\
(0.210)\end{array}$ & & \begin{tabular}{c|}
$-1.111^{\star \star \star}$ \\
$(0.393)$
\end{tabular} & & $\begin{array}{c}-2.110^{\star \star \star} \\
(0.766)\end{array}$ & & $\begin{array}{c}2.627^{\star \star \star} \\
(0.545)\end{array}$ & & $\begin{array}{c}-1.543^{\star \star \star} \\
(0.388)\end{array}$ & & $\begin{array}{c}-2.784^{\star \star \star *} \\
(0.471)\end{array}$ & \\
\hline border & $\begin{array}{c}-0.657^{\star \star} \\
(0.293)\end{array}$ & $\begin{array}{c}-0.143 \\
(0.263)\end{array}$ & \begin{tabular}{c|}
$-0.909^{\star * \star}$ \\
$(0.309)$
\end{tabular} & $\begin{array}{c}0.005 \\
(0.187)\end{array}$ & $\begin{array}{c}1.962^{\star \star \star} \\
(0.695)\end{array}$ & $\begin{array}{c}1.477^{\star \star \star} \\
(0.476)\end{array}$ & $\begin{array}{c}1.545^{\star \star \star} \\
(0.598)\end{array}$ & $\begin{array}{c}1.111^{\star \star \star} \\
(0.363)\end{array}$ & $\begin{array}{c}0.181 \\
(0.571)\end{array}$ & $\begin{array}{c}0.143 \\
(0.493)\end{array}$ & $\begin{array}{l}0.901^{\star} \\
(0.510)\end{array}$ & $\begin{array}{c}0.443 \\
(0.351)\end{array}$ & $\begin{array}{l}0.476^{\star \star} \\
(0.204)\end{array}$ & \begin{tabular}{|c|}
$0.581^{\star \star \star}$ \\
$(0.214)$
\end{tabular} & \begin{tabular}{c|}
$0.952^{* \star \star}$ \\
$(0.245)$
\end{tabular} & \begin{tabular}{|c}
$1.261^{\star \star \star}$ \\
$(0.258)$
\end{tabular} & $\begin{array}{l}1.353^{\star} \\
(0.826)\end{array}$ & $\begin{array}{c}1.264 \\
(0.893)\end{array}$ & $\begin{array}{l}1.094^{\star *} \\
(0.471)\end{array}$ & $\begin{array}{l}4.028^{* \star *} \\
(0.715)\end{array}$ & $\begin{array}{l}2.02^{\star \star \star} \\
(0.649)\end{array}$ & \begin{tabular}{|c|}
$1.779^{\star \star \star}$ \\
$(0.661)$
\end{tabular} & $\begin{array}{c}0.198 \\
(0.539)\end{array}$ & $\begin{array}{c}3.080^{\star \star \star} \\
(0.573)\end{array}$ \\
\hline EA & $\begin{array}{l}0.554^{\star \star \star} \\
(0.179)\end{array}$ & $\begin{array}{c}0.577^{* \star *} \\
(0.176)\end{array}$ & $\begin{array}{c}0.710^{\star \star \star *} \\
(0.195)\end{array}$ & \begin{tabular}{|c|}
$0.642^{\star \star \star}$ \\
$(0.199)$
\end{tabular} & $\begin{array}{l}0.374^{\star \star \star} \\
(0.154)\end{array}$ & $\begin{array}{c}0.380^{* \star \star} \\
(0.155)\end{array}$ & $\begin{array}{c}0.463^{\star \star k} \\
(0.152)\end{array}$ & $\begin{array}{l}0.486^{\star \star \star} \\
(0.157)\end{array}$ & & & & & & & & & $\begin{array}{l}0.992^{\star \star \star} \\
(0.260)\end{array}$ & $\begin{array}{l}1.091^{\star \star \star} \\
(0.260)\end{array}$ & \begin{tabular}{|c}
$1.589 * \star \star$ \\
$(0.315)$ \\
\end{tabular} & $\begin{array}{l}1.157^{\star \star \star} \\
(0.288)\end{array}$ & $\begin{array}{l}0.353^{\star *} \\
(0.179)\end{array}$ & \begin{tabular}{|c|}
$0.518^{\star \star \star}$ \\
$(0.180)$ \\
\end{tabular} & $\begin{array}{c}1.034^{* \star *} \\
(0.209) \\
\end{array}$ & 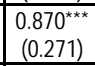 \\
\hline EURO & & & & & & & & & $\begin{array}{c}-0.106 \\
(0.185)\end{array}$ & $\begin{array}{c}0.088 \\
(0.198)\end{array}$ & $\begin{array}{c}0.173 \\
(0.220)\end{array}$ & $\begin{array}{c}0.156 \\
(0.222)\end{array}$ & $\begin{array}{c}-0.037 \\
(0.176)\end{array}$ & $\begin{array}{c}0.318 \\
(0.208)\end{array}$ & $\begin{array}{c}0.233 \\
(0.191)\end{array}$ & $\begin{array}{c}0.221 \\
(0.192)\end{array}$ & & & & & & & & \\
\hline constant & $\begin{array}{c}-20.383^{\star \star \star} \\
(7.890)\end{array}$ & $\begin{array}{c}-30.620^{* \star \star} \\
(4.225)\end{array}$ & $\begin{array}{c}-11.362^{\star \star \star} \\
(4.680)\end{array}$ & \begin{tabular}{|c|}
$-19.823^{* \star \star}$ \\
$(2.047)$
\end{tabular} & $\begin{array}{c}-46.035^{\star \star \star} \\
(9.423)\end{array}$ & \begin{tabular}{|c|}
$-40.088^{* \star \star}$ \\
$(4.840)$
\end{tabular} & $\begin{array}{c}-26.128^{\star \star \star \star} \\
(6.251)\end{array}$ & $\begin{array}{c}-20.710^{* \star \star} \\
(2.423)\end{array}$ & $\begin{array}{c}-76.522^{\star \star \star} \\
(14.571)\end{array}$ & \begin{tabular}{|c|}
$-35.874^{\star \star \star}$ \\
$(9.292)$
\end{tabular} & \begin{tabular}{|c|}
$-25.989 * \star$ \\
$(11.996)$
\end{tabular} & $\begin{array}{c}-25.462^{\star \star \star} \\
(4.203)\end{array}$ & \begin{tabular}{|c|}
$-67.929 * \star \star$ \\
$(12.317)$
\end{tabular} & $\begin{array}{c}-17.010^{* \star \star} \\
(3.129)\end{array}$ & $\begin{array}{c}-20.243^{\star \star \star} \\
(6.041)\end{array}$ & $\begin{array}{c}-34.343^{\star \star \star} \\
(2.876)\end{array}$ & \begin{tabular}{|c|}
$-60.786^{\star \star \star}$ \\
$(24.598)$
\end{tabular} & \begin{tabular}{|c|}
$-44.406^{* \star \star}$ \\
$(8.604)$
\end{tabular} & $\begin{array}{c}-0.196 \\
(11.356)\end{array}$ & $\begin{array}{c}-12.592 \\
(11.461)\end{array}$ & $\begin{array}{c}\mid-73.216^{* \star \star} \\
(10.629)\end{array}$ & $\begin{array}{c}-48.804^{\star \star \star} \\
(4.720)\end{array}$ & $\begin{array}{c}-6.892 \\
(4.943)\end{array}$ & $\begin{array}{c}-21.021^{\star \star \star} \\
(6.163)\end{array}$ \\
\hline No obs & 893 & 893 & 893 & \begin{tabular}{|c|}
893 \\
\end{tabular} & \begin{tabular}{|c|}
915 \\
\end{tabular} & \begin{tabular}{|l|l|}
915 \\
\end{tabular} & \begin{tabular}{|c|}
915 \\
\end{tabular} & \begin{tabular}{|l|l|}
915 \\
\end{tabular} & 320 & 320 & 320 & 320 & 321 & 321 & 321 & 321 & 212 & 212 & 212 & 212 & 217 & 217 & 217 & 217 \\
\hline & \begin{tabular}{|l}
0.9734 \\
\end{tabular} & 0.9739 & \begin{tabular}{l|l}
0.9724 \\
\end{tabular} & \begin{tabular}{|l|}
0.969 \\
\end{tabular} & \begin{tabular}{|l|l|}
0.974 \\
\end{tabular} & \begin{tabular}{|l|}
0.974 \\
\end{tabular} & \begin{tabular}{|l|}
0.966 \\
\end{tabular} & \begin{tabular}{|l|}
0.966 \\
\end{tabular} & \begin{tabular}{|l|}
0.979 \\
\end{tabular} & 0.978 & \begin{tabular}{|l|}
0.980 \\
\end{tabular} & \begin{tabular}{|l|}
0.983 \\
\end{tabular} & \begin{tabular}{|l|}
0.981 \\
\end{tabular} & \begin{tabular}{|l|}
0.982 \\
\end{tabular} & \begin{tabular}{|l|}
0.980 \\
\end{tabular} & 0.974 & 0.768 & \begin{tabular}{l|l}
0.7848 \\
\end{tabular} & 0.8268 & 0.8174 & \begin{tabular}{|l|}
0.945 \\
\end{tabular} & 0.951 & 0.947 & 0.923 \\
\hline Wald Chi2 & $2166.29^{* \star *}$ & $2431.36^{\star \star \star}$ & $1957.5^{\star \star \star}$ & $2598.88^{* \star * \star}$ & $2075.33^{\star \star \star *}$ & $2292.92^{2 * \star}$ & $1871.08^{\star \star \star \star}$ & $\mid 1879.7^{\star \star \star}$ & $1668.00^{* * *}$ & $1112.95^{* \star *}$ & $949.85^{\star \star \star}$ & $513.82^{\star \star \star}$ & $12770.07 *$ & $6329.83^{* \star *}$ & $5064.83^{* \star *}$ & $2138.20^{\star \star \star}$ & $283.05^{\star * \star}$ & $280.87^{\star \star *}$ & $136.84^{\star \star *}$ & \begin{tabular}{|l}
$96.38^{\star \star *}$ \\
\end{tabular} & $840.31^{\star \star \star}$ & $692.88^{\star \star \star *}$ & $387.07^{\star \star \star *}$ & $267.61^{\star \star \star}$ \\
\hline
\end{tabular}




\section{References}

Baldwin, R., Forslid, R., Haaland, J. and Midelfart-Knarvik, K. (2000), Eu Integration and Outsiders: A Simulation Study of Industrial Location, Norwegian School of Economics and Business Administration Discussion Paper, 02/2000.

Baldwin, R. E. (1994), Towards an Integrated Europe, Centre for Economic Policy Research, London.

Breuss, F. and Egger, P. (1999), How Reliable Are Estimations of East-West Trade Potentials Based on Cross-Section Gravity Analyses?, Empirica, 26, 81-94.

Buch, C. and Piazolo, D. (2000), Capital and Trade Flows in Europe and the Impact of Enlargement, Kiel Working Paper, 1001.

Davis, D. (2000), Understanding International Trade Patterns: Advances of the 1990s, Integration \& Trade, 4, 61-79.

Fidrmuc, J. (1998), Application of Gravity Models to Commodity Groups and Trade Projections between the Eu and the Ceec, mimeo, Institute for Advanced Studies, Vienna.

Hamilton, C. and Winters, A. (1992), Trade with Eastern Europe, Economic Policy, 77-116.

Havrylyshyn, O. and Pritchett, L. (1991), European Trade Patterns after the Transition, World Bank Working Paper, 748.

Krugman, P. (1991), Increasing Returns and Economic Geography, Journal of Political Economy, 99, 483499.

Krugman, P. (1993), The Hub Effect, or Threeness in Interregional Trade, In Theory, Policy and Dynamics in International Trade(Eds, Ethier, W., Helpman, E. and Neary, J. P.) CUP, Cambridge (UK), pp. 29-37.

Limao, N. and Venables, A. (2001), Infrastructure, Geographical Disadvantage, Transport Costs and Trade, World Bank Economic Review, 15, 451-79.

Linder, S. (1961), An Essay on Trade and Transformation, Wiley, New York.

Matyas, L. (1997), Proper Econometric Specification of the Gravity Model, World Economy, 20, 363-68.

Matyas, L. (1998), The Gravity Model: Some Econometric Considerations, World Economy, 21, 397-401.

Maurel, M. and Cheikbossian, G. (1998), The New Geography of Eastern European Trade, Kyklos, 51, 4571.

Melitz, J. (2001), Geography, Trade and Currency Union, CEPR DP 2987.

Nilsson, L. (2000), Trade Integration and the Eu Membership Criteria, European Journal of Political Economy, 16, 807-27.

Persson, T. (2001), Currency Unions and Trade: How Large Is the Treatment Effect?, Economic Policy, 16, 433-62.

Pratten, C. (1988), A Survey of Economies of Scale, In Research on the Cost of Non-Europe, Vol. 2 (Ed, CEC) CEC, Luxembourg.

Redding, S. and Venables, A. (2001), Economic Geography and International Inequality, CEP DP 495.

Rice, P., Stewart, M. and Venables, A. (2002), The Geography of Intraindustry Trade: Empirics, CEPR DP 3368.

Rose, A. (2000), One Money, One Market: The Effect of Common Currencies on Trade, Economic Policy, $15,7-46$.

Venables, A. (2001), Geography and International Inequalities: The Impact of New Technologies, CEP DP 507. 
Vittas, H. and Mauro, P. (1997), Potential Trade with Core and Periphery: Industry Differences in Trade

Patterns, In Europe's Economy Looks East(Ed, Black, S. W.) Cambridge University Press,

Cambridge (UK), pp. 67-99.

Winters, A. and Wang, Z. (1992), The Trading Potential of Eastern Europe, Journal of Economic Integration, 7, 113-36. 